\title{
Process Formulations and Curing Conditions that Affect Saltstone Properties
}

\author{
M.M. Reigel \\ B.R. Pickenheim \\ W.E. Daniel
}

September 2012 


\section{DISCLAIMER}

This work was prepared under an agreement with and funded by the U.S. Government. Neither the U.S. Government or its employees, nor any of its contractors, subcontractors or their employees, makes any express or implied:

1. warranty or assumes any legal liability for the accuracy, completeness, or for the use or results of such use of any information, product, or process disclosed; or

2. representation that such use or results of such use would not infringe privately owned rights; or

3. endorsement or recommendation of any specifically identified commercial product, process, or service.

Any views and opinions of authors expressed in this work do not necessarily state or reflect those of the United States Government, or its contractors, or subcontractors.

\section{Printed in the United States of America \\ Prepared for U.S. Department of Energy}


Keywords: Saltstone

Performance Assessment

Hydraulic Conductivity

Water to Premix Ratio

Retention: Permanent

\title{
Process Formulations and Curing Conditions that Affect Saltstone Properties
}

\author{
M.M. Reigel \\ B.R. Pickenheim \\ W.E. Daniel
}

September 2012

Savannah River National Laboratory Savannah River Nuclear Solutions, LLC Aiken, SC 29808

Prepared for the U.S. Department of Energy under contract number DE-AC09-08SR22470. 


\section{REVIEWS AND APPROVALS}

\section{AUTHORS:}

M.M. Reigel, Engineering Process Development

Date

B.R. Pickenheim, Engineering Process Development

Date

W.E. Daniel, Engineering Process Development

Date

TECHNICAL REVIEW:

C.A. Langton, Engineering Process Development

Date

R.E. Eibling, Engineering Process Development

Date

APPROVAL:

K.M. Fox, Manager

Date

Engineering Process Development

S.L. Marra, Manager

Date

Environmental \& Chemical Process Technology Research Programs

J.E. Occhipinti, Manager

Date

Waste Solidification Engineering

K.H. Rosenberger, Manager

Date

Closure \& Disposal Assessments 


\section{EXECUTIVE SUMMARY}

The Saltstone Production Facility (SPF) receives low level waste (LLW) salt solution from Tank 50H for treatment and disposal. Although Tank 50 receives transfers from multiple processes at the Savannah River Site (SRS), the primary influent is from the Actinide Removal Process/Modular Caustic Side Solvent Extraction Unit (ARP/MCU). At the SPF, the LLW is mixed with premix (a cementitious mixture of portland cement, blast furnace slag and Class $\mathrm{F}$ fly ash) in a Readco continuous mixer to produce fresh (uncured) saltstone that is transferred to the Saltstone Disposal Facility (SDF) for permanent disposition in the Saltstone Disposal Units (SDU) (previously referred to a vaults). Admixtures, if needed, are also added to the formulation to ensure the grout can be processed through the facility but not adversely affect the curing of saltstone in the SDU. Throughout processing operations, the mixer, grout hopper, grout pump, and piping to the SDU are flushed with water every 15 minutes to mitigate process upsets. However, this extra water (which also includes drain water, and sources other than the Tank 50 salt solution) is not accounted for in the water to premix (w/p) calculation for the saltstone formulation. Analysis of a continuous day of processing shows that during a routine operational flush, an instantaneous w/p ratio of 0.73 is being made. During nominal steady-state processing, the w/p ratio target is 0.59 or 0.60. Data from a typical (no setbacks or process upsets) processing day at the SPF were analyzed to calculate instantaneous and cumulative saltstone water to premix ratios over the given period of processing. A series of saltstone formulations were developed and analyzed based on these data. The fresh properties (set, bleed, flowability, viscosity, yield stress, and gel) and cured properties (porosity, density, compressive strength, hydraulic conductivity, and contaminant retention) of these formulations were analyzed.

The first objective of this study was to analyze saltstone fresh properties to determine the feasibility of reducing the formulation w/p ratio while varying the amount of extra water and admixtures used during processing at the SPF. The $8 \mathrm{wt} \%$ extra water in the formulation causes saltstone to generate more bleed water as it cures than the samples with $4 \mathrm{wt} \%$ extra water or salt solution since the water dilutes the salt solution molarity which delays the reaction of the slag and fly ash. Adding extra water to the formulations with w/p ratios of 0.58 or lower does not increase the set time past three days and the bleed water is reabsorbed after three days. Therefore, only considering the properties of bleed water and set time, it is feasible to process w/p ratios below 0.58 by adding extra water or admix. Adding Daratard to w/p ratios greater than 0.66 causes long set times and in some cases, standing bleed water after three days; therefore its use should be limited or avoided at these formulations.

However, the gel time is affected by the extra water, even at the low w/p ratios. Saltstone formulations with low w/p ratios (0.56 or lower) without any admixture or extra water, gel too quickly ( $<20 \mathrm{~min})$ to ensure reliable processing through the facility; however, if admix is used in these formulations, the gel time is extended into the acceptable range of $20-60$ minutes. Adding $8 \mathrm{wt} \%$ extra water to the low w/p formulations increases the gel time past 60 minutes. Therefore, for gel time it may be feasible to use Daratard to process low w/p ratios as long as the dosage is very well controlled and can remain at 0.05 wt \%. However, using $8 \mathrm{wt} \%$ extra water extends the gel time past the acceptable limits for these formulations. The vane rheology method for determining the gel time of a sample provides insight into the structure development of the sample; however it is difficult to distinguish the gel time from settling or other reactions based on the results obtained thus far. If this method is further developed, it could be less subjective than the pour test and provide more understanding into the hydration and structure development of fresh saltstone.

Based on the fresh property data presented in this report, mixes with w/p ratios in the range of $0.57-0.66$ formulated with $4 \mathrm{wt} \%$ extra water or salt solution only, produce fresh saltstone grout that satisfies acceptance criteria for set time, bleed, gel, and rheology. All of the formulations with 8 wt \% extra water 
or formulations with w/p ratios above 0.65 that include Daratard, have fresh properties outside the acceptance criteria.

The second part of this study was to provide information for understanding the impact of curing conditions (cure temperature, relative humidity $(\mathrm{RH})$ ) and processing formulation on the performance properties of cured saltstone. Samples were cured under profiles based on temperature data from cell K and cell F in SDU 4. Half of the samples were kept under saturated conditions by adding liquid on top of the grout to maintain complete saturation. The other half had the grout surface exposed to the humid environment. Based on the results of this study, the relative humidity of the curing environment has the most impact on the performance (cured) properties of saltstone. If the drying of the sample is eliminated or at least minimized, higher cure temperatures can be beneficial for saltstone due to increased reaction rates, formation of denser hydration products, and reduction in porosity.

The final w/p ratio of the formulation does affect the density, porosity, and compressive strength of the cured saltstone. The saltstone formulations with $0.59 \mathrm{w} / \mathrm{p}$ ratios and lower had higher densities, lower porosities, and higher compressive strength than samples formulated at a higher w/p ratio. There is a general trend that the samples formulated at high w/p ratios (0.67 and higher) have the lowest density, highest porosity and lowest strength. However, compared to data from previous studies, the density, porosity, and compressive strength of saltstone are more controlled by curing in a high humidity environment rather than the w/p ratio of the saltstone formulation. The Leachability index for $\mathrm{Na}, \mathrm{NO}_{3}{ }^{-}$ and $\mathrm{NO}_{2}^{-}$was calculated for the cured samples using the ANS/ANSI 16.1 standard. Based on the formulations tested in this study, the initial formulation of the samples did not have an effect on the rate at which contaminants are released from the saltstone.

Samples cured for 28 days in controlled humidity environments under temperature profiles up to 55 and $80^{\circ} \mathrm{C}$ had hydraulic conductivities of $4.5 \mathrm{E}-8$ to $4.3 \mathrm{E}-10 \mathrm{~cm} / \mathrm{s}$. On average, the cell $\mathrm{K}$ samples had slightly higher hydraulic conductivities for samples at higher w/p ratios than the cell F samples; however, the majority of the samples have hydraulic conductivities within the range of E-9 or E-10 cm/s. Of the 72 samples analyzed, only three samples had hydraulic conductivities on the order of $2.8 \mathrm{E}-7 \mathrm{~cm} / \mathrm{s}$. In a previous study, samples cured isothermally in an uncontrolled environment had hydraulic conductivities ranging from $1.04 \mathrm{E}-9$ to $1.90 \mathrm{E}-6 \mathrm{~cm} / \mathrm{s}$, with the majority of the $60{ }^{\circ} \mathrm{C}$ samples having hydraulic conductivities greater than $1.0 \mathrm{E}-7 \mathrm{~cm} / \mathrm{s}$. Comparing the results presented in this study to the results from the previous study, the curing conditions have a greater effect on the hydraulic conductivity of saltstone than the w/p ratio. The saltstone in the current study was cured in a high humidity environment which allowed the microstructure to develop without being dehydrated, reducing the formation of microcracks. Therefore, the combination of curing saltstone in a saturated or high humidity environment and under a ramped temperature profile results in slower hydraulic conductivities than saltstone dried out during curing and cured at high isothermal temperatures. 


\section{TABLE OF CONTENTS}

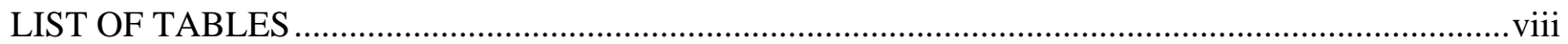

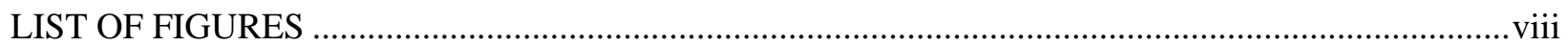

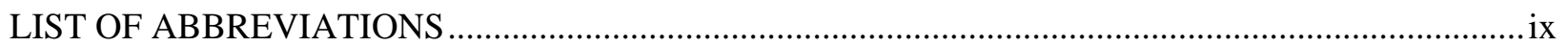

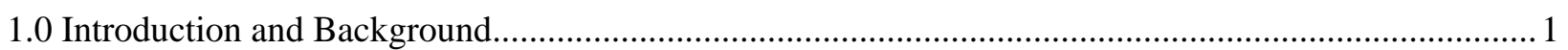

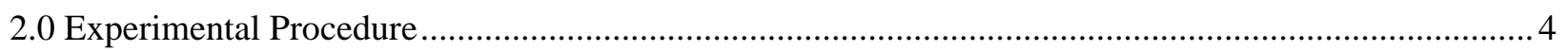

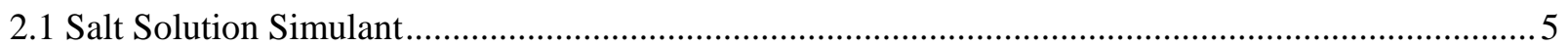

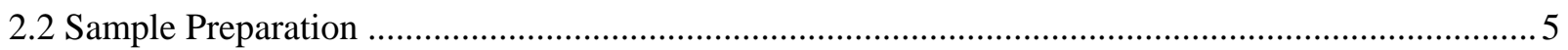

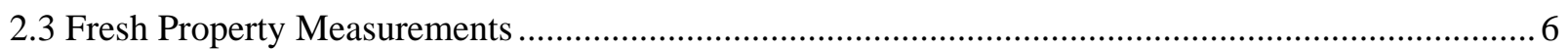

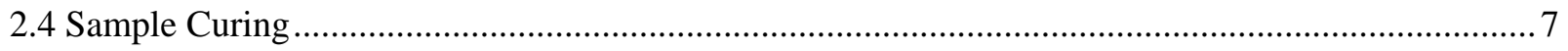

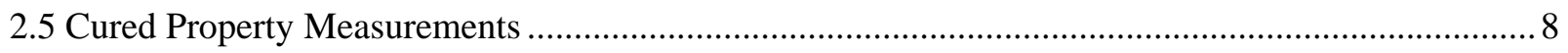

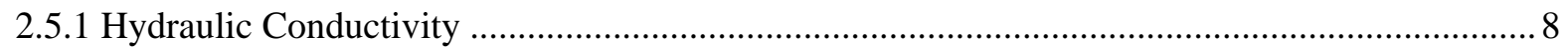

2.5.2 Compressive strength, porosity, cured density …................................................................. 9

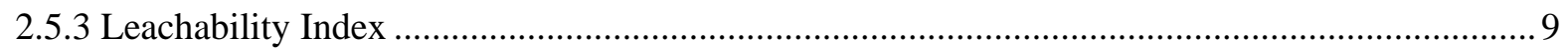

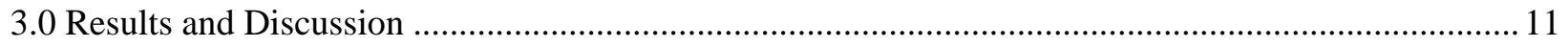

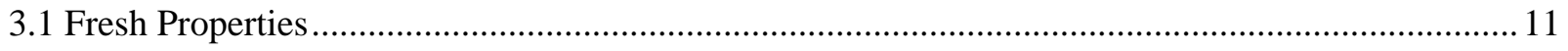

3.1.1 Fresh Density, Heat of Hydration, Flowability, Bleed and Set Time ...................................... 11

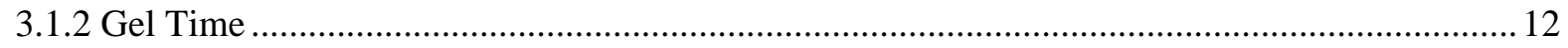

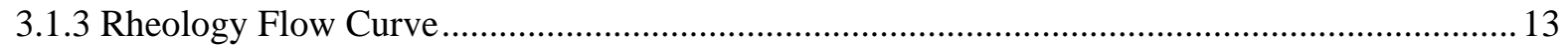

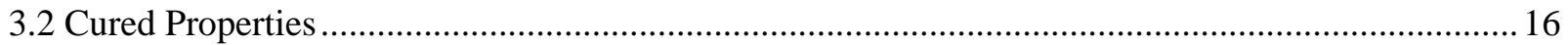

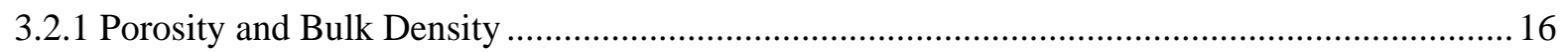

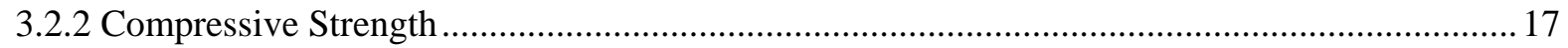

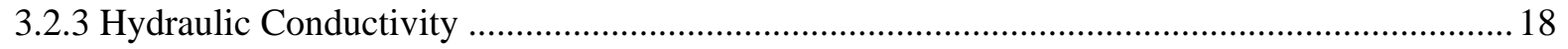

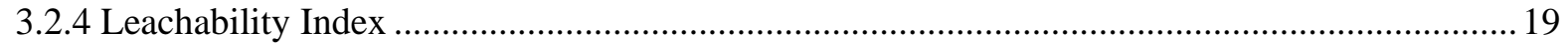

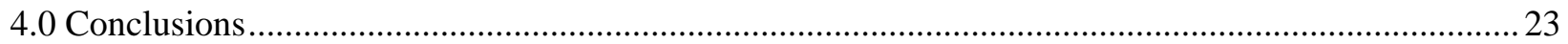

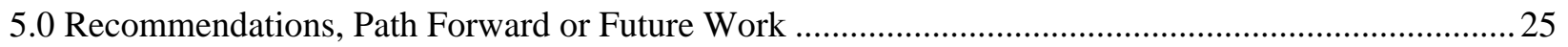

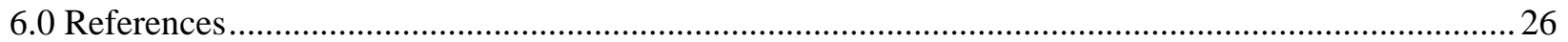




\section{LIST OF TABLES}

Table 2-1. Experimental design for saltstone mixes tested ...................................................................... 4

Table 2-2. Composition of mid-aluminate ARP/MCU salt solution simulant ........................................... 5

Table 2-3. Saltstone premix materials................................................................................................. 5

Table 2-4. Sample size and containers for specific property analyses................................................. 6

Table 2-5. Cut Saltstone sample dimensions and calculations for surface area and leachant volume........ 10

Table 3-1. Fresh density, flowability, set, bleed, and heat of hydration for all mixes .............................. 11

Table 3-2. Comparison of gel time measurements for all mixes ........................................................... 13

Table 3-3. Yield stress and plastic viscosity results for all mixes from lowest to highest......................... 14

Table 3-4. Bulk density and porosity of samples, listed from lowest to highest final w/p ratio, cured under

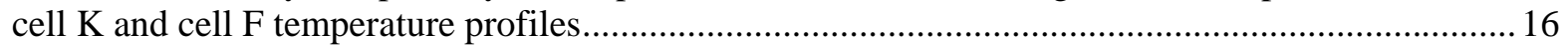

Table 3-5. Compressive strength of samples, listed from lowest to highest final w/p ratio, cured under cell $\mathrm{K}$ and cell $\mathrm{F}$ temperature profiles ................................................................................................ 18

Table 3-6. Hydraulic conductivity of samples, listed from lowest to highest final w/p ratio, cured under

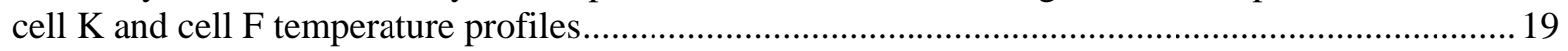

Table 3-7. Leachability Index of $\mathrm{Cr}$ (excluding and *including $\mathrm{Cr}$ in Pre-mix) for saltstone cured under

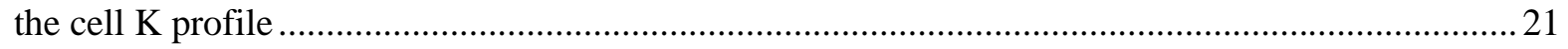

Table 3-8. Leachability Index of Na for saltstone cured under the cell K profile................................... 21

Table 3-9. Leachability Index of $\mathrm{NO}_{3}{ }^{-}$and $\mathrm{NO}_{2}{ }^{-}$for saltstone cured under the cell $\mathrm{K}$ profile.................. 22

\section{LIST OF FIGURES}

Figure 1-1. Simplified Saltstone Facility process flow diagram ........................................................... 1

Figure 2-1. Modified cell F and cell K curing profiles ................................................................. 8

Figure 3-1. Flow curves (decreasing shear rate) for samples starting at $0.59 \mathrm{w} / \mathrm{p}$ and adding admixture or

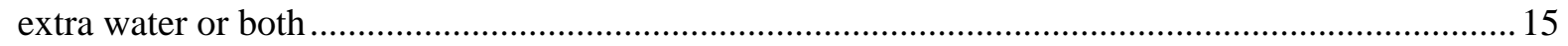

Figure 3-2. Flow curves (decreasing shear rate) for all mixes made without admix or extra water ........... 15 


\section{LIST OF ABBREVIATIONS}

\begin{tabular}{|c|c|}
\hline ANS & American Nuclear Society \\
\hline ANSI & American National Standards Institute \\
\hline ARP & Actinide Removal Process \\
\hline ASTM & American Society for Testing and Materials \\
\hline C\&WDA & Closure and Waste Disposal Authority \\
\hline gpm & Gallons per minute \\
\hline $\mathrm{HOH}$ & Heat of Hydration \\
\hline IC & Ion Chromatography \\
\hline ICP-ES & Inductively Coupled Plasma Emission Spectroscopy \\
\hline LLW & Low Level Waste \\
\hline MCU & Modular Caustic Side Solvent Extraction Unit \\
\hline $\mathrm{mL}$ & milliliters \\
\hline PA & Performance Assessment \\
\hline Psi & Pounds per square inch \\
\hline RH & Relative Humidity \\
\hline s & second \\
\hline SDF & Saltstone Disposal Facility \\
\hline SDU & Saltstone Disposal Unit \\
\hline SPF & Saltstone Production Facility \\
\hline SRNL & Savannah River National Laboratory \\
\hline SRS & Savannah River Site \\
\hline TTQAP & Task Technical and Quality Assurance Plan \\
\hline TTR & Technical Task Request \\
\hline $\mathrm{w} / \mathrm{p}$ & Water to premix \\
\hline WSE & Waste Solidification Engineering \\
\hline wt \% & Weight percent \\
\hline
\end{tabular}




\subsection{Introduction and Background}

The Saltstone Facility at the Savannah River Site (SRS) is comprised of two facilities, the Saltstone Production Facility (SPF) and the Saltstone Disposal Facility (SDF). The SPF receives low level waste (LLW) salt solution from Tank $50 \mathrm{H}$ for treatment. Although Tank 50 receives transfers from multiple processes at SRS, the primary influent is from the Actinide Removal Process/Modular Caustic Side Solvent Extraction Unit (ARP/MCU). At the SPF, the LLW is mixed with premix (a cementitious mixture of portland cement, blast furnace slag and Class F fly ash) in a Readco continuous mixer to produce fresh (uncured) saltstone that is transferred to the Saltstone Disposal Facility (SDF) for permanent disposition in a Saltstone Disposal Unit (SDU) (previously referred to as a vault). Admixtures, if needed, ${ }^{1-3}$ are also added to the formulation to ensure the grout can be processed through the facility but not adversely affect the curing of saltstone in the SDU. Figure 1-1 shows a simplified process flow diagram for the entire Saltstone Facility.

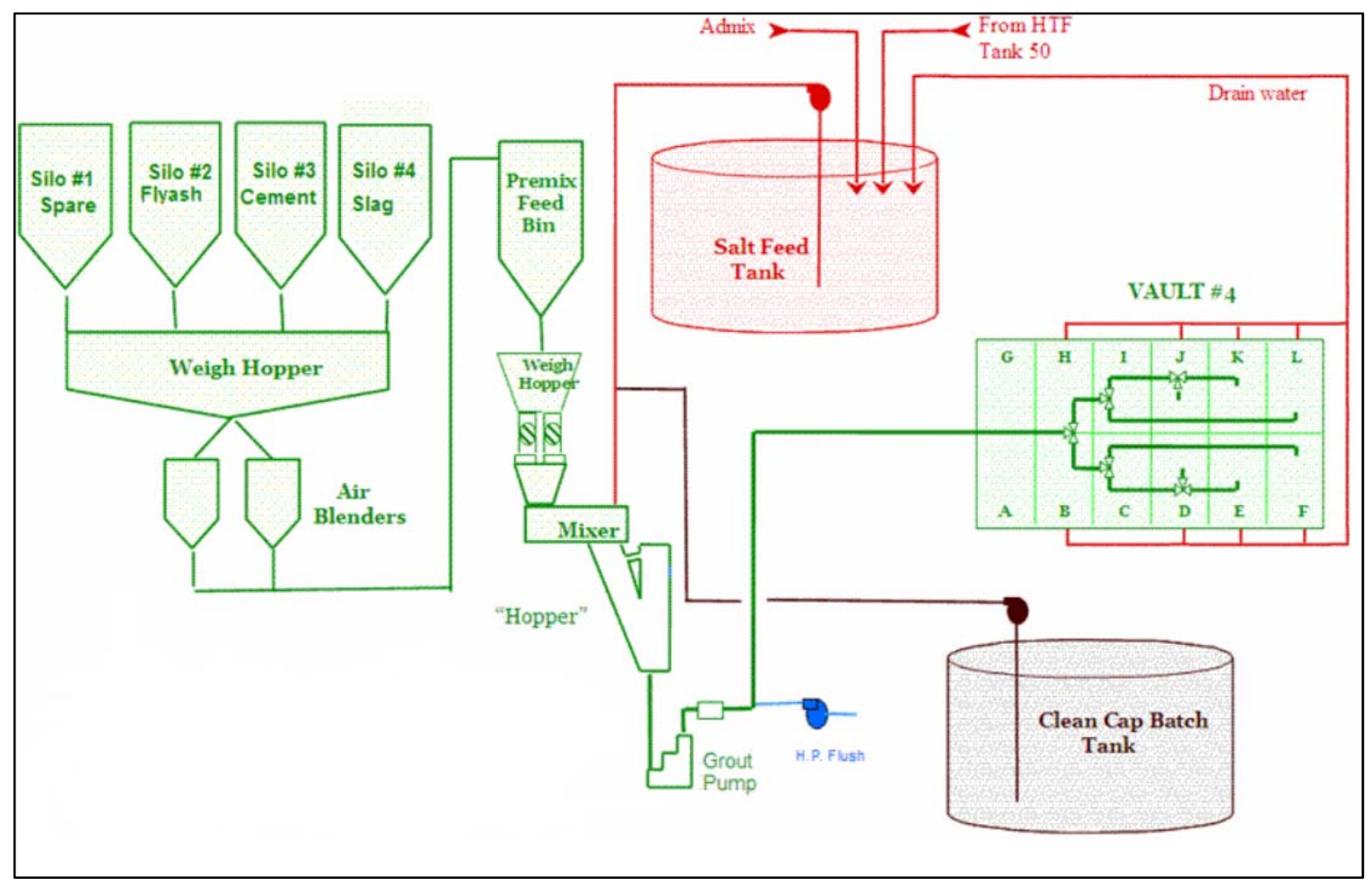

Figure 1-1. Simplified Saltstone Facility process flow diagram

Throughout processing operations, the mixer, grout hopper, grout pump, and piping to the SDU are flushed with water every 15 minutes to mitigate process upsets. However, this extra water is not accounted for in the water to premix (w/p) calculation for the saltstone formulation. Analysis of a continuous day of processing shows that during a routine operational flush, an instantaneous w/p ratio of 0.73 is being made. During nominal steady-state processing, the w/p ratio target is 0.59 or 0.60 . Previous testing has shown that saltstone formulated at a higher $\mathrm{w} / \mathrm{p}$ ratio has longer gel and set times, more bleed water generated, and generally poor performance properties compared to saltstone made at w/p ratios of 0.6 or lower. $^{4-8}$ The yield stress and plastic viscosity of fresh saltstone, properties which are indicative of the flowability and thickness of the slurry, are dependent on the final w/p ratio of the formulation. ${ }^{9}$

* Using PI ProcessBook and PI DataLink to analyze instantaneous and cumulative w/p ratios throughout processing on Nov. 23, 2011. 
Adding Daratard or extra water or both to the initial saltstone formulation to increase the w/p ratio lowers the yield stress and plastic viscosity of that mixture. Saltstone formulations with extra water or admixtures often have longer gel times than samples at lower w/p ratios. ${ }^{2}$

Admixtures, specifically Daratard-17, a set retarder and long range water reducer, have a significant impact on the fresh and cured properties of saltstone. Historically, Daratard-17 has been added to a saltstone formulation to extend the gel time past 20 minutes, improve flowability, and to optimize processing. ${ }^{10-12}$ Recent studies have shown that it causes a significant amount of drain water to be returned from the SDU, especially at higher w/p ratios ${ }^{13}$ which dilutes the Tank 50 material held in the Salt Feed Tank (SFT) prior to being processed (Figure 1-1). ${ }^{14}$ In addition, the extra drain water causes an increased amount of cementitious solids ${ }^{15}$ to pass through the sheet drain that lines the inside of the SDU and plug the drain water return lines. ${ }^{13}$ This buildup of cementious material causes failure of the drain water return system and associated equipment, and causes delays in processing material from Tank $50 \mathrm{H}^{16}$ Therefore, the feasibility of altering the flowsheet to reduce the w/p ratio while varying the Daratard concentration and maintaining the current operational strategy (flushing sequence) is investigated in this report as requested in the Technical Task Request (TTR) from Waste Solidification Engineering (WSE). ${ }^{16}$ As described in the Task Technical and Quality Assurance Plan (TTQAP), the fresh properties (density, rheology, flowability, etc.) of these grout mixes are evaluated to facilitate development of acceptance criteria for saltstone to ensure processability through the SPF. ${ }^{17}$

Static gel time has been used to estimate the amount of time available for recovery in the event of a process upset. It is an indication of the maximum amount of time the pumps could be inoperable before the slurry developed enough structure to prevent fluid response to pressure. ${ }^{11}$ Static gel time has also been used along with operating experience to estimate saltstone flowability in the SDUs. The shorter the gel time, the less flow achieved in the SDUs. ${ }^{11}$ The traditional pour test provides a gel time of the fresh grout; however, the rate the sample is poured, disturbing the sample prior to analysis, and the judgment of the researcher all factor into the final determination of the gel time. Replacing the pour test with a less subjective measurement such as monitoring the development of structure in the saltstone by measuring shear stress using vane rheology would be a more definitive method that could be related to processing of grout through the SPF.

In a separate TTR, Closure and Waste Disposal Authority (C\&WDA) requested the cured properties of the saltstone formulations requested by WSE be analyzed to further define the SPF/SDF operating conditions required to meet the materials performance properties used in the SDF Performance Assessment (PA). ${ }^{18}$ As a continuation of previous work, ${ }^{8}$ samples were cured under a temperature profile rather than cured isothermally. As described in the TTQAP, historical data from SDU 4 were used as a basis for the temperature profile; however it is important to note that temperatures recorded in previous disposal units vary due to many factors including processing strategy and saltstone formulation. The temperatures that will be recorded in future SDUs will vary from those in SDU 4 due to pour strategy, formulation, and other factors. The intention of this study was to trend saltstone performance properties as a function of curing conditions (relative humidity, temperature) rather than provide information on the performance of material residing in SDU 4 or previous disposal units. Since field conditions vary in the disposal units depending on pour strategy, etc., two curing conditions were investigated. The first was curing saltstone under a defined temperature profile with the surface exposed to a humid environment. The second was saltstone cured under the sample temperature profile while keeping the surface covered with liquid to maintain saturated conditions as described in the PA. ${ }^{19}$ The cured properties of these samples are compared to results from a previous study ${ }^{8}$ where samples were cured under the same temperature profile in an environment with uncontrolled humidity.

The objective of this report is twofold: first, analyze saltstone fresh properties to determine the feasibility of reducing the formulation w/p ratio while varying the amount of extra water and admixtures used during 
processing; and second, provide information for understanding the impact of curing conditions (cure temperature, relative humidity (RH)) and processing formulation (w/p, extra water, admixtures) on the performance properties (hydraulic conductivity, porosity, density, contaminant retention) of cured saltstone. 


\subsection{Experimental Procedure}

Data from a typical (no setbacks or process upsets) processing day at the SPF were analyzed to determine the average amount of extra water added to the system (Appendix A). Extra water is defined for this work as the water from flushes, drain water, and sources other than the Tank 50 salt solution. The data were used to calculate instantaneous and cumulative w/p ratios over the given period of processing. Both points were tested to provide snapshots of actual conditions at a given time in the facility.

The w/p ratio, amount of extra water, and admixture dosage are the formulation variables. The premix composition and the salt solution chemistry were held constant. The test matrix is listed in Table 2-1. Cured properties were measured on selected samples that encompass the ranges of w/p ratios investigated in this study. The starting $\mathrm{w} / \mathrm{p}$ was selected by assuming that only the LLW salt solution is being processed with premix to make saltstone slurry. The baseline formulation $0.59 \mathrm{w} / \mathrm{p}$ ratio with no admix or extra water (WP001) since this is how the SPF has been processing since the third quarter of 2011. The extra water added is the total calculated amount of water added during a full day of processing (8 wt \% of the LLW processed) or half of that amount (4 wt \%). The final w/p ratio is calculated after the extra water is added to the formulation. The amount of admix added is an average of admix dosage to the saltstone formulations from 2008 - 2010 (approximately $0.08 \mathrm{gpm}$ in the SPF). ${ }^{20,21}$ The formulations selected for cured property measurements are representative of the range of starting and final w/p ratios analyzed in this report.

Table 2-1. Experimental design for saltstone mixes tested

\begin{tabular}{|c|c|c|c|c|c|}
\hline Sample & $\begin{array}{c}\text { Starting } \\
\mathbf{w} / \mathbf{p} \\
\end{array}$ & $\begin{array}{c}\begin{array}{c}\text { Extra Water } \\
(w t \%)\end{array} \\
\end{array}$ & $\begin{array}{c}\text { Final } \\
\mathbf{w} / \mathbf{p} \\
\end{array}$ & $\begin{array}{l}\text { Admix } \\
\text { (wt \%) }\end{array}$ & $\begin{array}{c}\text { Measure Cured } \\
\text { Properties? } \\
\end{array}$ \\
\hline WP001 & 0.59 & 0 & 0.59 & 0.00 & $\mathrm{Y}$ \\
\hline WP002 & 0.56 & 0 & 0.56 & 0.00 & $\mathrm{~N}$ \\
\hline WP003 & 0.67 & 0 & 0.67 & 0.00 & $\mathrm{Y}$ \\
\hline WP004 & 0.59 & 0 & 0.59 & 0.05 & $\mathrm{~N}$ \\
\hline WP005 & 0.56 & 8 & 0.70 & 0.05 & $\mathrm{Y}$ \\
\hline WP006 & 0.52 & 0 & 0.52 & 0.00 & $\mathrm{~N}$ \\
\hline WP007 & 0.53 & 0 & 0.53 & 0.05 & $\mathrm{~N}$ \\
\hline WP008 & 0.55 & 4 & 0.62 & 0.00 & $\mathrm{~N}$ \\
\hline WP009 & 0.69 & 0 & 0.69 & 0.05 & $\mathrm{~N}$ \\
\hline WP010 & 0.58 & 8 & 0.72 & 0.05 & $\mathrm{Y}$ \\
\hline WP011 & 0.57 & 4 & 0.64 & 0.00 & $\mathrm{Y}$ \\
\hline WP012 & 0.54 & 0 & 0.54 & 0.05 & $\mathrm{~N}$ \\
\hline WP013 & 0.54 & 8 & 0.68 & 0.00 & $\mathrm{~N}$ \\
\hline WP014 & 0.55 & 0 & 0.55 & 0.00 & $\mathrm{Y}$ \\
\hline WP015 & 0.61 & 0 & 0.61 & 0.00 & $\mathrm{~N}$ \\
\hline WP016 & 0.58 & 0 & 0.58 & 0.05 & $\mathrm{~N}$ \\
\hline WP017 & 0.57 & 0 & 0.57 & 0.05 & $\mathrm{~N}$ \\
\hline WP018 & 0.73 & 0 & 0.73 & 0.00 & $\mathrm{Y}$ \\
\hline WP019 & 0.71 & 0 & 0.71 & 0.05 & $\mathrm{~N}$ \\
\hline WP020 & 0.63 & 0 & 0.63 & 0.00 & $\mathrm{~N}$ \\
\hline WP021 & 0.53 & 4 & 0.60 & 0.05 & $\mathrm{Y}$ \\
\hline WP022 & 0.65 & 0 & 0.65 & 0.05 & $\mathrm{~N}$ \\
\hline WP023 & 0.51 & 0 & 0.51 & 0.00 & $\mathrm{Y}$ \\
\hline WP024 & 0.59 & 4 & 0.66 & 0.05 & $\mathrm{~N}$ \\
\hline WP025 & 0.59 & 8 & 0.74 & 0.00 & $\mathrm{~N}$ \\
\hline
\end{tabular}




\section{1 $\underline{\text { Salt Solution Simulant }}$}

The mid-aluminate molarity salt solution (Table 2-2) is used in this task since its composition is comparable to what is currently being processed from Tank $50 \mathrm{H}$ and cured property results from previous studies can be compared to results from this report. ${ }^{8,22}$ The salt solution was spiked with chromium (300 $\mathrm{mg} / \mathrm{L}$ ) to facilitate contaminant retention testing of cured samples.

Table 2-2. Composition of mid-aluminate ARP/MCU salt solution simulant

\begin{tabular}{|c|c|c|}
\hline \multirow[b]{2}{*}{ Compound } & \multicolumn{2}{|c|}{ Mid Aluminate } \\
\hline & $\begin{array}{c}\text { Molarity } \\
{[\mathrm{mol} / \mathrm{L}]}\end{array}$ & $\begin{array}{c}\text { Molecular } \\
\text { Weight } \\
\text { [g/mol] } \\
\end{array}$ \\
\hline $50 \%$ by Weight $\mathrm{NaOH}$ & 2.460 & 40.00 \\
\hline $\mathrm{NaNO}_{3}$ & 1.865 & 84.99 \\
\hline $\mathrm{NaNO}_{2}$ & 0.550 & 68.99 \\
\hline $\mathrm{Na}_{2} \mathrm{CO}_{3}$ & 0.176 & 105.99 \\
\hline $\mathrm{Na}_{2} \mathrm{SO}_{4}$ & 0.059 & 142.04 \\
\hline Aluminum Nitrate $\left(9 \mathrm{H}_{2} \mathrm{O}\right)$ & 0.165 & 375.13 \\
\hline Sodium Phosphate $\left(12 \mathrm{H}_{2} \mathrm{O}\right)$ & 0.012 & 380.12 \\
\hline Total Salt mass (g) & \multicolumn{2}{|c|}{359.06} \\
\hline Total sodium Molarity & \multicolumn{2}{|c|}{5.38} \\
\hline
\end{tabular}

\subsection{Sample Preparation}

The nominal premix distribution used in this testing is 45 wt \% slag, 45 wt \% thermally beneficiated Class F fly ash, and $10 \mathrm{wt} \%$ portland cement. The premix materials (Table 2-3) were received in five gallon containers from the vendors during delivery of the bulk materials to the SPF. The premix materials were stored such that the exposure to humid air and hydration was limited prior to use.

Table 2-3. Saltstone premix materials

\begin{tabular}{||c|c|c||}
\hline Material & Category & Vendor \\
\hline Portland Cement & ASTM C 150/ C 150M-11 & Holcim \\
\hline Blast Furnace Slag & ASTM C 989-10 & Holcim \\
\hline Fly Ash & ASTM C 618-08a & SEFA \\
\hline
\end{tabular}

The salt solution, premix, and admix materials were mixed for approximately three minutes using a paddle blade mixer. The mixing was paused for approximately five seconds after 30 seconds of mixing to allow entrained air to escape from the grout. All mixes included ACP-3183 (previously called Q2-3183A), an antifoam admixture, at a dose of $0.03 \mathrm{wt} \%$, since it is included during daily processing at the SPF. Daratard-17 was added to selected mixes (Table 2-1) at the specified dosage of $0.05 \mathrm{wt} \%$. All admixture dosages are on a wt \% basis of the premix in the formulation. The admixtures were added to the salt solution first and then the dry feeds were added. After mixing was complete, the fresh grout was poured into sample molds and cups for property testing. Table 2-4 lists the approximate sample size for each analysis performed in this study. 
Table 2-4. Sample size and containers for specific property analyses

\begin{tabular}{|c|c|c|}
\hline $\begin{array}{c}\text { Property or Analysis } \\
\text { Method }\end{array}$ & Sample Container & $\begin{array}{c}\text { Approximate } \\
\text { Sample Mass }\end{array}$ \\
\hline \hline Bleed water & $1 \times 4$ inch vials & 75 grams \\
\hline Set & $1 \times 4$ inch vials & 50 grams \\
\hline Fresh density & $1 \times 4$ inch vials & 15 grams \\
\hline Gel time & $1 \times 4$ inch vials & 50 grams \\
\hline Rheology Flow Curve & Rheology cup & 100 grams \\
\hline Vane rheology & Rheology cup & 300 grams \\
\hline Flow Cone & $2 \times 4$ inch cylinder & 150 grams \\
\hline Heat of Hydration & 15 mL vial & 7 grams \\
\hline Compression & $3 \times 6$ inch cylinder & 1200 grams \\
\hline Bulk Density & $3 \times 6$ inch cylinder & 1200 grams \\
\hline Hydraulic Conductivity & $3 \times 6$ inch cylinder & 1200 grams \\
\hline Leachability Index & $1 \times 4$ inch vials & 130 grams \\
\hline Porosity & Not applicable & 100 grams \\
\hline
\end{tabular}

\subsection{Fresh Property Measurements}

Fresh properties were measured after the grout had mixed for the designated three minutes. These properties include: bleed water, set time, fresh density, gel time, yield stress, plastic viscosity, flowability, and heat of hydration. The standing (bleed) water was measured on duplicate samples of fresh grout placed in sealed cylinders and left undisturbed for 24 hours. A Vicat needle ${ }^{23}$ was used to determine the final set time of each mix. The fresh density of each mix was determined by pouring the fresh mixture into a density cup with a volume of 8.38 milliliters $(\mathrm{mL})$. The density is determined by dividing the sample mass by the volume of the cup.

Gel Time was determined by two methods: 1) Vane measurement using the Haake rotoviscometer equipped with a four-blade vane which was rotated at one revolution per hour ${ }^{9}$ and 2 ) the pour test. There have been multiple methods for interpreting the stress versus time curve as a result of vane measurements. Previous tests have used the change in slope as the gel time; however, with this method it can be difficult to distinguish between settling and gelling. ${ }^{11}$ Since gelling is a continuous process, the time of the first indication of increased resistance or the change of the slope of the curve will be used as the gel time. ${ }^{11}$ The pour test consists of letting the grout sit undisturbed and pouring a sample every five or ten minutes from a cylinder into an empty container. This pouring is repeated until the fresh grout had developed sufficient structure so it does not flow as a result of its own mass. The time at which the grout does not flow from the cylinder is designated as the gel time.

Rheological flow curves were obtained using a Haake VT550 rotoviscometer equipped with a stationary sample cup and a rotating MVII bob. This instrument has a smooth wall coaxial cylindrical geometry.,11 The flow between the two concentric cylinders is characterized by measuring the torque and speed of the inner cylinder. The torque readings were converted to shear stress and the speed to shear rate. Flow curves (up and down) were generated over a shear rate range of 0 to $300 \mathrm{sec}^{-1}$. Each curve took 150 seconds to accelerate/decelerate. After accelerating to $300 \mathrm{sec}^{-1}$, the shear rate was held for 30 seconds prior to decelerating. Based on the shapes of the down curves, a Bingham Plastic rheological model was used for regression of the data to calculate the plastic viscosity and yield stress of the fresh grout. Equations used to calculate the plastic viscosity and yield stress using the flow curve data are presented elsewhere. ${ }^{9}$ The plastic viscosities and yield stresses were calculated from the data on the decreasing shear rate (down curve) of the flow curves to minimize the impact of any thixotropic behavior of the saltstone on the measurements. 
A modified slump test was used to measure the flowability of the fresh saltstone due to gravity. ${ }^{24}$ Immediately after mixing, the slurry is poured into an open cylinder with one end sitting on a smooth, flat surface. Approximately 30 seconds after the cylinder was filled, it was lifted vertically approximately one inch off the surface to let the grout flow out and spread due to gravity. The diameter of the flowed grout was measured.

The heat of hydration $(\mathrm{HOH})$ for the mixes was determined using an isothermal calorimeter. Mixes with varying extra water amounts and admixture dosages were tested to determine the effect on the heat generated during curing. The isothermal calorimeter was kept at $25{ }^{\circ} \mathrm{C}$ and tests continued for at least three days after mixing.

\subsection{Sample Curing}

Samples were cured under profiles based on temperature data from cell K and cell F in SDU 4. To date, the temperatures in cell $\mathrm{K}$ are the highest recorded in any of the SDUs and the temperature profile of cell $\mathrm{F}$ is typical of temperatures recorded in multiple cells in SDU 4. The data used are actual temperature data recorded by thermocouples in the cells ${ }^{\dagger}$ over several months and approximated to a 28 day cure time. Since the processing conditions cannot be replicated and the cure time for simulated saltstone is significantly decreased compared to actual saltstone in cells $\mathrm{K}$ and F, the cure profiles in Figure 2-1 are only meant to approximate two different processing conditions (pour strategy, etc.) in the SPF. The actual thermocouple data as recorded in the cells $\mathrm{K}$ and $\mathrm{F}$ are provided in Appendix A. A programmable convection oven was used to achieve the curing profiles (Figure 2-1). At the end of the curing profile, the oven temperature was ramped down to room temperature over several days while keeping the humidity high to prevent any drying and cracking of the samples during cooling. Once removed from the oven, samples were kept in a plastic bag with a wet sponge to maintain humid conditions until the cured properties were analyzed.

Modifications to the oven were made to provide a high humidity curing environment while the samples were heated. A control program was used to keep the chamber of the oven at a high relative humidity. Since field conditions vary in the disposal units depending on pour strategy, etc., two curing conditions were investigated. Quadruplicate samples of each formulation were cured in the oven for 28 days. Two of the samples were kept under saturated conditions by adding liquid on top of the grout to maintain complete saturation. The other two samples had the grout surface exposed to the humid environment.

\footnotetext{
${ }^{\dagger}$ Using PI ProcessBook and PI DataLink to analyze the thermocouple readings in SDU 4, cells F and K.
} 


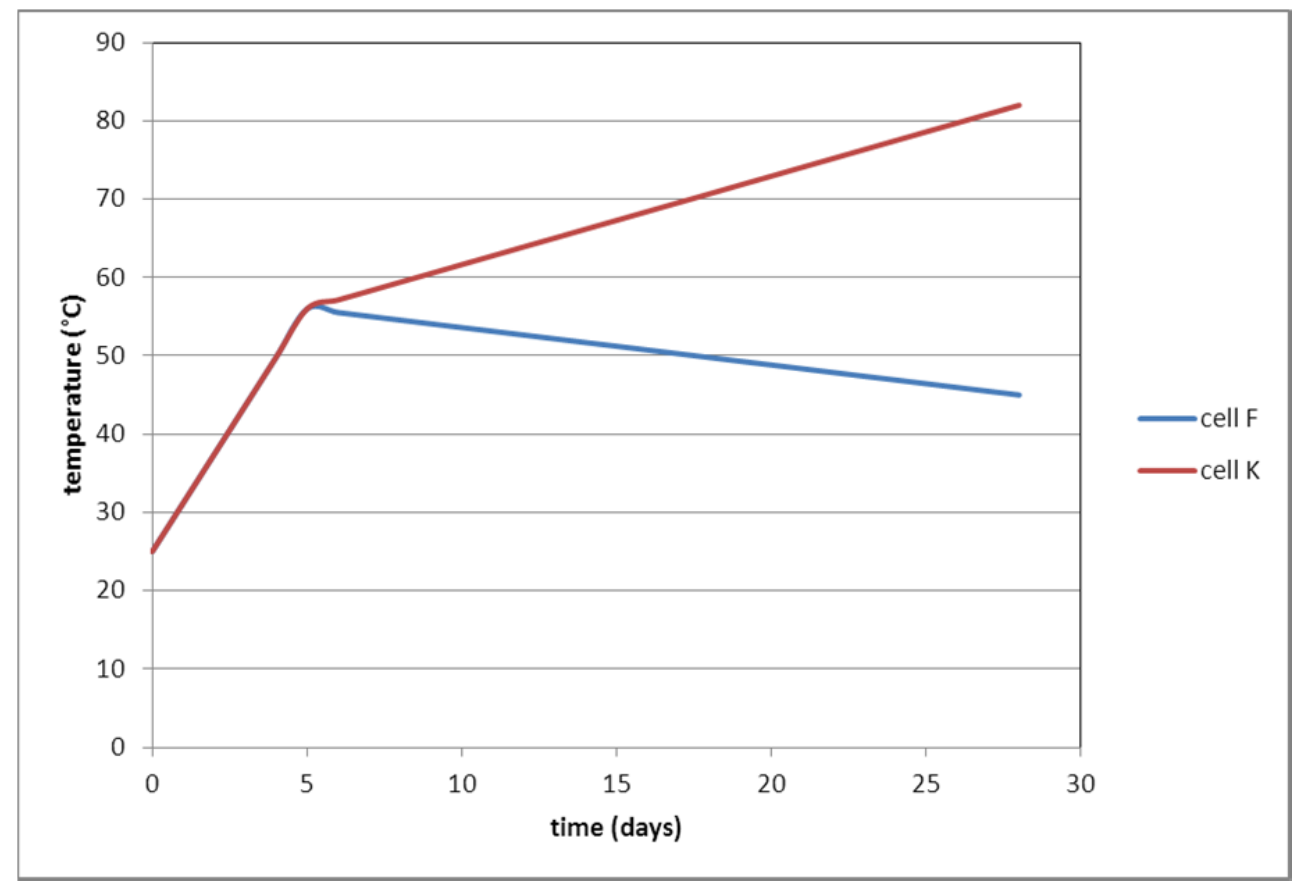

Figure 2-1. Modified cell $F$ and cell $K$ curing profiles

\subsection{Cured Property Measurements}

Cured properties were measured after samples cured for 28 days. Grout is considered "cured" after 28 days since the major hydration reactions are complete within that time. Although hydration reactions continue indefinitely, the ratio of strength gain compared to cure time is minimal after 28 days. The cured properties measured on these samples are hydraulic conductivity, compression strength, porosity, cured density, and leachability index. After the 28 days, the quadruplicate samples were removed from the oven and one sample from each of the curing conditions was used for hydraulic conductivity analysis. The remaining samples were used for the analyzing the other cured properties.

\subsubsection{Hydraulic Conductivity}

The saturated hydraulic conductivity, ${ }^{25}$ dry bulk density, and porosity were measured by an offsite laboratory ${ }^{\ddagger}$ after the samples had cured for 28 days at SRNL. At the offsite laboratory, each 3x6 inch cylindrical sample was cut in half to create duplicate $3 \mathrm{x} 3$ inch samples and labeled as the top and bottom, respectively. The ends of each sample were shaved to ensure parallel surfaces according to the ASTM standard. The saturated hydraulic conductivity of the saltstone samples was determined by ASTM D 5084 method $\mathrm{F}$, the constant-volume falling head using a flexible wall permeameter. ${ }^{25}$ The fluid used for testing was the simple salt solution that did not include reactive species such as aluminum nitrate or phosphates. This was used to avoid interactions of the test fluid and the sample during testing. Saturated hydraulic conductivity (K) is a function of the porous medium and the properties of the test fluid as described by Darcy's law in Equation (2-1). ${ }^{26}$

\footnotetext{
‡ AMEC E\&I (formerly Mactec), 396 Plasters Ave, Atlanta, GA, 30324
} 


$$
\frac{d q}{d t}=K \frac{\Delta H A}{L \mu}
$$

Where $d q / d t$ is the rate of fluid flow, $\mu$ is the viscosity of the fluid, $\Delta H$ is the pressure gradient, $A$ is the surface area, and $L$ is the thickness of the solid. Additional details of the testing and calculations for dry bulk density, porosity and hydraulic conductivity results provided by the offsite laboratory are documented in previous reports. ${ }^{6,27,28}$

\subsubsection{Compressive strength, porosity, cured density}

The bulk density of the cured samples was measured immediately after the samples were removed from the oven. The cured density of each sample was calculated by dividing the sample mass by the volume of the sample. The compression strength of the cured samples was measured using a Humboldt CM-3000LXI compression tester according to ASTM C39 "Compressive strength of Cylindrical Specimens" ${ }^{29}$ According to the procedure, compression testing of moist-cured specimens shall be made as soon as practical after removal from moist storage. ${ }^{29}$ Prior to testing, each sample was removed from the plastic cylinder, weighed and the dimensions were measured. Each sample was centered on the lower block and the load was applied to the sample at a constant rate of $35 \pm 7 \mathrm{psi} / \mathrm{s}$. The compressive load was applied to each sample until the indicator showed a steady decrease in the load and the sample was visibly cracked. ${ }^{29}$ The compressive strength was calculated by dividing the maximum load by the cross-sectional area of the sample.

After completion of compressive strength measurements, two fractured pieces from the center of each sample were used for porosity measurements. The porosity was determined by the mass loss ${ }^{30}$ upon heating samples to $105{ }^{\circ} \mathrm{C}$ in a convection oven. The mass loss was monitored until no further mass loss occurred (approximately 24 hours). The water released during heating $\left(\mathrm{m}_{\mathrm{w}}\right)$ is converted to a volume of simulant $\left(\mathrm{V}_{\text {sim }}\right)$ by dividing by the ratio of the mass of water to the mass of the simulant $(0.710$ for the mid-point ARP/MCU simulant) then dividing again by the density of the simulant $\left(\rho_{\text {sim }}\right)^{30}$ as shown in Equation (2-2). The reported porosity (P) of the cured samples is the simulant volume $\left(\mathrm{V}_{\text {sim }}\left[\mathrm{cm}^{3}\right]\right)$ divided by the sample volume $\left(\mathrm{V}_{\mathrm{s}}\left[\mathrm{cm}^{3}\right]\right)$ as shown in Equation (2-3). ${ }^{30}$

$$
\begin{gathered}
V_{\text {sim }}=\frac{\left(\frac{m_{w}}{0.710}\right)}{\rho_{\text {sim }}} \\
P=\frac{V_{\text {sim }}}{V_{s}}
\end{gathered}
$$

\subsubsection{Leachability Index}

Before the cured saltstone samples could be leach tested using the American National Standard Measurement of the Leachability of Solidified Low-Level Radioactive Wastes by a Short-Term Test Procedure, ${ }^{31}$ they had to be removed from their sample vials (P/N VL25H from Lavials.com). A miter saw was used to cut the bottom edge off the vial, the sample was turned over, and then the sample was pressed out of the vial using a hand press. After the sample was out of the vial, it was cut to approximately $6 \mathrm{~cm}$ using a clean miter saw. The cut dimensions (height and diameter) of the saltstone samples are shown in Table 2-5. The total external surface area (S) of each cut saltstone sample was calculated using Equation (2-4) as follows.

$$
S=\pi * D * H+2 * \pi *\left(\frac{D}{2}\right)^{2}
$$


Where $\mathrm{D}$ is the diameter of the cut sample $[\mathrm{cm}], \mathrm{H}$ is the height of the cut sample $[\mathrm{cm}]$, and $\mathrm{S}$ is the external surface area of the cut sample $\left[\mathrm{cm}^{2}\right]$. The volume of leachant (deionized water) needed for each cut saltstone sample was calculated using Equation (2-5) where $\mathrm{V}_{\mathrm{L}}$ is the volume of leachate $\left[\mathrm{cm}^{3}=\mathrm{mL}\right]$. Note that the deionized water was assumed to have a density of $1 \mathrm{~g} / \mathrm{ml}$ so the volume of leachant calculated in Equation (2-5) was treated as the mass of leachant needed as shown in Table 2-5.

$$
V_{L}=10 * S
$$

The saltstone samples were cut so the volume of leachant to surface area of the saltstone sample was $10 \pm$ $0.2 \mathrm{~cm}$ per ANSI/ANS 16.1-2003. ${ }^{31}$ The samples were cut to approximately $6 \mathrm{~cm}$ long (Table 2-5) rather than using the entire $10 \mathrm{~cm}$ sample in order to reduce the volume of leachate generated with this test. The cut saltstone samples were suspended in the $1 \mathrm{~L}$ bottles with the leachant amounts as shown in Table 2-5. The suspended samples were lowered into each bottle with fresh leachant then lifted out at set times and placed in new bottles with fresh leachant. A blank with just deionized water was created and sampled at each time period to ensure that the leachant was not introducing contaminants into the leachates. ${ }^{31}$ The time periods for the leachate testing were $2,7,24,48,72$, and 96, and 120 hours. ${ }^{31}$ At the end of each elapsed time period, two leachate samples were collected from each bottle. A 125-ml sample was collected for Ion Chromatography (IC) measurements of nitrite $\left(\mathrm{NO}_{2}{ }^{-}\right)$and nitrate $\left(\mathrm{NO}_{3}{ }^{-}\right)$concentrations and Inductively Coupled Plasma Emission Spectroscopy (ICP-ES) measurements of chromium and sodium concentrations. A 30-60 ml sample was collected from each bottle for $\mathrm{pH}$ and conductivity measurements.

Table 2-5. Cut Saltstone sample dimensions and calculations for surface area and leachant volume

\begin{tabular}{|c|c|c|c|c|c|c|c|}
\hline Sample & $\begin{array}{c}\text { Height } \\
\text { (H) } \\
{[\mathrm{cm}]}\end{array}$ & $\begin{array}{l}\text { Diameter } \\
\text { (D) }[\mathrm{cm}]\end{array}$ & $\begin{array}{c}\text { Side } \\
\text { Circumferential } \\
\text { Area }\left[\mathrm{cm}^{2}\right]\end{array}$ & $\begin{array}{c}\text { End } \\
\text { Circular } \\
\text { Area } \\
{\left[\mathrm{cm}^{2}\right]}\end{array}$ & $\begin{array}{c}\text { Total } \\
\text { External } \\
\text { Surface } \\
\text { Area of Cut } \\
\text { Section (S) } \\
{\left[\mathrm{cm}^{2}\right]} \\
\end{array}$ & $\begin{array}{l}\text { Volume of } \\
\text { Cut Section } \\
\text { (V) }\left[\mathrm{cm}^{3}\right]\end{array}$ & $\begin{array}{c}\text { Leachant } \\
\text { Needed } \\
\text { for } \\
V_{L} / S=10 \\
\text { cm }\end{array}$ \\
\hline WP001A & 5.93 & 3.31 & 61.59 & 17.16 & 78.75 & 101.78 & $787.5 \mathrm{~g}$ \\
\hline WP001B & 5.98 & 3.29 & 61.79 & 16.97 & 78.76 & 101.56 & $787.6 \mathrm{~g}$ \\
\hline WP003A & 5.93 & 3.31 & 61.71 & 17.25 & 78.96 & 102.25 & $789.6 \mathrm{~g}$ \\
\hline WP003B & 5.88 & 3.30 & 60.98 & 17.11 & 78.09 & 100.62 & $780.9 \mathrm{~g}$ \\
\hline WP005A & 5.98 & 3.39 & 63.69 & 18.03 & 81.72 & 107.89 & $817.2 \mathrm{~g}$ \\
\hline WP005B & 5.87 & 3.30 & 60.76 & 17.06 & 77.83 & 100.13 & $778.3 \mathrm{~g}$ \\
\hline WP010A & 5.88 & 3.31 & 61.21 & 17.23 & 78.44 & 101.37 & $784.4 \mathrm{~g}$ \\
\hline WP010B & 5.84 & 3.30 & 60.52 & 17.11 & 77.63 & 99.86 & $776.3 \mathrm{~g}$ \\
\hline WP011A & 5.84 & 3.30 & 60.47 & 17.05 & 77.53 & 99.63 & $775.3 \mathrm{~g}$ \\
\hline WP011B & 5.86 & 3.29 & 60.66 & 17.03 & 77.70 & 99.88 & $777.0 \mathrm{~g}$ \\
\hline WP014A & 5.89 & 3.28 & 60.67 & 16.91 & 77.58 & 99.53 & $775.8 \mathrm{~g}$ \\
\hline WP014B & 5.87 & 3.29 & 60.61 & 16.99 & 77.60 & 99.68 & $776.0 \mathrm{~g}$ \\
\hline WP018A & 5.88 & 3.29 & 60.81 & 17.00 & 77.81 & 100.03 & $778.1 \mathrm{~g}$ \\
\hline WP018B & 5.79 & 3.29 & 59.81 & 16.98 & 76.79 & 98.32 & $767.9 \mathrm{~g}$ \\
\hline WP021A & 5.97 & 3.32 & 62.15 & 17.26 & 79.41 & 103.02 & $794.1 \mathrm{~g}$ \\
\hline WP021B & 5.98 & 3.30 & 61.92 & 17.06 & 78.99 & 102.05 & $789.9 \mathrm{~g}$ \\
\hline WP023A & 5.79 & 3.28 & 59.69 & 16.91 & 76.60 & 97.92 & $766.0 \mathrm{~g}$ \\
\hline WP023B & 5.82 & 3.32 & 60.80 & 17.35 & 78.14 & 101.02 & $781.4 \mathrm{~g}$ \\
\hline
\end{tabular}




\subsection{Results and Discussion}

\subsection{Fresh Properties}

The fresh properties of the grout mixes are important to ensure the product can be processed through the facility and transferred to the SDF SDU. In the SDU, the grout should be formulated such that it sets within three days and produces less than three volume percent of bleed water. The gel time of the fresh grout should be between 20 and 60 minutes. ${ }^{11,32}$ A gel time of less than 20 minutes limits the workability of the grout during a process upset while it is in the facility and a gel time of longer than 60 minutes can lead to settling and segregation of the grout. The specified gel range is to ensure processability through the facility and to ensure that sufficient microstructure develops once the grout is placed in the SDU. Development of the structure over a short time period helps prevent segregation of the grout components (liquid from solids). Bleed water on top of the set grout is an indication that segregation is occurring. ${ }^{26}$

\subsubsection{Fresh Density, Heat of Hydration, Flowability, Bleed and Set Time}

The fresh density, flowability, set time, bleed, and heat of hydration data for all mixes are listed in Table 3-1.

Table 3-1. Fresh density, flowability, set, bleed, and heat of hydration for all mixes

\begin{tabular}{|c|c|c|c|c|c|c|c|c|}
\hline \multirow{2}{*}{ Sample } & \multicolumn{2}{|c|}{ w/p ratio } & \multirow{2}{*}{$\begin{array}{c}\text { Fresh Density } \\
(\mathrm{g} / \mathrm{mL})\end{array}$} & \multirow{2}{*}{$\begin{array}{c}\text { Flowability } \\
\text { (cm) }\end{array}$} & \multirow{2}{*}{$\begin{array}{c}\text { Set Time } \\
\text { (days) }\end{array}$} & \multicolumn{2}{|c|}{ Bleed (vol \%) } & \multirow{2}{*}{$\begin{array}{c}\text { HOH } \\
(\mathrm{J} / \mathrm{g}) \\
\end{array}$} \\
\hline & Start & Finish & & & & Day 1 & Day 3 & \\
\hline WP001 & 0.59 & 0.59 & 1.728 & 23.02 & 1 & \multicolumn{2}{|c|}{ wet surface } & 162.19 \\
\hline WP002 & 0.56 & 0.56 & 1.730 & 21.75 & 1 & \multicolumn{2}{|c|}{ dry surface } & 175.64 \\
\hline WP003 & 0.67 & 0.67 & 1.678 & 22.38 & 3 & 0.41 & 0.00 & 149.09 \\
\hline WP004 & 0.59 & $0.59^{\mathrm{a}}$ & 1.730 & 21.35 & 1 & 1.49 & 0.00 & 153.84 \\
\hline WP005 & 0.56 & $0.7^{\mathrm{a}, \mathrm{b}}$ & 1.651 & 25.00 & 2 & 0.73 & 0.00 & 142.65 \\
\hline WP006 & 0.52 & 0.52 & 1.802 & 18.73 & 1 & 1.14 & 0.00 & 151.24 \\
\hline WP007 & 0.53 & $0.53^{\mathrm{a}}$ & 1.784 & 20.56 & 2 & 1.42 & 0.00 & 162.36 \\
\hline WP008 & 0.55 & $0.62^{\mathrm{C}}$ & 1.698 & 22.07 & 3 & 1.21 & 0.00 & 165.58 \\
\hline WP009 & 0.69 & $0.69^{\mathrm{a}}$ & 1.680 & 25.72 & 3 & 2.91 & 1.57 & 141.36 \\
\hline WP010 & 0.58 & $0.72^{\mathrm{a}, \mathrm{b}}$ & 1.639 & 27.31 & 2 & 1.19 & 0.00 & 148.58 \\
\hline WP011 & 0.57 & $0.64^{\mathrm{C}}$ & 1.684 & 24.37 & 3 & 1.66 & 0.79 & 134.56 \\
\hline WP012 & 0.54 & $0.54^{\mathrm{a}}$ & 1.751 & 21.59 & 2 & \multicolumn{2}{|c|}{ wet surface } & 136.67 \\
\hline WP013 & 0.54 & $0.68^{\mathrm{b}}$ & 1.658 & 24.92 & 2 & 1.72 & 0.78 & 145.14 \\
\hline WP014 & 0.55 & 0.55 & 1.742 & 21.43 & 1 & 0.33 & 0.00 & 172.32 \\
\hline WP015 & 0.61 & 0.61 & 1.701 & 24.69 & 1 & 1.02 & 0.00 & $\mathrm{n} / \mathrm{a}$ \\
\hline WP016 & 0.58 & $0.58^{\mathrm{a}}$ & 1.723 & 22.38 & 1 & \multicolumn{2}{|c|}{ wet surface } & 140.98 \\
\hline WP017 & 0.57 & $0.57^{\mathrm{a}}$ & 1.730 & 22.23 & 2 & \multicolumn{2}{|c|}{ dry surface } & 159.00 \\
\hline WP018 & 0.73 & 0.73 & 1.653 & 28.10 & 4 & 1.99 & 1.84 & 151.28 \\
\hline WP019 & 0.71 & $0.71^{\mathrm{a}}$ & 1.693 & 28.26 & 2 & 1.16 & 0.00 & 161.27 \\
\hline WP020 & 0.63 & 0.63 & 1.710 & 24.45 & 2 & 0.80 & 0.00 & 160.72 \\
\hline WP021 & 0.53 & $0.6^{\mathrm{a}, \mathrm{c}}$ & 1.707 & 21.35 & 2 & 0.28 & 0.00 & 133.89 \\
\hline WP022 & 0.65 & $0.65^{\mathrm{a}}$ & 1.691 & 25.80 & 2 & 0.22 & 0.00 & 158.00 \\
\hline WP023 & 0.51 & 0.51 & 1.794 & 18.57 & 1 & \multicolumn{2}{|c|}{ dry surface } & 132.92 \\
\hline WP024 & 0.59 & $0.66^{\mathrm{a}, \mathrm{c}}$ & 1.668 & 26.51 & 3 & 1.04 & 0.00 & 157.07 \\
\hline WP025 & 0.59 & $0.74^{\mathrm{b}}$ & 1.637 & 26.59 & 3 & 1.77 & 1.46 & 169.85 \\
\hline
\end{tabular}

${ }^{\mathrm{a}}$ Samples with admix included in the formulation

${ }^{\mathrm{b}}$ Formulation with $8 \mathrm{wt} \%$ extra water

${ }^{\mathrm{c}}$ Formulation with 4 wt \% extra water 
As shown in Table 3-1, all mixes were set within three days except for mix WP018 which set in four days. This is expected since this mix has a w/p of 0.73 , which is the highest of all the mixes tested using only salt solution. In general, the mixes with Daratard had longer set times. This is expected since this admixture is designed to be a set retarder. The extra water did have an effect on the set time of the samples and made the material flow out from the cylinder in a larger diameter. The set time of samples with extra water was extended since fly ash and slag are activated by alkali solutions and have very slow reactions with water. ${ }^{33-37}$ Therefore, diluting the salt solution with water will delay the hydration reactions of the slag and fly ash, leading to longer set times. The delayed reaction is indicated by the lower $\mathrm{HOH}$ values for mixes with extra water or admix compared to mixes without any additions.

Mixes that are more fluid are also less dense and generally had a higher volume percentage of bleed than the mixes that were denser. The data show that admixtures had no effect on the bleed water of a mix except for mix WP009, which had the most bleed after one day of all the samples. Mixes with starting w/p ratios of 0.59 or lower with no extra water or admixes had little (wet surface, no measurable bleed) or no bleed water (dry surface). Samples that were formulated low starting w/p ratios (below 0.59) plus 4\% extra water did generate bleed after one day; however, all the bleed was reabsorbed after three days. The samples that were formulated with high starting w/p ratios or $8 \%$ extra bleed water had excess (standing) bleed water after three days.

In summary, the $8 \mathrm{wt} \%$ extra water in the formulation causes the saltstone to generate more bleed water as it cures than the samples with $4 \mathrm{wt} \%$ extra water or salt solution only. Limiting the amount of extra water in the SPF would limit the amount of settling and excess bleed water of the saltstone in the SDUs. Adding Daratard to w/p ratios greater than 0.66 causes longer set times and in some cases, standing bleed water after three days; therefore its use should be limited or avoided. Adding extra water to the formulations with w/p ratios of 0.58 or lower does not increase the set time past three days and the bleed water is reabsorbed after three days (with the exception of WP011). Therefore, only considering the properties of bleed water and set time, it is feasible to process w/p ratios below 0.58 by adding extra water or admix.

\subsubsection{Gel Time}

As shown in Table 3-2 as well as the figures in Appendix B, extra water or admixtures in the saltstone formulation delays the gel time of the sample. Gel times from $20-60$ minutes are acceptable as long as there is no settling occurring. ${ }^{11,32}$ Long gel times are beneficial for the SPF to ensure processability through the facility; however, longer gel times often lead to settling and higher bleed water generation in the SDF SDUs. The vane rheology method for determining the gel time of a sample provides insight into the structure development of the sample; however, it is difficult to distinguish the gel time from settling or other reactions based on the results obtained thus far. If this method is further developed, it could be less subjective than the pour test and provide more understanding into the hydration and structure development of fresh saltstone.

Based on the results presented in Table 3-2, saltstone formulations with low w/p ratios (0.56 or lower) without any admixture or extra water, gel too quickly $(<20 \mathrm{~min})$ to ensure reliable processing through the facility; however, if admix is used in these formulations, the gel time is extended into the acceptable range of $20-60$ minutes. However, adding $8 \mathrm{wt} \%$ extra water to the low w/p formulations increases the gel time past 60 minutes. Therefore, for gel time it may be feasible to use Daratard to process low w/p ratios as long as the dosage is very well controlled and can remain at $0.05 \mathrm{wt} \%$; however, using $8 \mathrm{wt} \%$ extra water extends the gel time past the acceptable limits for these formulations. 
Table 3-2. Comparison of gel time measurements for all mixes

\begin{tabular}{||c|c|c|c|c|c||}
\hline \multirow{2}{*}{ Sample } & Starting & Extra Water & \multirow{2}{*}{$\begin{array}{c}\text { Final } \\
\text { w/p ratio }\end{array}$} & (w) & \multicolumn{2}{|c|}{ Gel Time (min) } \\
\cline { 5 - 6 } & w/p ratio & Pour & Vane \\
\hline \hline WP001 & 0.59 & 0 & 0.59 & 30 & 35 \\
\hline WP002 & 0.56 & 0 & 0.56 & 15 & 18 \\
\hline WP003 & 0.67 & 0 & 0.67 & 40 & 55 \\
\hline WP004 & 0.59 & 0 & $0.59^{\mathrm{a}}$ & 40 & 55 \\
\hline WP005 & 0.56 & 8 & $0.7^{\mathrm{a}}$ & 35 & $60+$ \\
\hline WP006 & 0.52 & 0 & 0.52 & 20 & 13 \\
\hline WP007 & 0.53 & 0 & $0.53^{\mathrm{a}}$ & 40 & 21 \\
\hline WP008 & 0.55 & 4 & 0.62 & 50 & 34 \\
\hline WP009 & 0.69 & 0 & $0.69^{\mathrm{a}}$ & 120 & $60+$ \\
\hline WP010 & 0.58 & 8 & $0.72^{\mathrm{a}}$ & 45 & 55 \\
\hline WP011 & 0.57 & 4 & 0.64 & 60 & 44 \\
\hline WP012 & 0.54 & 0 & $0.54^{\mathrm{a}}$ & 50 & 43 \\
\hline WP013 & 0.54 & 8 & 0.68 & 60 & $60+$ \\
\hline WP014 & 0.55 & 0 & 0.55 & 20 & 14 \\
\hline WP015 & 0.61 & 0 & 0.61 & 50 & 37 \\
\hline WP016 & 0.58 & 0 & $0.58^{\mathrm{a}}$ & 20 & 37 \\
\hline WP017 & 0.57 & 0 & $0.57^{\mathrm{a}}$ & 13 & 30 \\
\hline WP018 & 0.73 & 0 & 0.73 & 70 & $60+$ \\
\hline WP019 & 0.71 & 0 & $0.71^{\mathrm{a}}$ & 43 & $60+$ \\
\hline WP020 & 0.63 & 0 & 0.63 & 32 & 33 \\
\hline WP021 & 0.53 & 4 & $0.60^{\mathrm{a}}$ & 20 & 40 \\
\hline WP022 & 0.65 & 0 & $0.65^{\mathrm{a}}$ & 36 & 45 \\
\hline WP023 & 0.51 & 0 & 0.51 & 15 & 13 \\
\hline WP024 & 0.59 & 4 & $0.66^{\mathrm{a}}$ & 17 & 42 \\
\hline WP025 & 0.59 & 8 & 0.74 & 20 & 58 \\
\hline \hline
\end{tabular}

${ }^{\text {a }}$ Samples with admix included in the formulation

\subsubsection{Rheology Flow Curve}

The yield stress and plastic viscosity results, calculated using a Bingham plastic model, are listed in Table 3-3 in order of lowest to highest yield stress. Saltstone slurries with higher flowability (Table 3-1) also have lower yield stress and plastic viscosities. The yield stress and plastic viscosity of a mixture is dependent on the final w/p ratio of the formulation. As shown in Figure 3-1, adding Daratard or extra water or both to the initial saltstone formulation lowers the yield stress and plastic viscosity of that mixture. The rheological properties can also be changed by increasing or decreasing the w/p ratio of the saltstone formulation without adding any admixtures or extra water (Figure 3-2).

All of the mixes analyzed in this study have rheological properties that meet acceptance criteria $(<8.5 \mathrm{~Pa})$ except for mix WP023. ${ }^{11,32}$ Another part of the acceptance criteria for yield stress is "as low as possible without bleed." ${ }^{\prime 1,32}$ As shown in Table 3-3, mixes with high final w/p ratios (greater than 0.66) have low yield stresses and plastic viscosities which meets the criteria for processing through the SPF and increased flowability in the SDU; however, these mixes also have high bleed water and long gel and set times. 
Table 3-3. Yield stress and plastic viscosity results for all mixes from lowest to highest

\begin{tabular}{|c|c|c|c|c|c|}
\hline Sample & $\begin{array}{c}\text { w/p } \\
\text { start } \\
\end{array}$ & $\begin{array}{c}\text { flush water } \\
\text { (wt\%) }\end{array}$ & $\begin{array}{c}\text { w/p } \\
\text { final } \\
\end{array}$ & $\begin{array}{c}\text { Yield Stress } \\
\text { (Pa) } \\
\end{array}$ & $\begin{array}{c}\text { Plastic Viscosity } \\
\text { (cP) }\end{array}$ \\
\hline WP019 & 0.71 & 0 & $0.71^{\mathrm{a}}$ & 2.03 & 44.12 \\
\hline WP009 & 0.69 & 0 & $0.69^{\mathrm{a}}$ & 2.06 & 49.83 \\
\hline WP018 & 0.73 & 0 & 0.73 & 2.11 & 42.90 \\
\hline WP013 & 0.54 & 8 & 0.68 & 3.09 & 48.12 \\
\hline WP015 & 0.61 & 0 & 0.61 & 3.18 & 58.50 \\
\hline WP010 & 0.58 & 8 & $0.72^{\mathrm{a}}$ & 3.20 & 41.56 \\
\hline WP005 & 0.56 & 8 & $0.70^{\mathrm{a}}$ & 3.25 & 43.65 \\
\hline WP003 & 0.67 & 0 & 0.67 & 3.32 & 49.43 \\
\hline WP022 & 0.65 & 0 & $0.65^{\mathrm{a}}$ & 3.36 & 53.81 \\
\hline WP025 & 0.59 & 8 & 0.74 & 3.59 & 40.59 \\
\hline WP024 & 0.59 & 4 & $0.66^{\mathrm{a}}$ & 3.64 & 52.24 \\
\hline WP004 & 0.59 & 0 & $0.59^{\mathrm{a}}$ & 3.89 & 80.79 \\
\hline WP020 & 0.63 & 0 & 0.63 & 3.97 & 67.10 \\
\hline WP008 & 0.55 & 4 & 0.62 & 4.07 & 64.88 \\
\hline WP012 & 0.54 & 0 & $0.54^{\mathrm{a}}$ & 5.04 & 121.81 \\
\hline WP011 & 0.57 & 4 & 0.64 & 5.08 & 62.21 \\
\hline WP007 & 0.53 & 0 & $0.53^{\mathrm{a}}$ & 5.19 & 116.15 \\
\hline WP016 & 0.58 & 0 & $0.58^{\mathrm{a}}$ & 5.29 & 84.20 \\
\hline WP021 & 0.53 & 4 & $0.60^{\mathrm{a}}$ & 5.43 & 70.40 \\
\hline WP001 & 0.59 & 0 & 0.59 & 5.51 & 76.07 \\
\hline WP017 & 0.57 & 0 & $0.57^{\mathrm{a}}$ & 5.72 & 109.08 \\
\hline WP002 & 0.56 & 0 & 0.56 & 6.66 & 95.02 \\
\hline WP014 & 0.55 & 0 & 0.55 & 7.37 & 101.63 \\
\hline WP006 & 0.52 & 0 & 0.52 & 7.58 & 135.32 \\
\hline WP023 & 0.51 & 0 & 0.51 & 10.03 & 138.19 \\
\hline
\end{tabular}

${ }^{\mathrm{a}}$ Samples with admix included in the formulation 
SRNL-STI-2012-00558

Revision 0

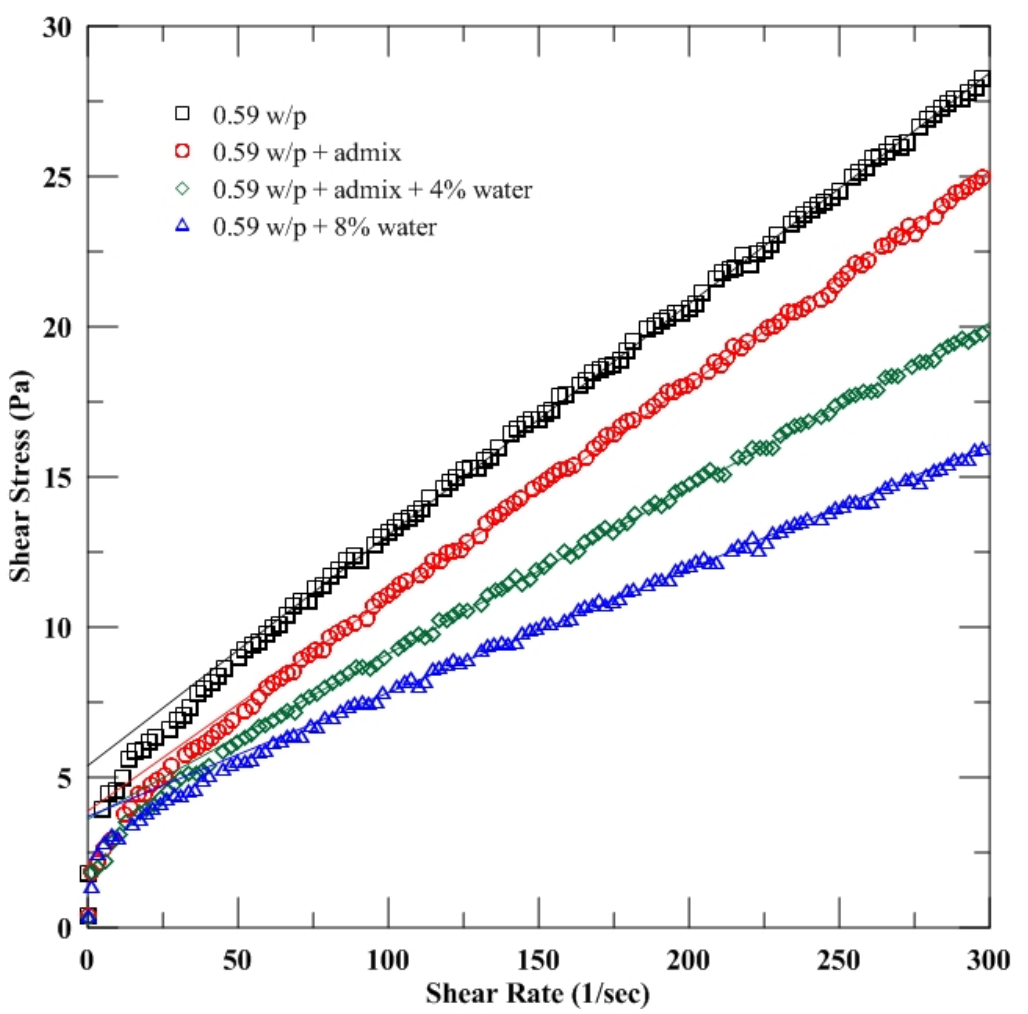

Figure 3-1. Flow curves (decreasing shear rate) for samples starting at $0.59 \mathrm{w} / \mathrm{p}$ and adding admixture or extra water or both

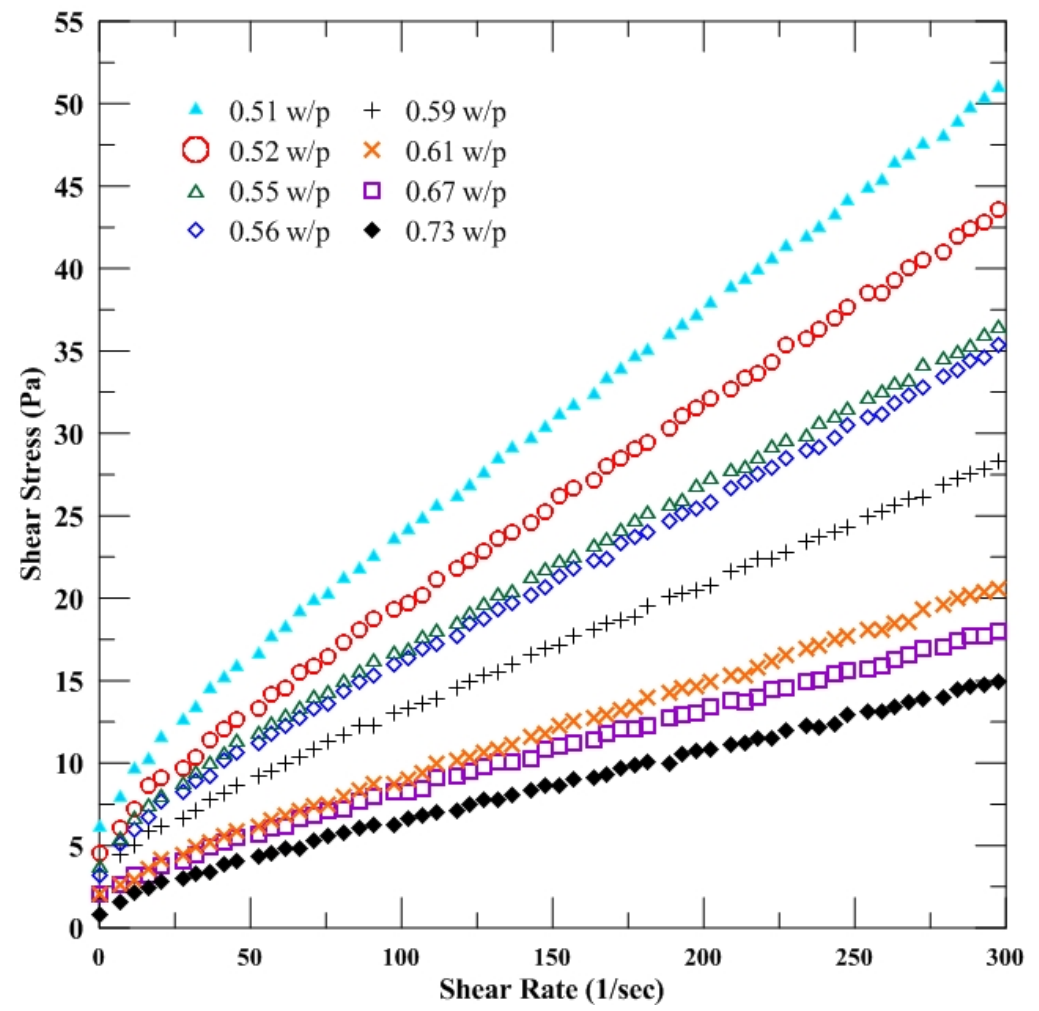

Figure 3-2. Flow curves (decreasing shear rate) for all mixes made without admix or extra water 


\subsection{Cured Properties}

The impact of curing temperature on the performance (cured) properties of saltstone has been studied extensively. ${ }^{5-8,38}$ All of the samples analyzed in these previous studies were cured in an environment with uncontrolled humidity, resulting in drying out of the saltstone. These studies showed that the performance properties of saltstone decreased with increasing curing temperatures; however it was unclear whether the deleterious effects of curing at high temperatures were solely due to drying out of the grout or whether there were other effects of curing at high temperatures that caused the poor performance properties. ${ }^{8}$ The results presented in this report investigate the impact of curing environment (saturated conditions and exposure to high humidity) and temperature on the cured properties of saltstone formulated with various amounts of extra water as well as with and without admixtures. It should be noted that the samples in the previous study were cured for a total of 90 days prior to analysis whereas the samples in this study cured for 28 days. It is accepted in the grout industry that the majority of the hydration reactions have occurred after 28 days and although curing continues, the performance properties do not change significantly between 28 and 90 days of curing. ${ }^{26,39}$

\subsubsection{Porosity and Bulk Density}

Grout porosity is generally defined as the percentage of total volume of cured grout that is not occupied by either the starting cementitious materials (in this case, portland cement, blast furnace slag, and Class F fly ash) or the products that results from reaction of these cementitious materials with water (calcium silicate hydrate, calcium hydroxide crystals, etc.). ${ }^{26}$ For saltstone mixes, the pore volume is occupied by a salt solution. ${ }^{7,8}$ The cured bulk density is calculated from the cured weight and dimensions of each sample after curing for 28 days. The porosity and bulk density are reported in Table 3-4 in order of samples formulated with the lowest to highest final w/p ratio. These results support the conclusions from previous studies and literature that the porosity and bulk density of saltstone have an inverse relationship primarily controlled by the w/p ratio. ${ }^{6,8}$ Samples formulated at low w/p ratios are denser and have lower porosity than samples at higher w/p ratios (Table 3-4) and have higher compressive strength and lower hydraulic conductivity as discussed in the following sections.

Table 3-4. Bulk density and porosity of samples, listed from lowest to highest final w/p ratio, cured under cell $\mathrm{K}$ and cell $\mathrm{F}$ temperature profiles

\begin{tabular}{|c|c|c|c|c|c|c|c|c|c|c|}
\hline \multirow{3}{*}{ Sample } & \multirow{3}{*}{$\begin{array}{l}\text { Start } \\
\mathbf{w} / \mathbf{p} \\
\text { ratio }\end{array}$} & \multirow{3}{*}{$\begin{array}{l}\text { Final } \\
\text { w/p } \\
\text { ratio }\end{array}$} & \multicolumn{4}{|c|}{ Cell K } & \multicolumn{4}{|c|}{ Cell F } \\
\hline & & & \multicolumn{2}{|c|}{ Saturated } & \multicolumn{2}{|c|}{ Exposed Surface } & \multicolumn{2}{|c|}{ Saturated } & \multicolumn{2}{|c|}{ Exposed Surface } \\
\hline & & & $\begin{array}{l}\text { Density } \\
\left(\mathrm{g} / \mathrm{cm}^{3}\right)\end{array}$ & $\begin{array}{c}\mathbf{P} \\
(\%)\end{array}$ & $\begin{array}{l}\text { Density } \\
\left(\mathrm{g} / \mathrm{cm}^{3}\right)\end{array}$ & $\begin{array}{c}\mathbf{P} \\
(\%)\end{array}$ & $\begin{array}{l}\text { Density } \\
\left(\mathrm{g} / \mathrm{cm}^{3}\right)\end{array}$ & $\begin{array}{c}\mathbf{P} \\
(\%)\end{array}$ & $\begin{array}{l}\text { Density } \\
\left(\mathrm{g} / \mathrm{cm}^{3}\right)\end{array}$ & $\begin{array}{c}P \\
(\%)\end{array}$ \\
\hline WP023 & 0.51 & 0.51 & 1.787 & 63.5 & 1.796 & 57.5 & 1.793 & 55.1 & 1.789 & 55.3 \\
\hline WP014 & 0.55 & 0.55 & 1.792 & 60.9 & 1.771 & 61.2 & 1.789 & 58.4 & 1.767 & 57.1 \\
\hline WP001 & 0.59 & 0.59 & 1.755 & 64.1 & 1.736 & 61.3 & 1.759 & 69.9 & 1.752 & 59.9 \\
\hline WP021 & 0.53 & $0.60^{\mathrm{a}, \mathrm{c}}$ & 1.741 & 64.9 & 1.719 & 62.3 & 1.732 & 60.5 & 1.733 & 61.3 \\
\hline WP011 & 0.57 & $0.64^{\mathrm{c}}$ & 1.700 & 65.3 & 1.686 & 60.3 & 1.722 & 61.3 & 1.700 & 62.5 \\
\hline WP003 & 0.67 & 0.67 & 1.715 & 67.3 & 1.692 & 62.5 & 1.705 & 62.1 & 1.715 & 63.2 \\
\hline WP005 & 0.56 & $0.70^{\mathrm{a}, \mathrm{b}}$ & 1.669 & 69.6 & 1.660 & 64.3 & 1.659 & 64.1 & 1.685 & 65.8 \\
\hline WP010 & 0.58 & $0.72^{\mathrm{a}, \mathrm{b}}$ & 1.677 & 69.1 & 1.671 & 64.7 & 1.673 & 68.1 & 1.642 & 66.6 \\
\hline WP018 & 0.73 & 0.73 & 1.691 & 66.2 & 1.677 & 64.8 & 1.703 & 66.6 & 1.679 & 66.8 \\
\hline
\end{tabular}

${ }^{\mathrm{a}}$ Samples with admix included in the formulation

${ }^{\mathrm{b}}$ Formulation with $8 \mathrm{wt} \%$ extra water

${ }^{\mathrm{c}}$ Formulation with $4 \mathrm{wt} \%$ extra water

In a previous study, it was reported that curing temperature has an effect on the porosity and density of saltstone; however, the mass loss of the sample as a result of curing at elevated temperatures would affect 
the cured density and therefore the grout porosity, since the cured density is used to calculate the grout porosity. $^{8}$ Therefore, since these prior study samples were cured in an environment with uncontrolled humidity, the cured properties, specifically density, were more affected by drying than cure temperature alone. In fact, the rapid hydration at higher temperatures leads to encapsulation of porous cementitious materials by a layer of dense hydrated product, causing an overall decrease in grout porosity, assuming that the cementitious materials are completely hydrated. ${ }^{26,39}$ Therefore, since the samples in this study were cured in a high humidity environment and not dehydrated, the densities of these samples are higher than those cured in an uncontrolled environment. For example, samples in the previous study formulated at $0.55 \mathrm{w} / \mathrm{p}$ with no admixtures and cured at $60^{\circ} \mathrm{C}$ had densities of 1.711 and $1.769 \mathrm{~g} / \mathrm{mL}$ for the low and high aluminate solutions, respectively. ${ }^{8}$ In this study, the same formulation was cured to 55 and $80{ }^{\circ} \mathrm{C}$ under saturated conditions resulting in densities of 1.789 and $1.792 \mathrm{~g} / \mathrm{cm}^{3}$, respectively (Table 3-4).

\subsubsection{Compressive Strength}

Although the compressive strength of saltstone is not an input in to the PA, it is a property that provides insight into other properties of the material, such as hydraulic conductivity, porosity and density. Higher density grouts will have higher compressive strength and lower hydraulic conductivity. This is due to lower void spaces and lower porosity in the grout resulting in a higher strength material. ${ }^{39}$ There are other factors that determine the compressive strength of a grout that include the microstructure, w/p ratio (including admixtures), the mixing conditions, the curing conditions (especially temperature and $\mathrm{RH}$ ), the age, and the matter of testing (including water content in the sample. ${ }^{39}$ Table 3-5 lists the compressive strength of all the samples in order of lowest to highest final w/p ratio. The general trend of the data is that low w/p samples have higher compressive strengths.

A previous report on the compressive strength of saltstone has shown a decrease in strength as a result of higher curing temperatures (approximately 1240 psi at $20^{\circ} \mathrm{C}$ to $1090 \mathrm{psi}$ at $40{ }^{\circ} \mathrm{C}$ ); ${ }^{7}$ however, these samples may have been dried out, which would lead to the lower compressive strength. As shown in Table 3-5, the compressive strength of samples cured under high $\mathrm{RH}$ and temperature profiles up to 80 and $55{ }^{\circ} \mathrm{C}$ are greater than or equal to the 1240 psi recorded from room temperature cured samples, ${ }^{7}$ indicating that higher cure temperatures benefit the saltstone cured properties, provided the material is not dried out. The data in Table 3-5 shows that curing in a high humidity environment is important, than if the sample is saturated or has the surface exposed to the environment. The cell $\mathrm{K}$ samples have a higher average compressive strength than the cell $\mathrm{F}$ samples but the standard deviation indicates the two cure profiles result in saltstone with comparable compressive strengths. 
Table 3-5. Compressive strength of samples, listed from lowest to highest final w/p ratio, cured under cell $\mathrm{K}$ and cell $\mathrm{F}$ temperature profiles

\begin{tabular}{|c|c|c|c|c|c|c|}
\hline \multirow{3}{*}{ Sample } & \multirow{3}{*}{$\begin{array}{l}\text { Starting } \\
\text { w/p ratio }\end{array}$} & \multirow{3}{*}{$\begin{array}{c}\text { Final } \\
\text { w/p ratio }\end{array}$} & \multicolumn{4}{|c|}{ Compressive strength (psi) } \\
\hline & & & \multicolumn{2}{|r|}{ Cell K } & \multicolumn{2}{|c|}{ Cell F } \\
\hline & & & Saturated & Exposed Surface & Saturated & Exposed Surface \\
\hline WP023 & 0.51 & 0.51 & 3039 & 2978 & 2696 & 2645 \\
\hline WP014 & 0.55 & 0.55 & 2994 & 3238 & 2372 & 2447 \\
\hline WP001 & 0.59 & 0.59 & 3072 & 3033 & 1636 & 2193 \\
\hline WP021 & 0.53 & $0.60^{\mathrm{a}, \mathrm{c}}$ & 1743 & 1837 & 1837 & 1754 \\
\hline WP011 & 0.57 & $0.64^{\mathrm{C}}$ & 1988 & 1737 & 1994 & 2016 \\
\hline WP003 & 0.67 & 0.67 & 1635 & 2307 & 1491 & 1380 \\
\hline WP005 & 0.56 & $0.70^{\mathrm{a}, \mathrm{b}}$ & 1418 & 1441 & 1229 & 1266 \\
\hline WP010 & 0.58 & $0.72^{\mathrm{a}, \mathrm{b}}$ & 1168 & 1399 & 1264 & 1277 \\
\hline WP018 & 0.73 & 0.73 & 1368 & 1475 & 1005 & 1036 \\
\hline \multicolumn{3}{|c|}{ Average } & 2047 & 2161 & 1725 & 1779 \\
\hline \multicolumn{3}{|c|}{ Standard Deviation } & 777 & 747 & 557 & 576 \\
\hline
\end{tabular}

${ }^{\text {a }}$ Samples with admix included in the formulation

${ }^{\mathrm{b}}$ Formulation with 8 wt \% extra water

${ }^{\mathrm{c}}$ Formulation with $4 \mathrm{wt} \%$ extra water

\subsubsection{Hydraulic Conductivity}

Permeability is defined as the property that governs the rate of flow of a fluid into a porous solid. For steady-state flow, the coefficient of permeability, also known as hydraulic conductivity, is determined by Darcy's Equation (2-1). ${ }^{26}$ The saturated hydraulic conductivity (Table 3-6) was measured on the top and bottom of each sample after curing for 28 days under each temperature profile. The samples were split to provide duplicate measurements on a single sample. All of the samples had a hydraulic conductivity of 4.5E-8 to $4.3 \mathrm{E}-10 \mathrm{~cm} / \mathrm{s}$. Of the 72 samples analyzed, only three samples had hydraulic conductivities on the order of $1 \mathrm{E}-7 \mathrm{~cm} / \mathrm{s}$ (the saturated WP010 sample and both WP003 samples, all cured under the cell K profile). On average, the cell $\mathrm{K}$ samples had slightly higher hydraulic conductivities for samples at higher $\mathrm{w} / \mathrm{p}$ ratios than the cell $\mathrm{F}$ samples; however, the majority of the samples have hydraulic conductivities within the range of E-9 or E- $10 \mathrm{~cm} / \mathrm{s}$.

As shown in literature, there is an exponential relationship between porosity and the hydraulic conductivity or strength of grout. As the porosity increases, the strength decreases and hydraulic conductivity increases. ${ }^{26,39}$ Comparing the results in Table 3-4 and Table 3-5, there is a general trend that the samples with the highest porosity (higher w/p ratios) have the lowest strength and therefore highest hydraulic conductivity which indicates the w/p ratio of the formulation effects the cured properties of saltstone. However, for the hydraulic conductivity results reported in Table 3-6, it is difficult to find a trend in the data based on w/p ratio.

The results from a previous study showed a slight trend of increasing hydraulic conductivity with increasing $\mathrm{w} / \mathrm{p}$ ratio, but the primary trend was higher temperatures resulted in higher hydraulic conductivities. ${ }^{8}$ In that study, a range of sample formulations were cured isothermally at 20,40 and $60{ }^{\circ} \mathrm{C}$ for 28 days followed by a 62 day cure at room temperature. These samples had hydraulic conductivities ranging from $1.04 \mathrm{E}-9$ to $1.90 \mathrm{E}-6 \mathrm{~cm} / \mathrm{s}$, with the majority of the $60{ }^{\circ} \mathrm{C}$ samples having hydraulic conductivities greater than 1.0E-7. ${ }^{8}$ It was determined that those samples were dried out, causing microcracks in the sample and higher hydraulic conductivities. ${ }^{8,39}$ Comparing the results presented in Table 3-6 to the results from a previous study, the curing conditions have a greater effect on the hydraulic conductivity of saltstone than the w/p ratio. The saltstone in the current study was cured in a high 
humidity environment which allowed the microstructure to develop without being dehydrated, reducing the formation of microcracks.

Another previous study showed the impact of initial cure temperature on cured saltstone properties. This study showed that saltstone cured at room temperature followed by a high temperature cure had better performance properties than the same saltstone formulation cured at high temperature followed by curing at room temperature. ${ }^{7}$ Therefore, the combination of curing saltstone in a saturated or high humidity environment and under a ramped temperature profile results in slower hydraulic conductivities than saltstone dried out during curing and cured at high isothermal temperature.

Table 3-6. Hydraulic conductivity of samples, listed from lowest to highest final w/p ratio, cured under cell $\mathrm{K}$ and cell $\mathrm{F}$ temperature profiles

\begin{tabular}{|c|c|c|c|c|c|c|c|}
\hline \multirow{3}{*}{ Sample } & \multirow{3}{*}{$\begin{array}{l}\text { Starting } \\
\text { w/p ratio }\end{array}$} & \multirow{3}{*}{$\begin{array}{c}\text { Final w/p } \\
\text { ratio }\end{array}$} & \multirow{3}{*}{$\begin{array}{l}\text { Sample } \\
\text { Section }\end{array}$} & \multicolumn{4}{|c|}{ Hydraulic Conductivity $(\mathrm{cm} / \mathrm{s})$} \\
\hline & & & & \multicolumn{2}{|c|}{ Cell K } & \multicolumn{2}{|c|}{ Cell F } \\
\hline & & & & Saturated & $\begin{array}{c}\text { Exposed } \\
\text { Surface } \\
\end{array}$ & Saturated & $\begin{array}{c}\text { Exposed } \\
\text { Surface } \\
\end{array}$ \\
\hline \multirow{2}{*}{ WP023 } & \multirow{2}{*}{0.51} & \multirow{2}{*}{0.51} & top & $9.50 \mathrm{E}-10$ & $5.40 \mathrm{E}-10$ & 5.80E-09 & $1.00 \mathrm{E}-09$ \\
\hline & & & bottom & $1.50 \mathrm{E}-09$ & $3.70 \mathrm{E}-10$ & $7.70 \mathrm{E}-10$ & $7.20 \mathrm{E}-10$ \\
\hline \multirow{2}{*}{ WP014 } & \multirow{2}{*}{0.55} & \multirow{2}{*}{0.55} & top & $4.30 \mathrm{E}-10$ & 3.70E-09 & 1.30E-09 & $1.80 \mathrm{E}-09$ \\
\hline & & & bottom & $3.90 \mathrm{E}-10$ & 4.30E-09 & 3.70E-09 & $9.80 \mathrm{E}-10$ \\
\hline \multirow{2}{*}{ WP001 } & \multirow{2}{*}{0.59} & \multirow{2}{*}{0.59} & top & 1.70E-09 & 4.50E-09 & 1.40E-09 & 4.30E-09 \\
\hline & & & bottom & $1.90 \mathrm{E}-09$ & $3.90 \mathrm{E}-10$ & 3.60E-09 & $1.60 \mathrm{E}-09$ \\
\hline \multirow{2}{*}{ WP021 } & \multirow{2}{*}{0.53} & \multirow{2}{*}{$0.60^{\mathrm{a}, \mathrm{c}}$} & top & $1.70 \mathrm{E}-09$ & $1.70 \mathrm{E}-09$ & 4.10E-09 & $2.10 \mathrm{E}-09$ \\
\hline & & & bottom & $2.10 \mathrm{E}-09$ & 2.20E-09 & 3.70E-09 & $1.30 \mathrm{E}-09$ \\
\hline \multirow{2}{*}{ WP011 } & \multirow{2}{*}{0.57} & \multirow{2}{*}{$0.64^{\mathrm{c}}$} & top & $3.20 \mathrm{E}-08$ & $4.50 \mathrm{E}-08$ & 7.00E-09 & $1.30 \mathrm{E}-09$ \\
\hline & & & bottom & $9.60 \mathrm{E}-09$ & $1.30 \mathrm{E}-08$ & 5.00E-09 & $3.10 \mathrm{E}-09$ \\
\hline \multirow{2}{*}{ WP003 } & \multirow{2}{*}{0.67} & \multirow{2}{*}{0.67} & top & $6.20 \mathrm{E}-07$ & $4.00 \mathrm{E}-07$ & 3.50E-09 & $3.70 \mathrm{E}-09$ \\
\hline & & & bottom & 1.90E-09 & $9.80 \mathrm{E}-10$ & 3.00E-09 & $1.50 \mathrm{E}-09$ \\
\hline \multirow{2}{*}{ WP005 } & \multirow{2}{*}{0.56} & \multirow{2}{*}{$0.70^{\mathrm{a}, \mathrm{b}}$} & top & 4.30E-10 & $1.00 \mathrm{E}-09$ & 7.70E-10 & $5.20 \mathrm{E}-10$ \\
\hline & & & bottom & $3.10 \mathrm{E}-10$ & 3.30E-10 & 7.70E-10 & $5.20 \mathrm{E}-10$ \\
\hline \multirow{2}{*}{ WP010 } & \multirow{2}{*}{0.58} & \multirow{2}{*}{$0.72^{\mathrm{a}, \mathrm{b}}$} & top & $2.80 \mathrm{E}-07$ & $3.60 \mathrm{E}-09$ & 4.00E-09 & $3.10 \mathrm{E}-09$ \\
\hline & & & bottom & 3.50E-09 & 2.60E-09 & 2.20E-09 & $2.50 \mathrm{E}-09$ \\
\hline \multirow{2}{*}{ WP018 } & \multirow{2}{*}{0.73} & \multirow{2}{*}{0.73} & top & $7.80 \mathrm{E}-09$ & 8.00E-09 & 2.10E-09 & $4.50 \mathrm{E}-09$ \\
\hline & & & bottom & $2.90 \mathrm{E}-08$ & 3.30E-09 & 5.70E-09 & $7.60 \mathrm{E}-09$ \\
\hline
\end{tabular}

${ }^{a}$ Samples with admix included in the formulation

${ }^{\mathrm{b}}$ Formulation with $8 \mathrm{wt} \%$ extra water

${ }^{\mathrm{c}}$ Formulation with $4 \mathrm{wt} \%$ extra water

\subsubsection{Leachability Index}

The leachability indices ${ }^{31}$ for chromium, sodium, nitrate, and nitrite were determined for the saltstone formulations cured under the cell K profile. Note that the duplicate samples of each formulation were used to determine the leachability index and the samples were separated into two sets for convenience. 
The first set of saltstone samples was WP001-A/B, WP003-A/B, WP005-A/B, WP010-A/B, WP011-A/B, Blank-1 and the second set was WP014-A/B, WP018-A/B, WP021-A/B, WP023-A/B, Blank-2.

The ANSI/ANS 16.1 standard requires many results to be reported as part of determining the effective diffusivity and leachability index of samples; however, since many of those intermediate data are not pertinent to the results of this study, they are reported in Appendix $\mathrm{C}$ of this report. The $\mathrm{pH}$, conductivity and sodium, $\mathrm{NO}_{2}{ }^{-}$and $\mathrm{NO}_{3}{ }^{-}$concentrations for the leachate samples are given in Appendix $\mathrm{C}$. Note that the concentration of $\mathrm{Cr}$ in the leachate was below detection limits of the analytical equipment.

The ANSI/ANS 16.1 standard specifies how to calculate the effective diffusivity of a leached species when less than 20\% of the species leaches using Equation (3-1).

$$
D_{e, n}^{i}=\pi *\left[\frac{\frac{a_{n}}{A_{0}}}{(\Delta t)_{n}}\right]^{2} *\left[\frac{V}{S}\right]^{2} * T
$$

Where:

$$
\begin{aligned}
\mathrm{a}_{\mathrm{n}} & =\text { Amount of species in leachate for leaching interval } \mathrm{n}[\mathrm{g}] \\
\mathrm{A}_{0} & =\text { Total amount of species in the Saltstone Sample initially }[\mathrm{g}] \\
(\Delta \mathrm{t})_{\mathrm{n}} & =\mathrm{t}_{\mathrm{n}}-\mathrm{t}_{\mathrm{n}-1}=\text { duration of the } \mathrm{n}^{\text {th }} \text { leaching interval }[\mathrm{s}] \\
\mathrm{t}_{\mathrm{n}} & =\sum_{k=1}^{n}(\Delta t)_{n}=\text { cumulative leaching time for the } \mathrm{n}^{\text {th }} \text { leaching interval [s] } \\
D_{e, n}^{i} & =\text { Effective diffusivity of leaching species i for leaching interval } \mathrm{n}\left[\mathrm{cm}^{2} / \mathrm{s}\right] \\
\mathrm{V} & \left.=\text { Volume of cut saltstone sample [cm }{ }^{3}\right] \\
\mathrm{S} & =\text { External surface area of cut Saltstone sample }\left[\mathrm{cm}^{2}\right] \\
\mathrm{T} & =\left[\frac{1}{2} *\left(t_{n}^{1 / 2}+t_{n-1}^{1 / 2}\right)\right]^{2}=\text { Mean time of leaching interval [s] }
\end{aligned}
$$

Inserting the leachate masses at the various time intervals $\left(a_{n}\right)$, the initial species masses $\left(A_{0}\right)$, the time intervals $(\Delta t)_{n}$ and mean leaching times $(T)$, and the volume to surface area ratios (V/S) into Equation (3-1), the effective diffusivity of the leaching species for each time interval, $n$, can be calculated. Once the effective diffusivities for the $\mathrm{Cr}, \mathrm{Na}, \mathrm{NO}_{3}{ }^{-}$, and $\mathrm{NO}_{2}{ }^{-}$species for the various leaching time intervals $\left(D_{e, n}^{i}\right)$ for the saltstone samples are defined, the Leachability Index of each species $\left(\mathrm{L}_{\mathrm{i}}\right)$ can be calculated using Equation (3-2).

$$
L_{i}=\frac{1}{7} * \sum_{n=1}^{7} \log _{10}\left(\frac{1}{D_{e, n}^{i}}\right)
$$

Where:

$$
D_{e, n}^{i}=\text { Effective diffusivity of leaching species i for leaching interval } \mathrm{n}\left[\mathrm{cm}^{2} / \mathrm{s}\right]
$$




$$
\mathrm{L}_{\mathrm{i}}=\text { Leachability Index of species i [unitless] }
$$

The Leachability Index based on the ANSI 16.1 standard test for the $\mathrm{Cr}, \mathrm{Na}, \mathrm{NO}_{3}{ }^{-}$, and $\mathrm{NO}_{2}{ }^{-}$species in the saltstone samples were calculated using Equation (3-2) above using the effective diffusivities defined in Appendix C. The Leachability Indices for the saltstone samples with respect to $\mathrm{Cr}$ (both excluding and including the $\mathrm{Cr}$ in the premix) are shown in Table 3-7. The Leachability Indices for the saltstone samples with respect to $\mathrm{Na}, \mathrm{NO}_{3}{ }^{-}$and $\mathrm{NO}_{2}{ }^{-}$are shown in Table 3-8 and Table 3-9, respectively. The last column in each of these tables shows the average Leachability Indices for the various species. Detailed inputs for evaluating Equations (3-1) and (3-2) are shown in Appendix C.

Table 3-7. Leachability Index of Cr (excluding and *including Cr in Pre-mix) for saltstone cured under the cell $\mathrm{K}$ profile

\begin{tabular}{||c|c|c|c|c|c|c|c|c||}
\hline \multirow{2}{*}{ Sample } & \multirow{2}{*}{$\begin{array}{c}\text { Starting } \\
\text { w/p ratio }\end{array}$} & \multirow{2}{*}{$\begin{array}{c}\text { Final } \\
\text { w/p ratio }\end{array}$} & \multicolumn{2}{|c|}{ Excluding Cr in Premix } & \multicolumn{2}{c|}{ Including Cr in Premix } \\
\cline { 5 - 9 } & & $\mathbf{A}$ & $\mathbf{B}$ & Average & $\mathbf{A}$ & \multicolumn{2}{|c||}{ B } & Average \\
\hline \hline WP001 & 0.59 & 0.59 & $>10.0$ & $>10.0$ & $>10.0$ & $>10.6$ & $>10.6$ & $>10.6$ \\
\hline WP003 & 0.67 & 0.67 & $>10.0$ & $>10.0$ & $>10.0$ & $>10.6$ & $>10.6$ & $>10.6$ \\
\hline WP005 & 0.56 & $0.70^{\mathrm{a}, \mathrm{b}}$ & $>9.8$ & $>9.8$ & $>9.8$ & $>10.4$ & $>10.5$ & $>10.4$ \\
\hline WP010 & 0.58 & $0.72^{\mathrm{a}, \mathrm{b}}$ & $>9.8$ & $>9.9$ & $>9.9$ & $>10.5$ & $>10.5$ & $>10.5$ \\
\hline WP011 & 0.57 & $0.64^{\mathrm{c}}$ & $>9.9$ & $>9.9$ & $>9.9$ & $>10.5$ & $>10.6$ & $>10.6$ \\
\hline WP014 & 0.55 & 0.55 & $>9.9$ & $>10.0$ & $>9.9$ & $>10.6$ & $>10.6$ & $>10.6$ \\
\hline WP018 & 0.73 & 0.73 & $>10.0$ & $>10.1$ & $>10.0$ & $>10.6$ & $>10.6$ & $>10.6$ \\
\hline WP021 & 0.53 & $0.60^{\mathrm{a}, \mathrm{c}}$ & $>9.9$ & $>9.9$ & $>9.9$ & $>10.6$ & $>10.6$ & $>10.6$ \\
\hline WP023 & 0.51 & 0.51 & $>9.9$ & $>9.9$ & $>9.9$ & $>10.6$ & $>10.6$ & $>10.6$ \\
\hline
\end{tabular}

${ }^{\mathrm{a}}$ Samples with admix included in the formulation

${ }^{\mathrm{b}}$ Formulation with $8 \mathrm{wt} \%$ extra water

${ }^{\mathrm{c}}$ Formulation with $4 \mathrm{wt} \%$ extra water

*Includes $\mathrm{Cr}(\mathrm{III})$ or $\mathrm{Cr}_{2} \mathrm{O}_{3}$ in pre-mix along with salt solution $\mathrm{Cr}(\mathrm{VI})$ or $\mathrm{Na}_{2} \mathrm{CrO}_{4}$

Table 3-8. Leachability Index of Na for saltstone cured under the cell K profile

\begin{tabular}{||c|c|c|c|c|c||}
\hline Sample & $\begin{array}{c}\text { Starting } \\
\text { w/p ratio }\end{array}$ & $\begin{array}{c}\text { Final } \\
\text { w/p ratio }\end{array}$ & A & B & Average \\
\hline \hline WP001 & 0.59 & 0.59 & 7.7 & 7.8 & 7.7 \\
\hline WP003 & 0.67 & 0.67 & 7.8 & 7.9 & 7.9 \\
\hline WP005 & 0.56 & $0.70^{\mathrm{a}, \mathrm{b}}$ & 7.0 & 7.0 & 7.0 \\
\hline WP010 & 0.58 & $0.72^{\mathrm{a}, \mathrm{b}}$ & 7.6 & 7.7 & 7.7 \\
\hline WP011 & 0.57 & $0.64^{\mathrm{c}}$ & 7.2 & 7.3 & 7.3 \\
\hline WP014 & 0.55 & 0.55 & 7.7 & 8.0 & 7.8 \\
\hline WP018 & 0.73 & 0.73 & 7.1 & 7.8 & 7.4 \\
\hline WP021 & 0.53 & $0.60^{\mathrm{a}, \mathrm{c}}$ & 7.2 & 7.1 & 7.2 \\
\hline WP023 & 0.51 & 0.51 & 7.3 & 7.5 & 7.4 \\
\hline
\end{tabular}

\footnotetext{
${ }^{\mathrm{a}}$ Samples with admix included in the formulation

${ }^{\mathrm{b}}$ Formulation with $8 \mathrm{wt} \%$ extra water

${ }^{\mathrm{c}}$ Formulation with $4 \mathrm{wt} \%$ extra water
} 
Table 3-9. Leachability Index of $\mathrm{NO}_{3}{ }^{-}$and $\mathrm{NO}_{2}{ }^{-}$for saltstone cured under the cell $\mathrm{K}$ profile

\begin{tabular}{|c|c|c|c|c|c|c|c|c|}
\hline \multirow{2}{*}{ Sample } & \multirow{2}{*}{$\begin{array}{c}\text { Starting } \\
\text { w/p ratio }\end{array}$} & \multirow{2}{*}{$\begin{array}{c}\text { Final } \\
\text { w/p ratio }\end{array}$} & \multicolumn{3}{|c|}{$\mathrm{NO}_{3}{ }^{-}$} & \multicolumn{3}{|c|}{$\mathrm{NO}_{2}^{-}$} \\
\hline & & & A & B & Average & $\mathbf{A}$ & B & Average \\
\hline WP001 & 0.59 & 0.59 & 7.0 & 6.9 & 7.0 & 7.1 & 7.0 & 7.0 \\
\hline WP003 & 0.67 & 0.67 & 7.3 & 7.4 & 7.3 & 7.3 & 7.4 & 7.4 \\
\hline WP005 & 0.56 & $0.70^{\mathrm{a}, \mathrm{b}}$ & 7.0 & 6.9 & 7.0 & 7.0 & 7.0 & 7.0 \\
\hline WP010 & 0.58 & $0.72^{\mathrm{a}, \mathrm{b}}$ & 7.3 & 7.3 & 7.3 & 7.1 & 7.1 & 7.1 \\
\hline WP011 & 0.57 & $0.64^{\mathrm{c}}$ & 6.9 & 6.9 & 6.9 & 7.3 & 7.3 & 7.3 \\
\hline WP014 & 0.55 & 0.55 & 7.3 & 7.5 & 7.4 & 7.3 & 7.5 & 7.4 \\
\hline WP018 & 0.73 & 0.73 & 6.6 & 7.3 & 7.0 & 6.7 & 7.4 & 7.0 \\
\hline WP021 & 0.53 & $0.60^{\mathrm{a}, \mathrm{c}}$ & 6.8 & 6.6 & 6.7 & 6.9 & 6.7 & 6.8 \\
\hline WP023 & 0.51 & 0.51 & 6.8 & 7.0 & 6.9 & 6.8 & 7.1 & 6.9 \\
\hline
\end{tabular}

${ }^{\mathrm{a}}$ Samples with admix included in the formulation

${ }^{\mathrm{b}}$ Formulation with $8 \mathrm{wt} \%$ extra water

${ }^{\mathrm{c}}$ Formulation with $4 \mathrm{wt} \%$ extra water

The Leachability Indices for $\mathrm{Na}$ ranged from 7.0 to 7.9. The Leachability Indices for $\mathrm{NO}_{3}{ }^{-}$and $\mathrm{NO}_{2}{ }^{-}$ ranged from 6.9 to 7.4. A smaller the Leachability Index indicates that a constituent is more easily removed from the saltstone. Based on the formulations tested in this study, the initial formulation of the samples did not influence the rate at which contaminants were released from the saltstone. However, comparing these results to samples that were dried out, the curing environment may have an impact on the leachability of some constituents in saltstone. Based on results from another study, samples that were dried out leached more $\mathrm{NO}_{3}{ }^{-}$and $\mathrm{NO}_{2}{ }^{-}$than the samples that were kept in a moist environment. ${ }^{40}$ 


\subsection{Conclusions}

Data from a typical (no setbacks or process upsets) processing day at the SPF was analyzed to calculate instantaneous and cumulative saltstone water to premix ratios over the given period of processing. A series of saltstone formulations were developed and analyzed based on these data. The fresh properties (gel, set time, bleed, viscosity, yield stress) and cured properties (hydraulic conductivity, porosity, density, and contaminant retention) of these formulations were analyzed.

The first objective of this study was to analyze saltstone fresh properties to determine the feasibility of reducing the formulation w/p ratio and while varying the amount of extra water and admixtures used during processing at the SPF. The $8 \mathrm{wt} \%$ extra water in the formulation causes saltstone to generate more bleed water as it cures than the samples with $4 \mathrm{wt} \%$ extra water or salt solution only since the water dilutes the salt solution molarity, delaying the reaction of the slag and fly ash. Adding extra water to the formulations with w/p ratios of 0.58 or lower does not increase the set time past three days and the bleed water is reabsorbed after three days, therefore, only considering the properties of bleed water and set time, it is feasible to process w/p ratios below 0.58 by adding extra water or admix. Adding Daratard to w/p ratios greater than 0.66 causes long set times and in some cases, standing bleed water after three days; therefore its use should be limited or avoided at these formulations.

The gel time is affected by extra water, even at the low w/p ratios. Saltstone formulations with low w/p ratios ( 0.56 or lower) without any admixture or extra water, gel too quickly ( $<20 \mathrm{~min}$ ) to ensure reliable processing through the facility. However, if admix is used in these formulations, the gel time is extended into the acceptable range of 20 - 60 minutes. Adding $8 \mathrm{wt} \%$ extra water to the low w/p formulations increases the gel time past 60 minutes. Therefore, for gel time it may be feasible to use Daratard to process low w/p ratios as long as the dosage is very well controlled and can remain at $0.05 \mathrm{wt} \%$; however, using 8 wt \% extra water extends the gel time past the acceptable limits for these formulations. The vane rheology method for determining the gel time of a sample provides insight into the structure development of the sample; however it is difficult to distinguish the gel time from settling or other reactions based on the results obtained thus far. If this method is further developed, it could be less subjective than the pour test and provide more understanding into the hydration and structure development of fresh saltstone.

Based on the fresh property data presented in this report, mixes with w/p ratios in the range of $0.57-0.66$ formulated with $4 \mathrm{wt} \%$ extra water or salt solution only, produce fresh saltstone grout that satisfies acceptance criteria for set time, bleed, gel, and rheology. All of the formulations with $8 \mathrm{wt} \%$ extra water or formulations with w/p ratios above 0.65 that include Daratard have fresh properties outside the acceptance criteria.

The second part of this study was to provide information for understanding the impact of curing conditions (cure temperature, relative humidity $(\mathrm{RH})$ ) and processing formulation on the performance properties of cured saltstone. Samples were cured under profiles based on temperature data from cell K and cell F in SDU 4. Half of the samples were kept under saturated conditions by adding liquid on top of the grout to maintain complete saturation. The other half had the grout surface exposed to the humid environment. Based on the results of this study, the relative humidity of the curing environment has the most impact on the performance (cured) properties of saltstone. If the drying of the sample is eliminated or at least minimized, higher cure temperatures can be beneficial for saltstone due to increased reaction rates, formation of denser hydration products, and reduction in porosity.

The final w/p ratio of the saltstone formulation does affect the density, porosity, and compressive strength of the cured saltstone. The saltstone formulations with $0.59 \mathrm{w} / \mathrm{p}$ ratios and lower had higher densities, lower porosities, and higher compressive strength than samples formulated at a higher $\mathrm{w} / \mathrm{p}$ ratio. There is a general trend that the samples formulated at high w/p ratios (0.67 and higher) have the lowest density, 
highest porosity and lowest strength. However, compared to data from previous studies, the density, porosity, and compressive strength of saltstone are more controlled by curing in a high humidity environment rather than the w/p ratio of the saltstone formulation. The Leachability index for $\mathrm{Na}, \mathrm{NO}_{3}{ }^{-}$ and $\mathrm{NO}_{2}{ }^{-}$were calculated for the cured samples using the ANS/ANSI 16.1 standard. Based on the formulations tested in this study, the initial formulation of the samples did not affect the rate at which contaminants are released from the saltstone.

Samples cured for 28 days in controlled humidity environments under temperature profiles up to 55 and $80^{\circ} \mathrm{C}$ had hydraulic conductivities of $4.5 \mathrm{E}-8$ to $4.3 \mathrm{E}-10 \mathrm{~cm} / \mathrm{s}$. On average, the cell $\mathrm{K}$ samples had slightly higher hydraulic conductivities for samples at higher w/p ratios than the cell F samples; however, the majority of the samples have hydraulic conductivities within the range of E-9 or E-10 cm/s. Of the 72 samples analyzed, only three samples had hydraulic conductivities on the order of $2.8 \mathrm{E}-7 \mathrm{~cm} / \mathrm{s}$. In a previous study, samples cured isothermally in an uncontrolled environment had hydraulic conductivities ranging from $1.04 \mathrm{E}-9$ to $1.90 \mathrm{E}-6 \mathrm{~cm} / \mathrm{s}$, with the majority of the $60{ }^{\circ} \mathrm{C}$ samples having hydraulic conductivities greater than $1.0 \mathrm{E}-7 \mathrm{~cm} / \mathrm{s}$. Comparing the results presented in this study to the results from the previous study, the curing conditions have a greater effect on the hydraulic conductivity of saltstone than the w/p ratio. The saltstone in the current study was cured in a high humidity environment which allowed the microstructure to develop without being dehydrated, reducing the formation of microcracks. Therefore, the combination of curing saltstone in a saturated or high humidity environment and under a ramped temperature profile results in slower hydraulic conductivities than saltstone dried out during curing and cured at high isothermal temperatures. 


\subsection{Recommendations, Path Forward or Future Work}

The formulations used in this study represent instantaneous water to premix ratios that are processed through the SPF. While these formulations provide valuable insight into the properties of fresh and cured saltstone, it is not representative of the entire bulk of material in the SDU. Therefore, a scaled Saltstone Facility should be used to examine cumulative effects of flush water and varying w/p ratios of a saltstone formulation throughout a day of processing. The material produced using the scaled facility can be cured in a humid environment (using saturated conditions and an exposed surface) under a temperature profile to mimic the conditions recorded in the SDU. The hydraulic conductivity and other cured properties of these samples should be measured. 


\subsection{References}

1. Bricker, J.M., "Routine Saltstone Support - FY2012," Savannah River Remediation, HLW-SSFTTR-2012-0003 Revision 0, October 19, 2011.

2. $\quad$ Reigel, M.M., "Recommended Saltstone Formulation for the Second Quarter 2011," Savannah River National Laboratory, Aiken, SC, SRNL-L3100-2011-00121 Revision 0, June 10, 2011.

3. $\quad$ Reigel, M.M., "Recommended Saltstone Formulation for Facility Restart after ELAWD Outage," Savannah River National Laboratory, SRNL-L3100-2012-00089, June 25, 2012.

4. Dixon, K.L., Harbour, J.R., and Phifer, M.A., "Hydraulic and Physical Properties of Saltstone Grouts and Vault Concretes," Savannah River National Laboratory, SRNL-STI-2008-00421, Revision 0, November 2008.

5. Dixon, K.L., Harbour, J.R., and Phifer, M.A., "Hydraulic and Physical Properties of ARP/MCU Saltstone Grout," Savannah River National Laboratory, SRNL-STI-2009-00419, Revision 0, May 2010 .

6. Harbour, J.R., Edwards, T.B., and Williams, V.J., "Key Factors that Influence the Performance Properties of ARP/MCU Saltstone Mixes," Savannah River National Laboratory, SRNL-STI2009-00546, September 2009.

7. Harbour, J.R., Edwards, T.B., and Williams, V.J., "Impact of Time/Temperature Curing Conditions and Aluminate Concentration on Saltstone Properties," Savannah River National Laboratory, SRNL-STI-2009-00184, Revision 0, 2009.

8. $\quad$ Reigel, M.M., Edwards, T.B., and Pickenheim, B.R., "Operational and Compositional Factors that Affect the Performance Properties of ARP/MCU Saltstone Grout," Savannah River National Laboratory, SRNL-STI-2011-00665, February 2012.

9. Hansen, E.K., "Physical Characterization of FY2004 Saltstone Simulant Slurries," Savannah River National Laboratory, WSRC-TR-2005-00365, Revision 0, December 2005.

10. Langton, C.A., "Initial Tank 50 Batch 1 Saltstone Formulation Recommendation," WSRC-TR2007-00042, Revision 0, February 5, 2007.

11. Langton, C.A. and Burket, P.R. and Hansen, E.K. and Herman, D.T., et al., "Tank 50 Batch 0 Saltstone Formulation Testing," Savannah River National Laboratory, WSRC-TR-2005-00498, January 30, 2006.

12. Langton, C.A., Hansen, E.K., Burket, P.R., Marsh, D.M., et al., "Tank 50 Batch 0 Saltstone Formulation Reconfirmation Using Samples Collected in September 2006," Savannah River National Laboratory, WSRC-TR-2006-00226, Revision 0, November 5, 2006.

13. Reigel, M.M. and Clark, E.A., "Evaluation of Saltstone Sheet Drain Perfromance," Savannah River National Laboratory, SRNL-L3100-2011-00156 Rev. 0, July 29, 2011.

14. Staub, A.V., "Estimation of Variability in the Saltstone Production Process and Path Forward," Washington Savannah River Company, LWO-WSE-2008-00015, February 4, 2008. 
15. Reigel, M.M., "Analysis of the Solids Collected from the Drain Water Return Piping, August 2011," Savannah River National Laboratory.

16. Bricker, J.M., "Properties of Various Water to Premix Ratios," Savannah River Remediation, HLW-SSF-TTR-2012-0004, Octopber 19, 2011.

17. Pickenheim, B.R. and Reigel, M.M., "Task Technical and Quality Assurance Plan for Analyzing the Effects of Processing and Curing Conditions on Saltstone," Savannah River National Laboratory, SRNL-RP-2012-00025, May 2012.

18. Smith, F.M., "PA Property Testing of Saltstone Produced in the SPF Operating Window," Savannah River Remediation, HLW-SSF-TTR-2012-0012, Revision 1, April 2012.

19. "Performance Assessment for the Saltstone Disposal Facility at the Savannah River Site " Savannah River Remediation Cosure \& Waste Disposal Authority, SRR-CWDA-2009-00017, October 2009.

20. Cozzi, A.D., "Saltstone 3QCY08 TCLP Results," Savannah River National Laboratory, SRNLSTI-2009-00208, Revision 0, April 2009.

21. Reigel, M.M., "Saltstone 3QCY09 TCLP Results," Savannah River National Laboratory, SRNLSTI-2009-00688, Revision 1, November 2009.

22. Bannochie, C.J., "Results for the First Quarter 2012 Tank 50 WAC Slurry Sample: Chemical and Radionculide Contaminant Results," Savannah River National Laboratory, SRNL-STI-201200286, June 2012.

23. "Standard Test Methods for Time of Setting of Hydraulic Cement by Vicat Needle," ASTM International, ASTM C 191 - 08.

24. "Standard Test Method for Flow Consistency of Controlled Low Strength Material (CLSM)," ASTM International, ASTM D 6103 - 04.

25. "Standard Test Methods for Measurement of Hydraulic Conductivity of Saturated Porous Materials Using a Flexible Wall Permeameter," ASTM International, ASTM D5084 - 10 (Method F).

26. Mehta, P.K. and Monteiro, P.J.M., Concrete: Microstructure, Properties, and Materials, Third ed. McGraw-Hill.

27. Dixon, K.L., "Moisture Retention Properties of High temperature Cure ARP/MCU Saltstone Grout," Savannah River National Laboratory, SRNL-STI-2011-00661, October 2011.

28. Dixon, K.L., Harbour, J.R., and Phifer, M.A., "Hydraulic and Physical Properties of Saltstone Grout," Savannah River National Laboratory, SRNL-STI-2009-00419, Revision 0, May 2010.

29. "Standard Test Method for Compressive Strength of Cylindrical Concrete Speciments," ASTM International, ASTM C39/C39M - 12. 
30. Harbour, J.R., Williams, V.J., Edwards, T.B., and Eibling, R.E., "Saltstone Variability Study Measurement of Porosity," Savannah River National Laboratory, WSRC-STI-2007-00352, Revision 0, July 2007.

31. "American National Standard: Measurement of the Leachability of Solidified Low-level Radioactive Wastes by a Short-term Test Procedure," American Nuclear Society, ANSI/ANS16.1-2003, July 7, 2003.

32. Burns, G.L., "Saltstone Facility Operating Procedure: Saltstone Grout Lab Analysis ", 704-Z4400, Revision 11, March 27, 2002.

33. Biernacki, J.J. and Richardson, J.M., "Kinetics of Slag Hydration in the Presence of Calcium Hydroxid," J. Am. Ceram. Soc., 85, [9] 2261-7 (2002).

34. Escalante-Garcia, J.I., Fuentes, A.F., Gorokhovsky, A., Fraire-Luna, P.E., et al., "Hydration Products and Reactivity of Blast-Furnace Slag Activated by Various Alkalis," J. Am. Ceram. Soc., 86, [12] 2148-53 (2003).

35. Utton, C.A., Hayes, M., Hill, J., Milestone, N.B., et al., "Effect of Temperatures up to $90^{\circ} \mathrm{C}$ on the Early Hydration of Portland-Blastfurnace Slag Cements," J. Am. Ceram. Soc., 91, [3] 948-54 (2008).

36. Ma, W. and Brown, P.W., "Hydrothermal Reactions of Fly Ash with $\mathrm{Ca}(\mathrm{OH})_{2}$ and $\mathrm{CaSO}_{4}-2 \mathrm{H}_{2} \mathrm{O}$," Cem. Concr. Res., 27, [8] 1237-48 (1997).

37. Brough, A.R. and Katz, A. and Sun, G.-K. and Struble, L.J., et al., "Adiabatically cured, alkaliactivated cement-based wasteforms contaiing high leveles of fly ash, Formation of zeolites and Al-substituted C-S-H," Cem. Concr. Res., 31, 1437-47 (2001).

38. Harbour, J.R. and Williams, M.F., "Impact of Curing Temperature on the Saturated Liquid Permeability of Saltstone," Savannah River National Laboratory, SRNL-STI-2010-00745, Revision 0, February 2011.

39. Taylor, H.F.W., Cement Cemistry, Second ed. Thomas Telford Publishing, London, England, 1997.

40. Cozzi, A.D. and Pickenheim, B.R., "Impact of Pouring into Standing Water," Savannah River National Laboratory, September 2012. 
SRNL-STI-2012-00558

Revision 0

Appendix A. SDU Temperature Profiles and Facility Processing Data 


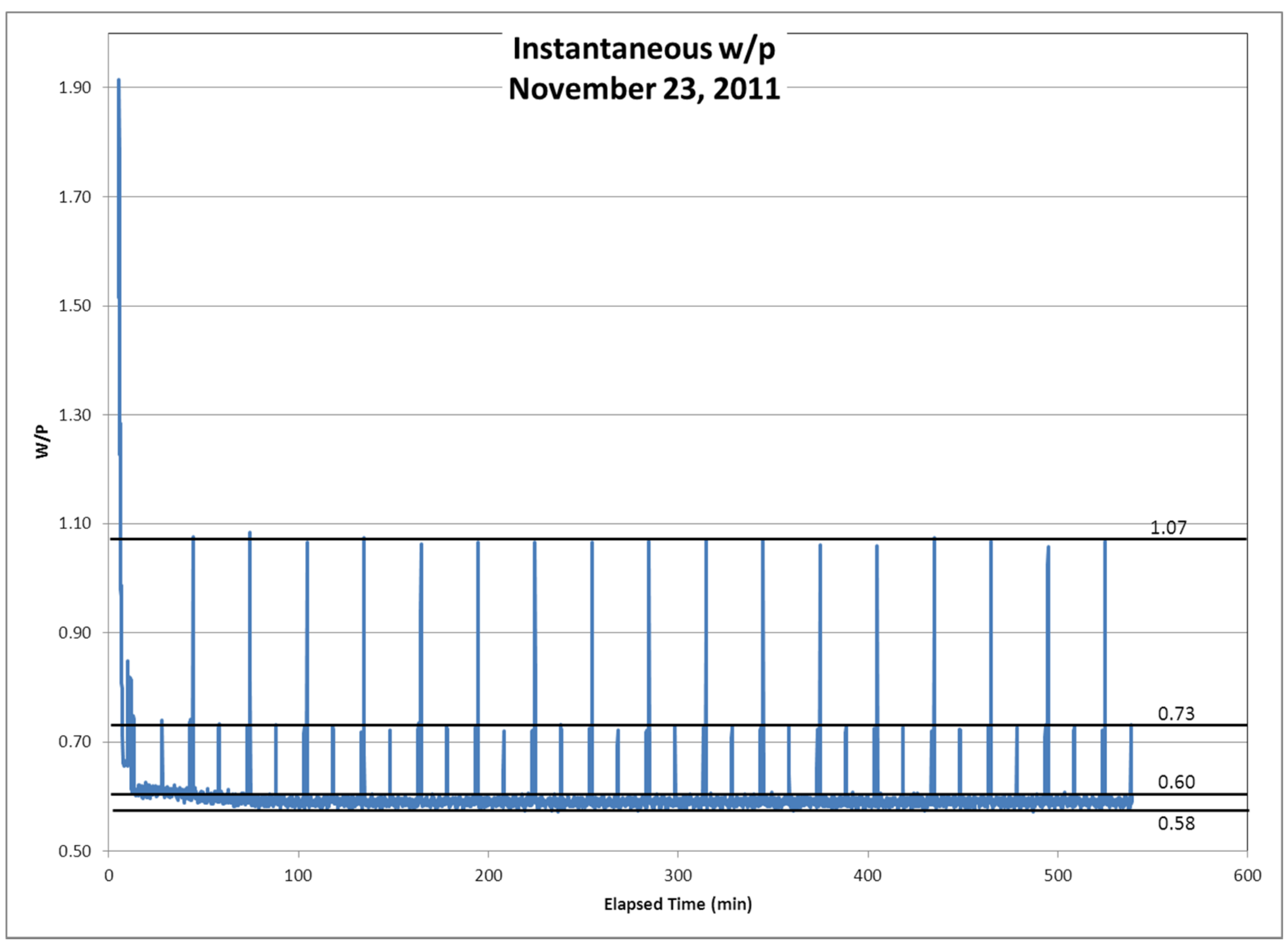




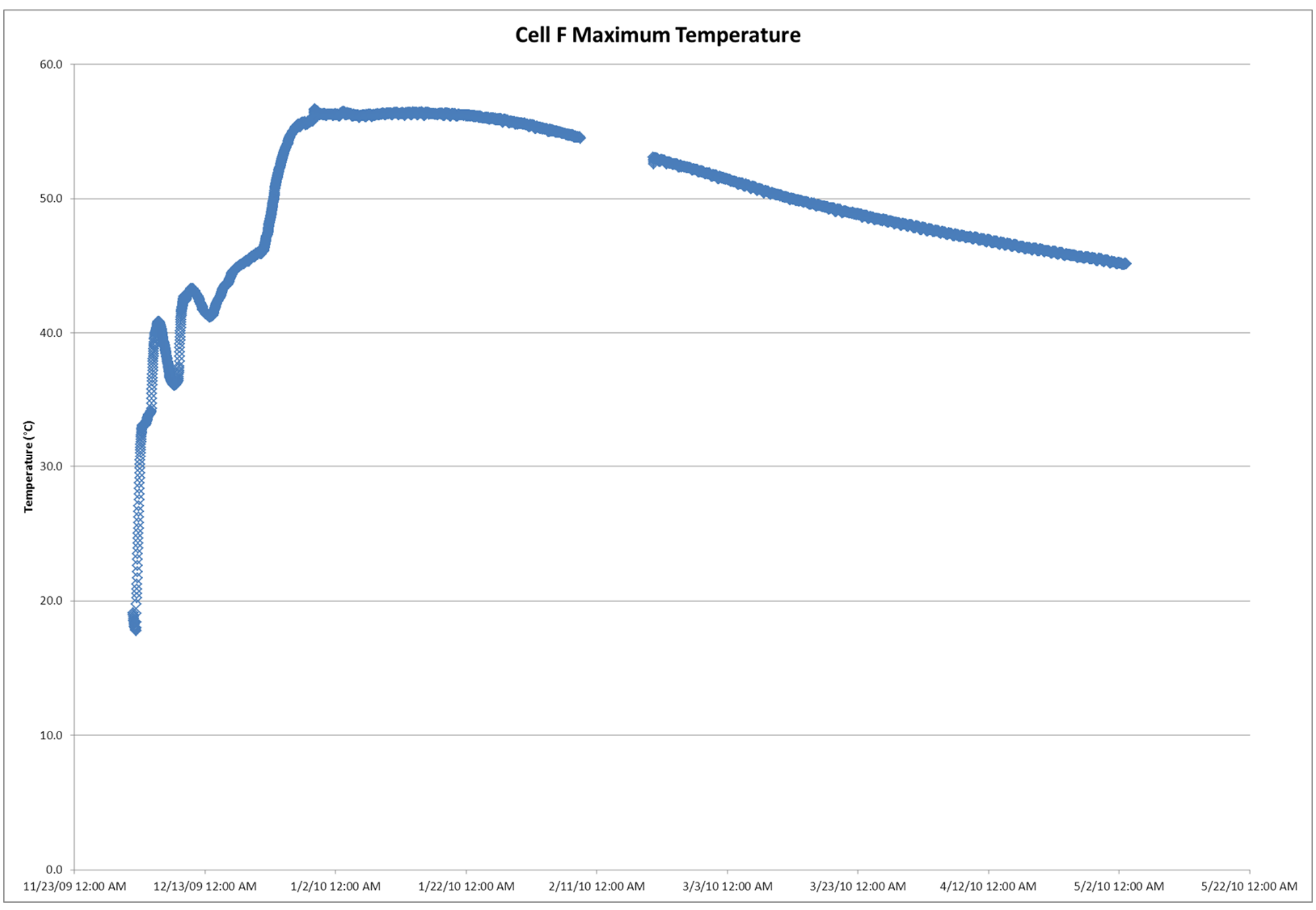


SRNL-STI-2012-00558

Revision 0

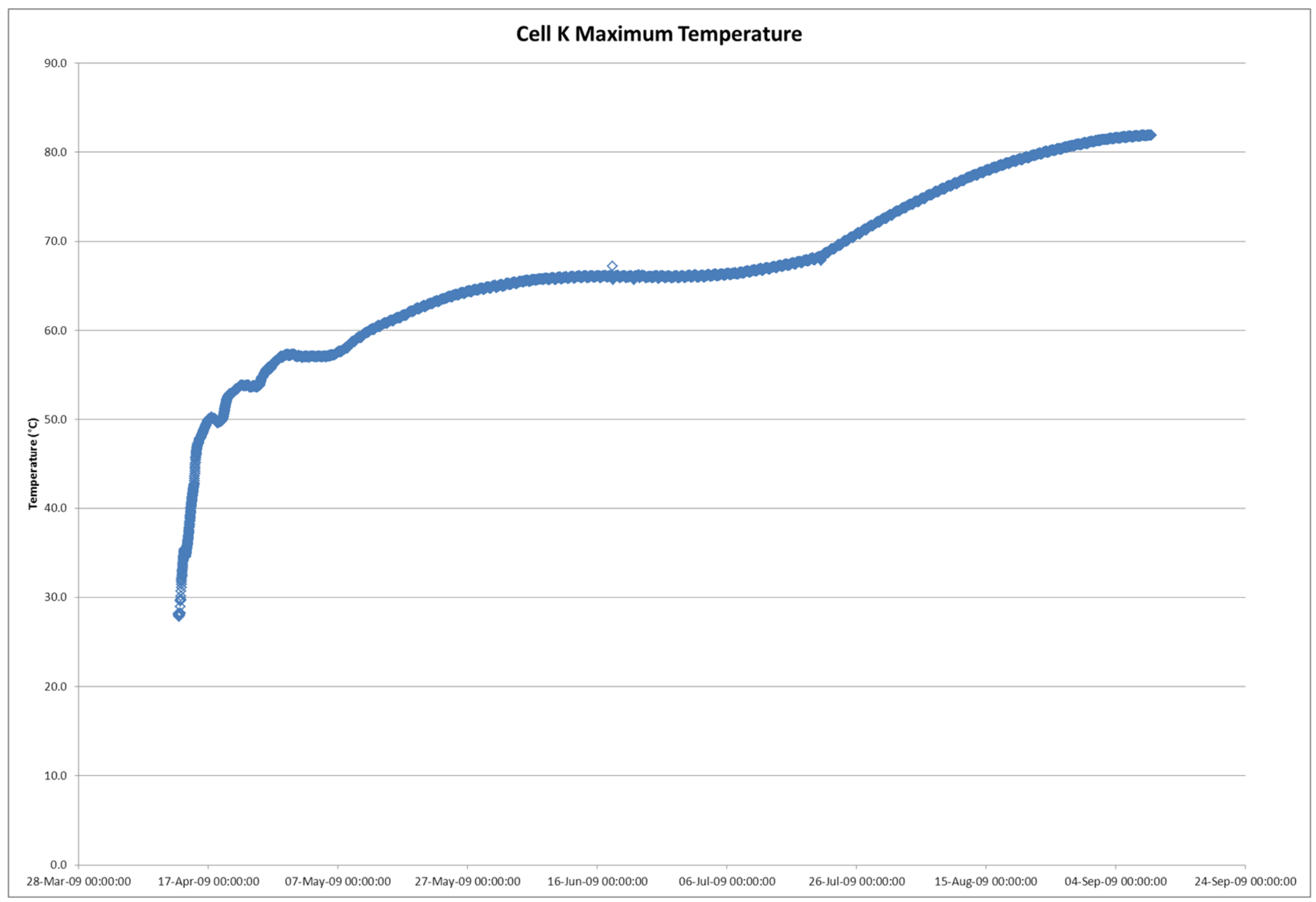

A-4 
SRNL-STI-2012-00558

Revision 0

Appendix B. Vane Rheology Results 
The results of the vane rheology measurements are shown in this appendix. The gel time for each sample is marked with an " $\mathrm{X}$ " and recorded in Table 2-1.
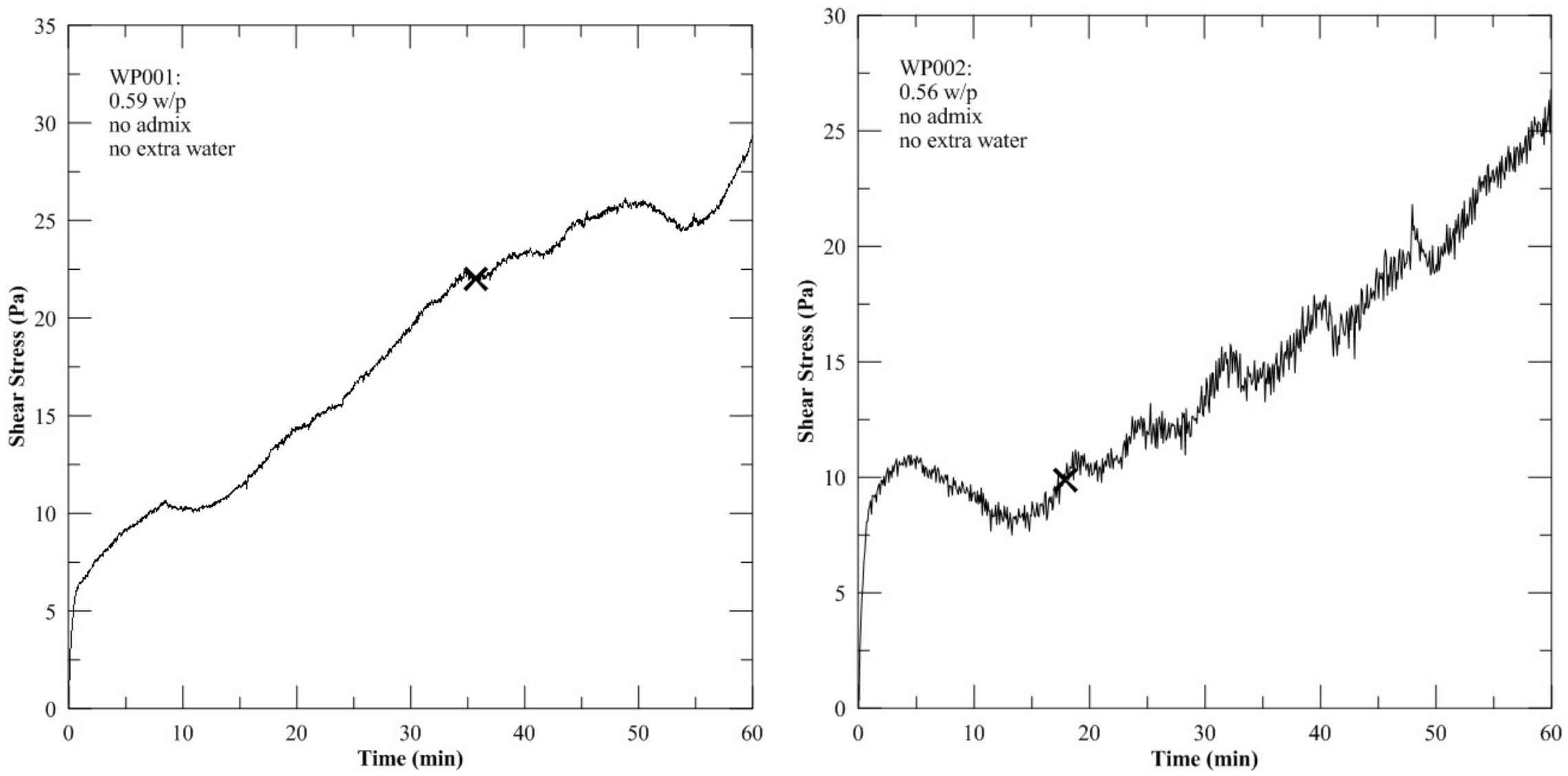

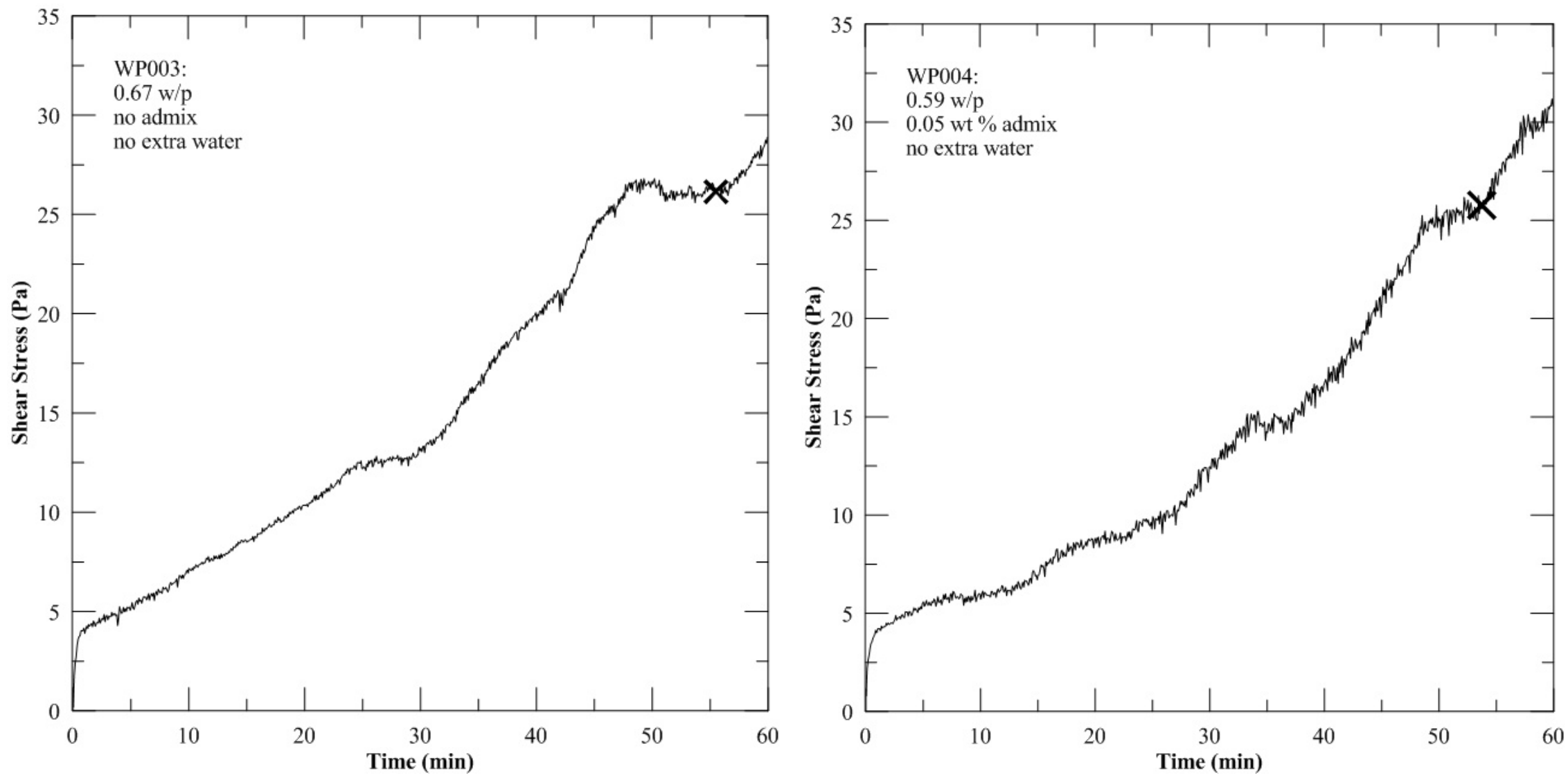
SRNL-STI-2012-00558

Revision 0
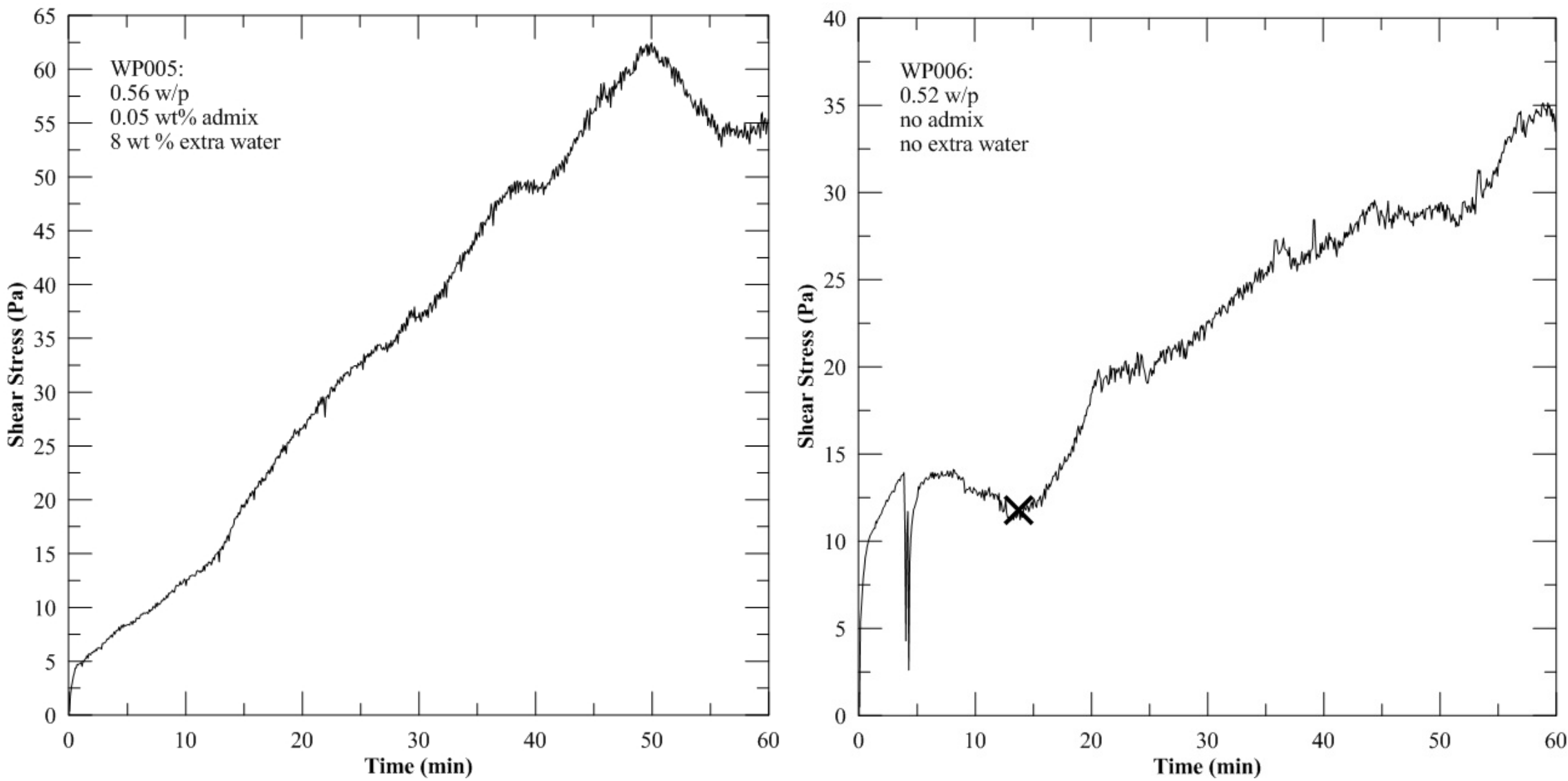

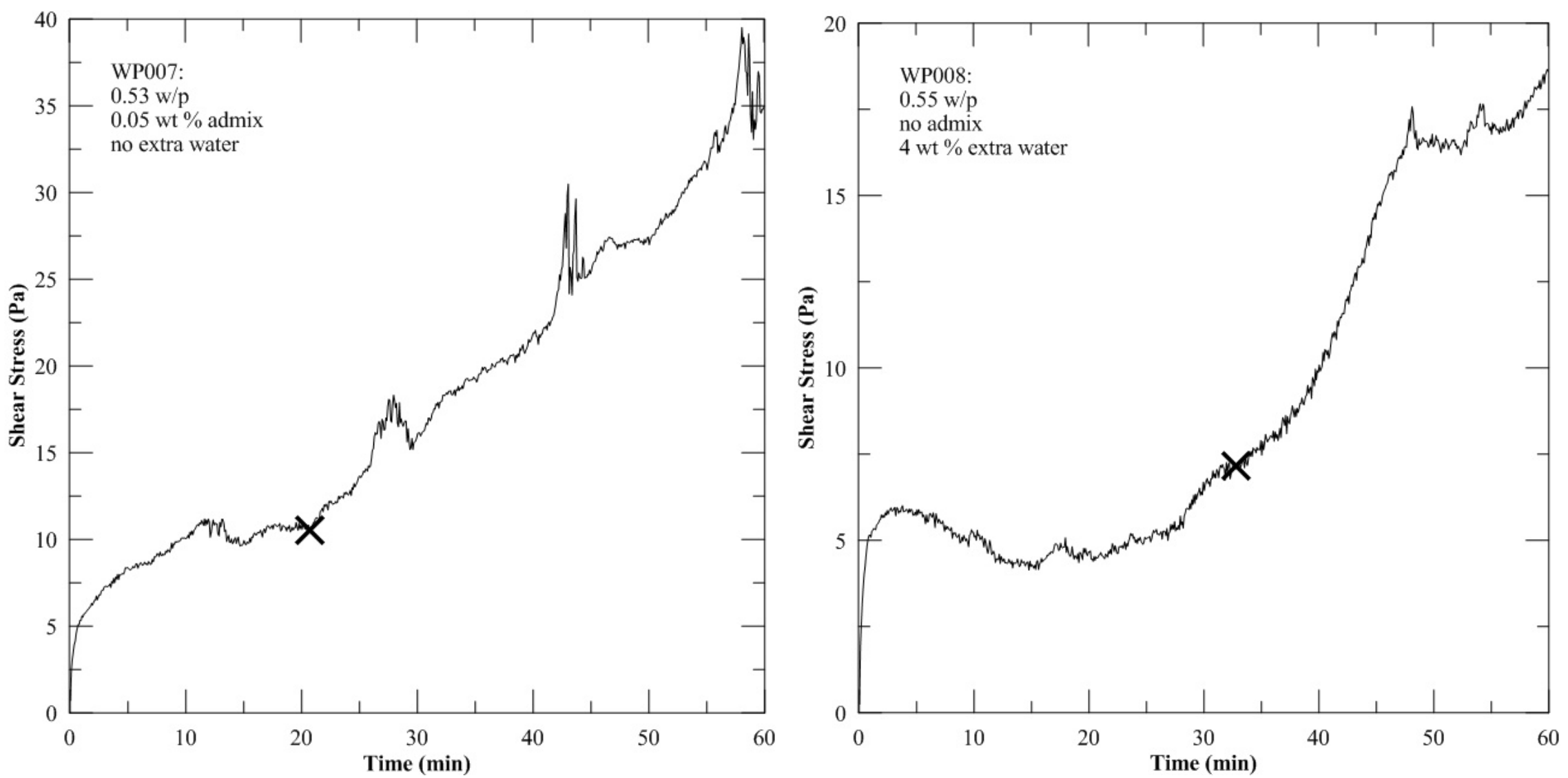

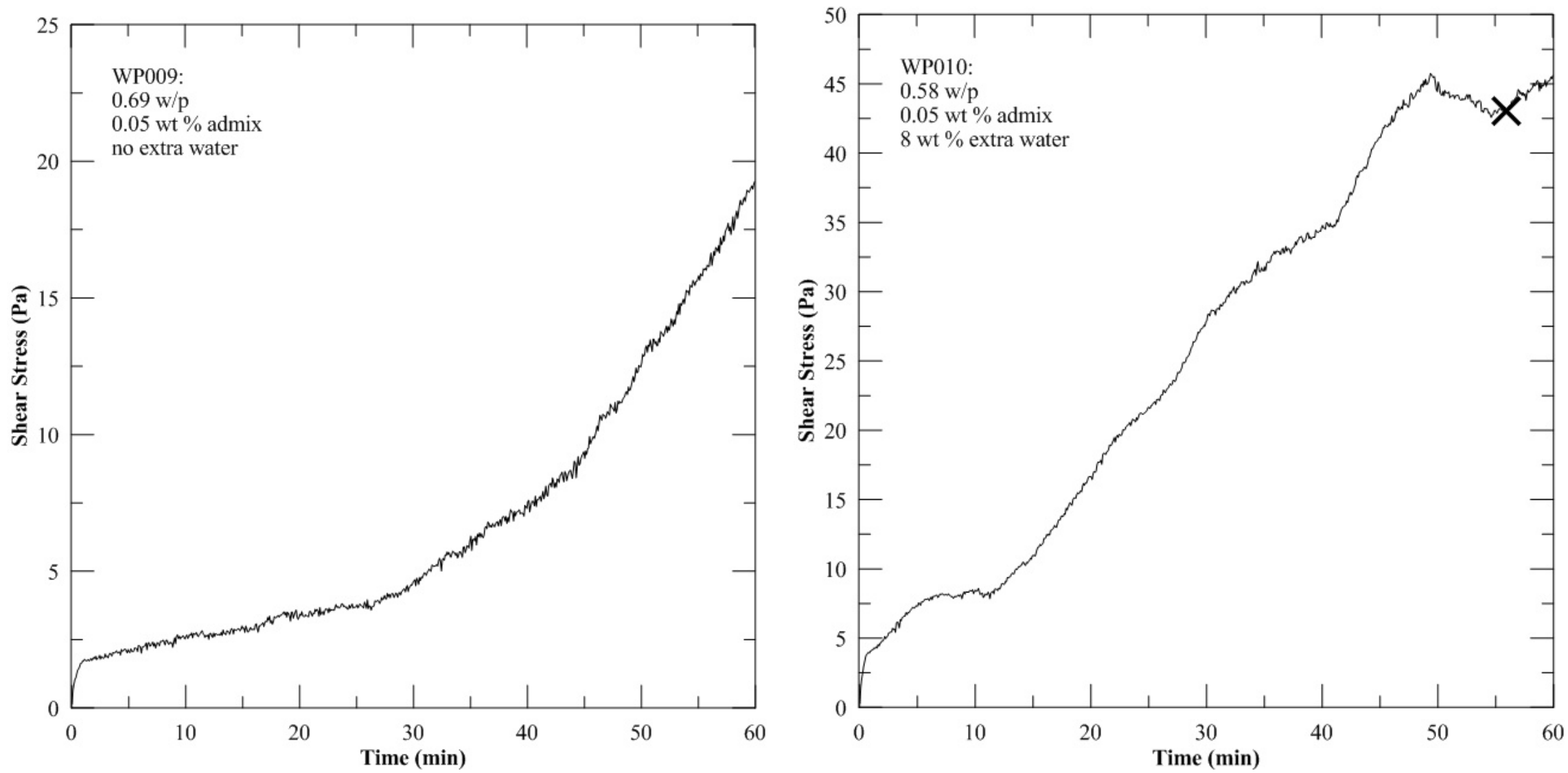

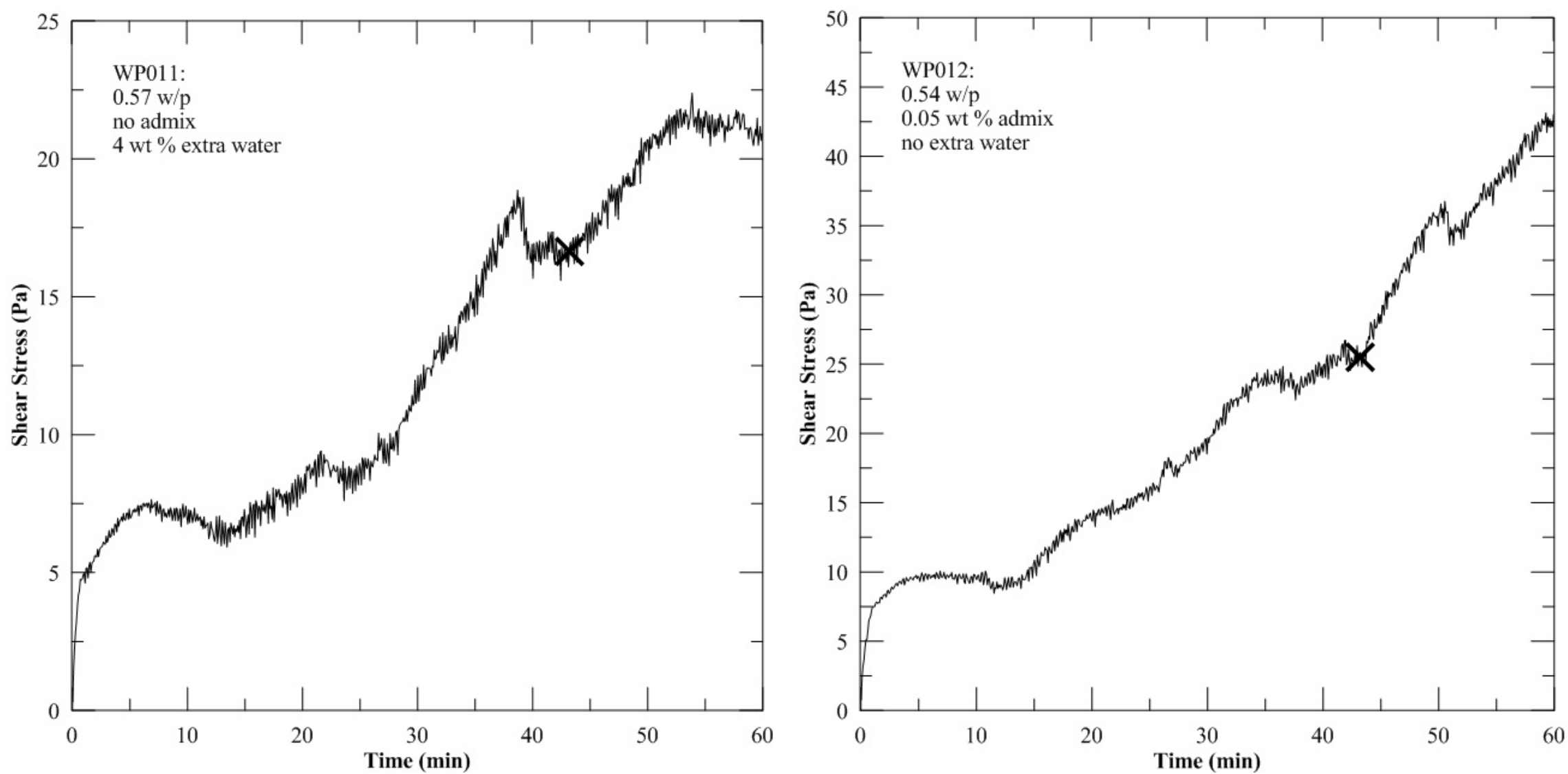

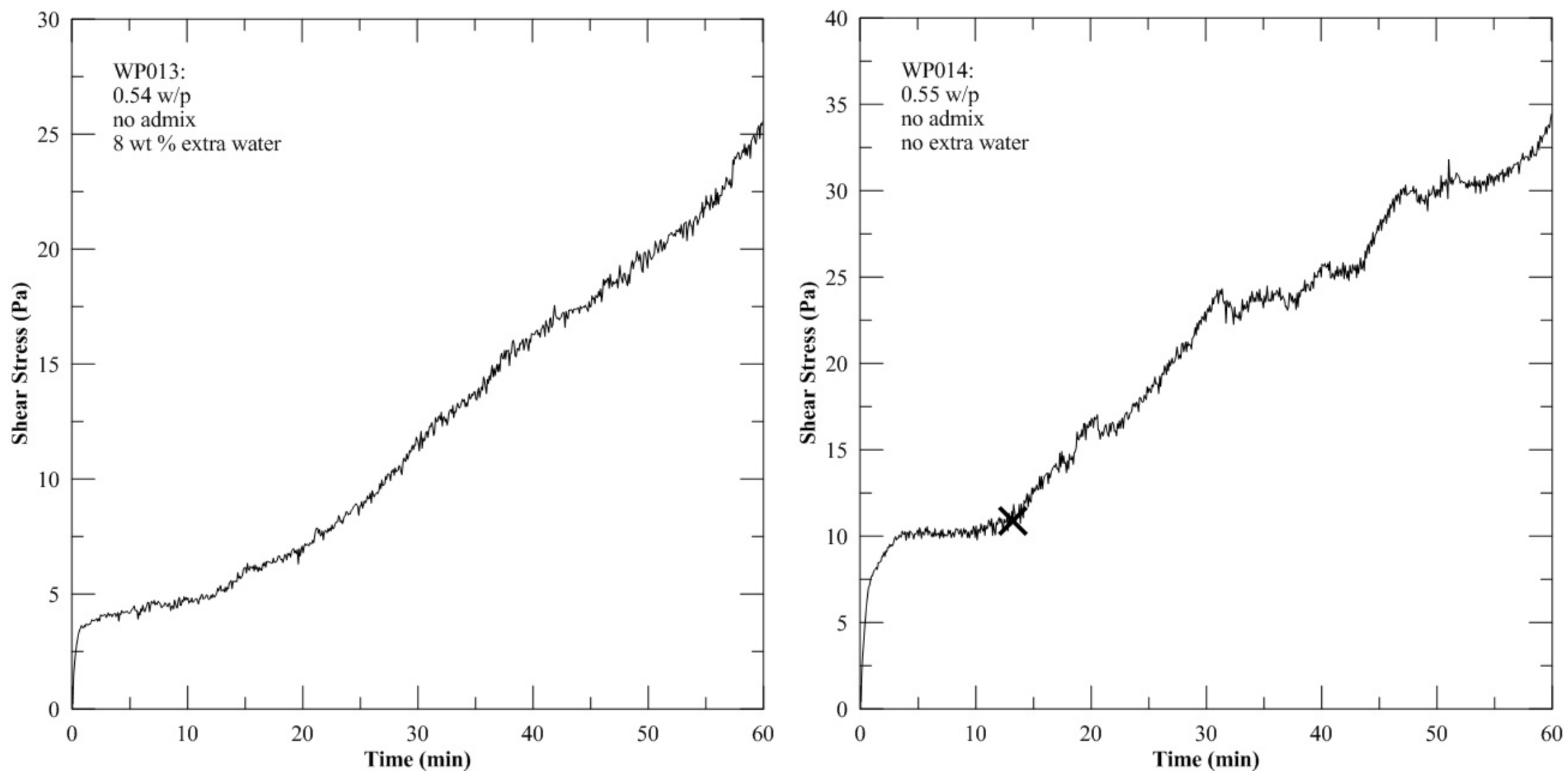

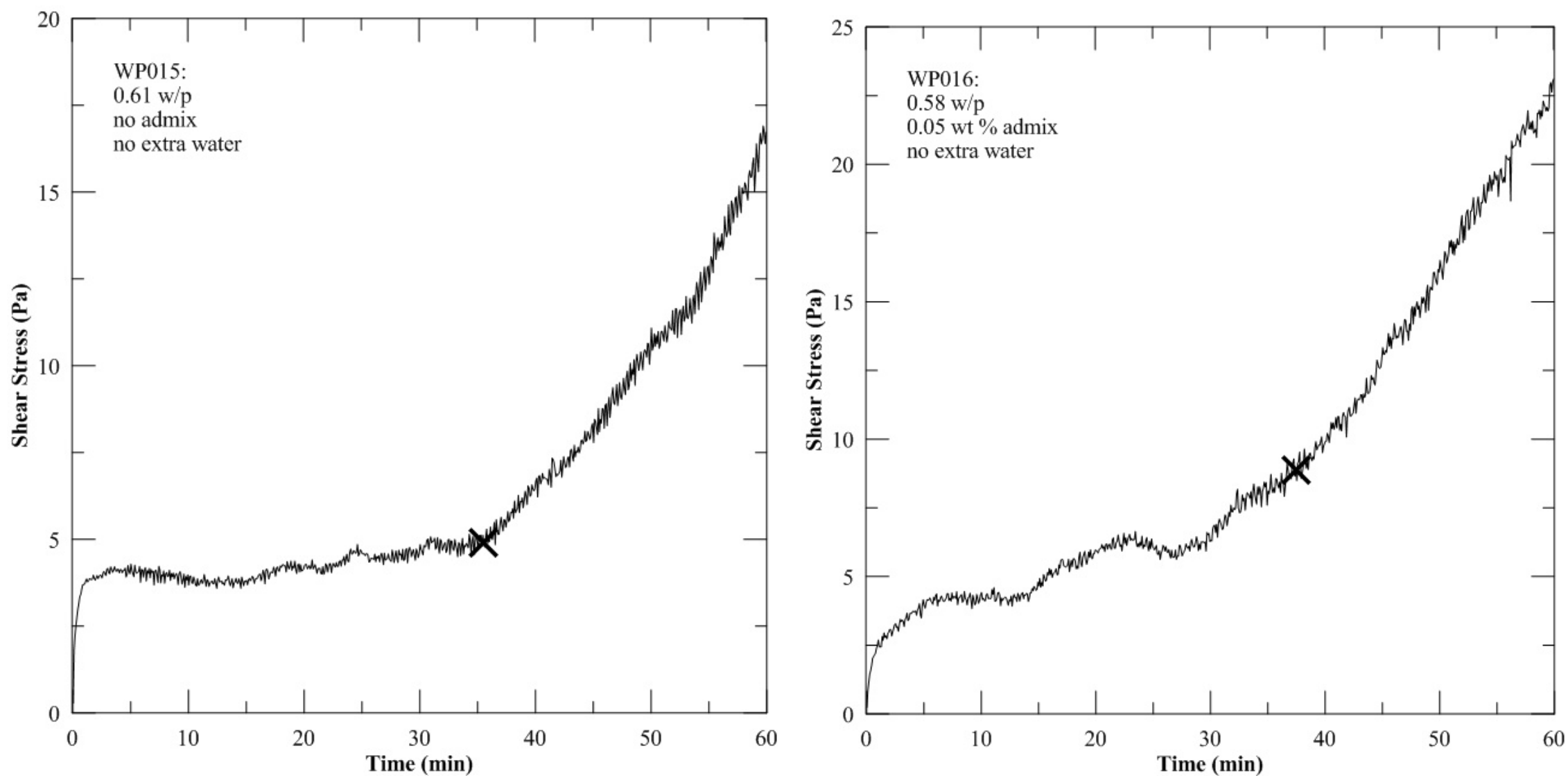

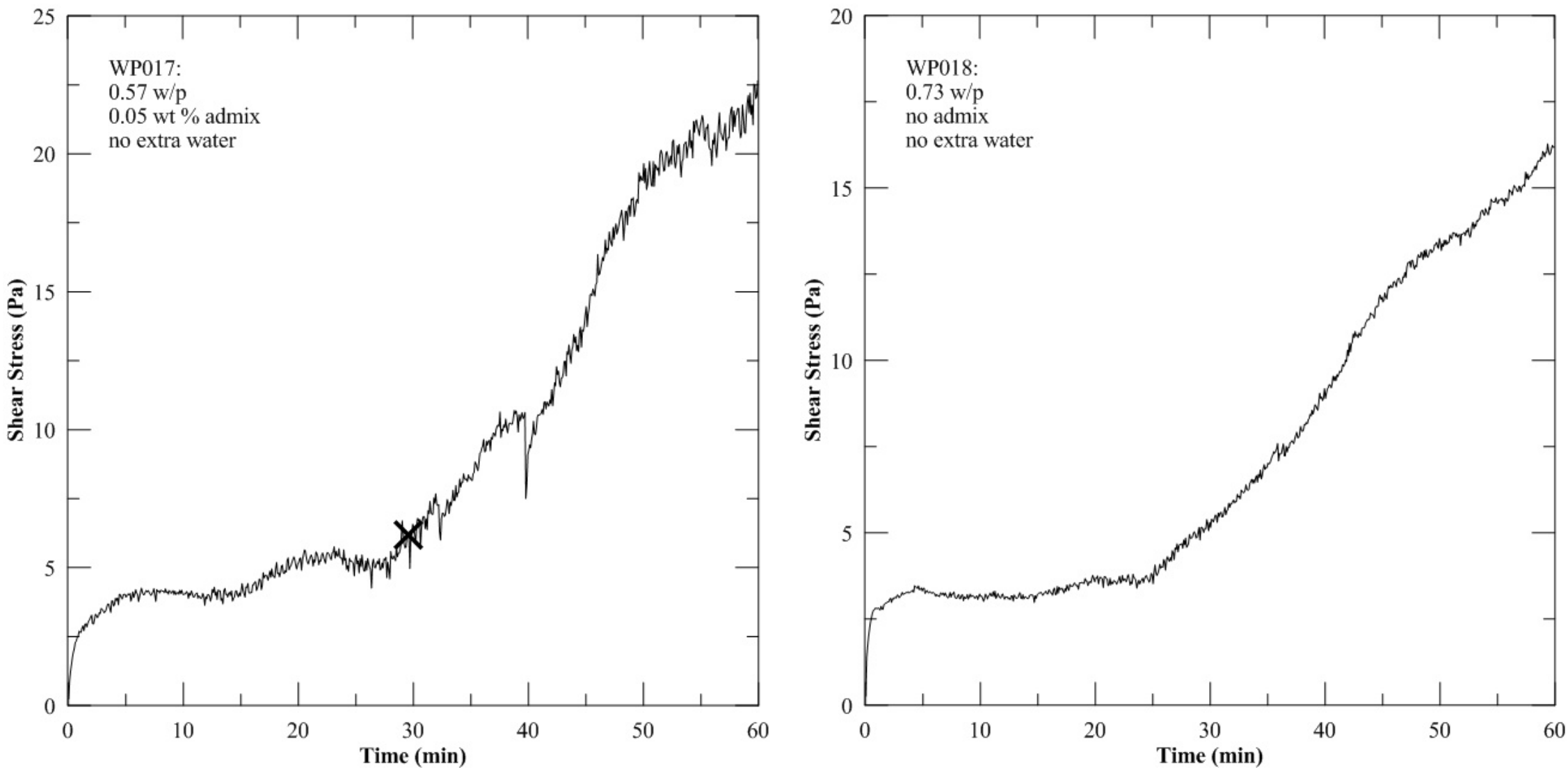

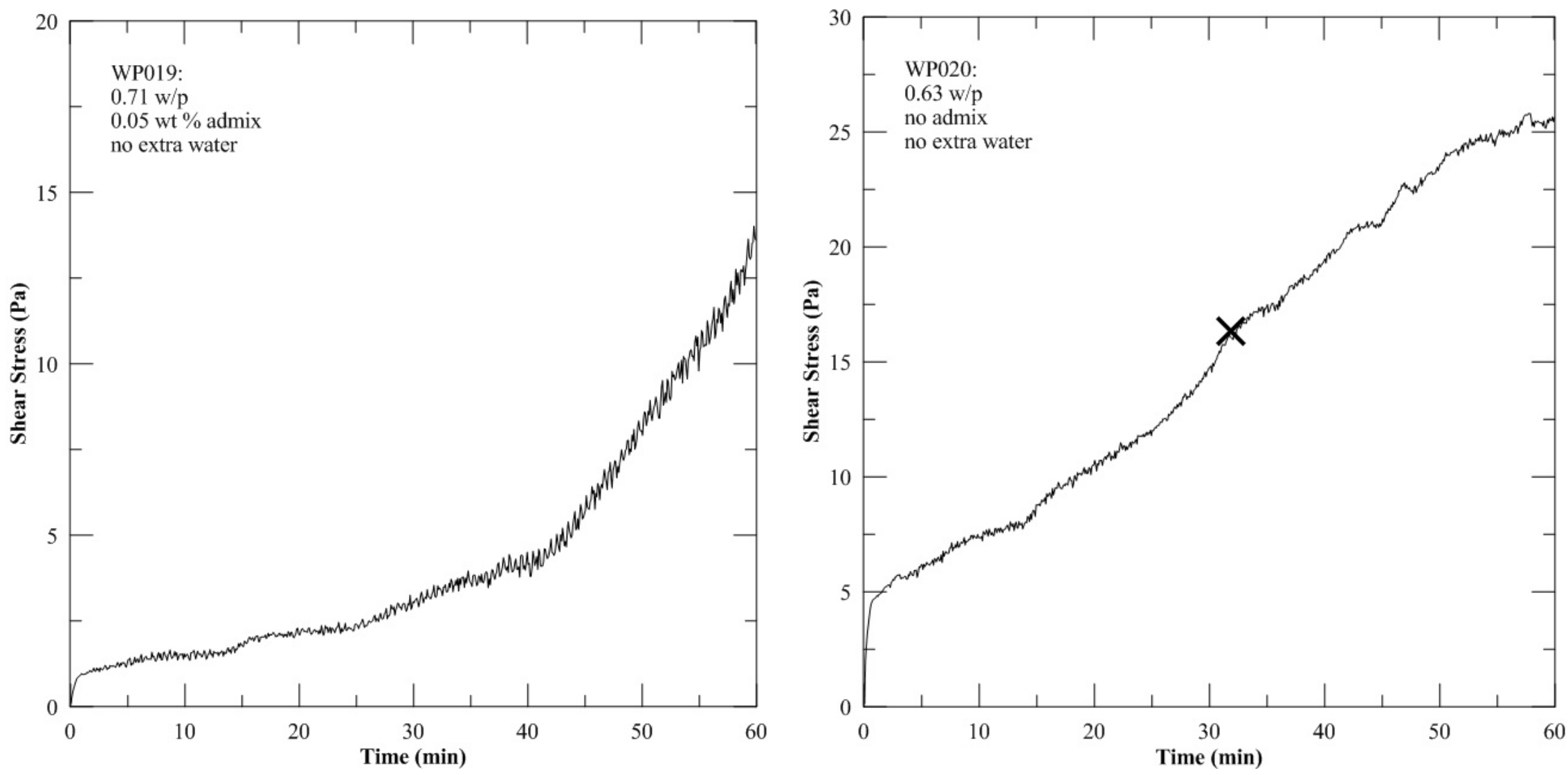

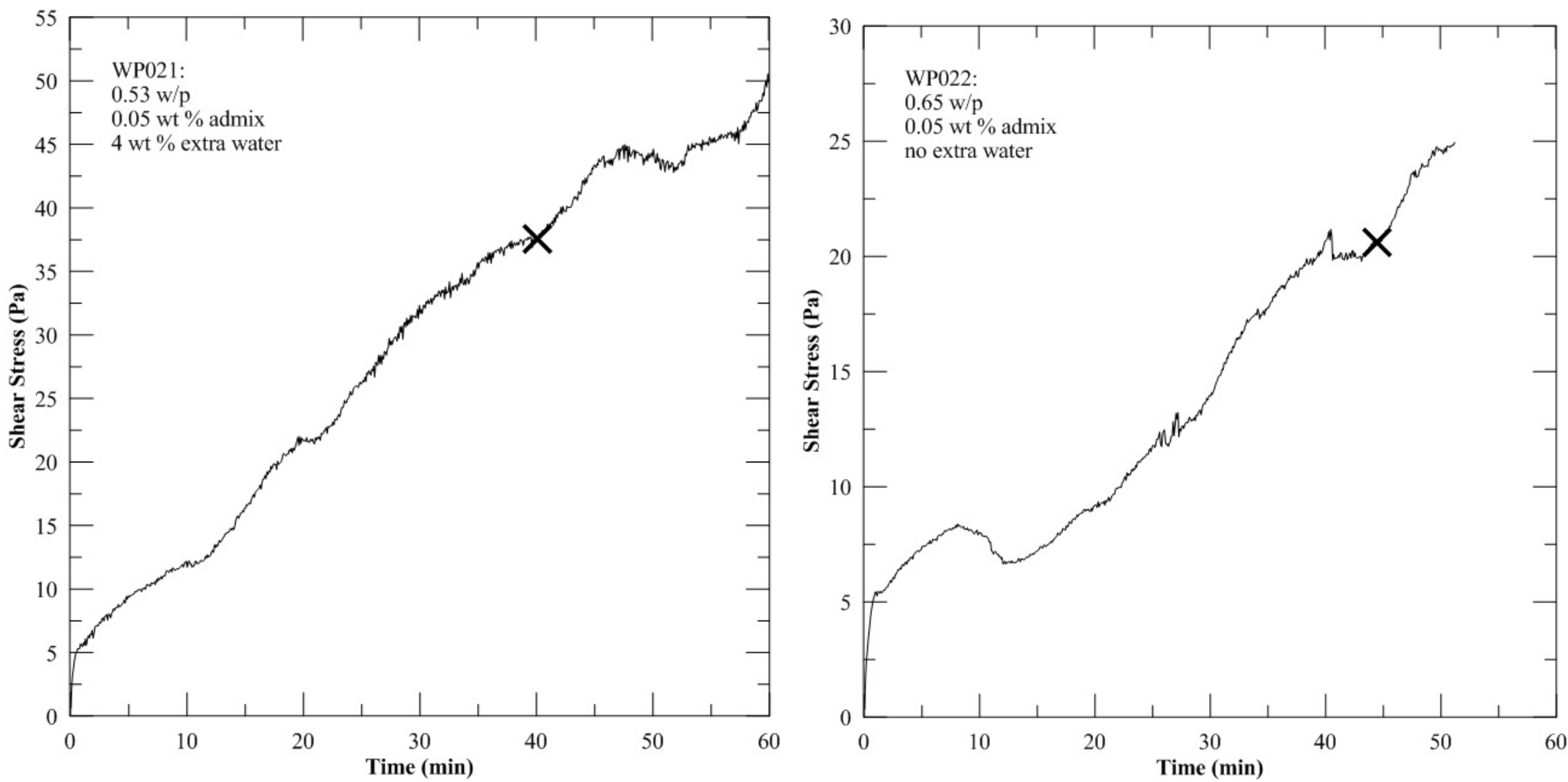

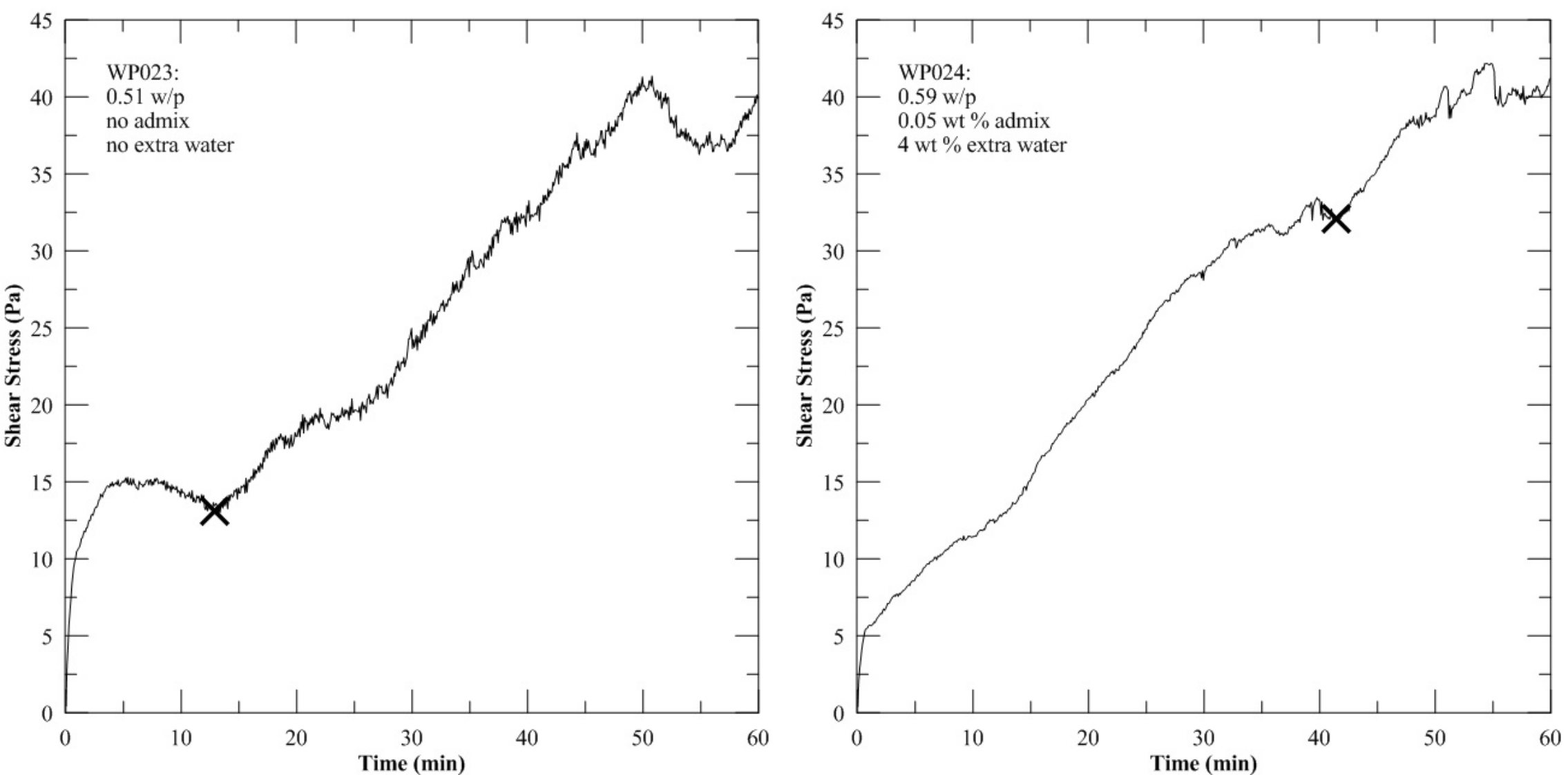


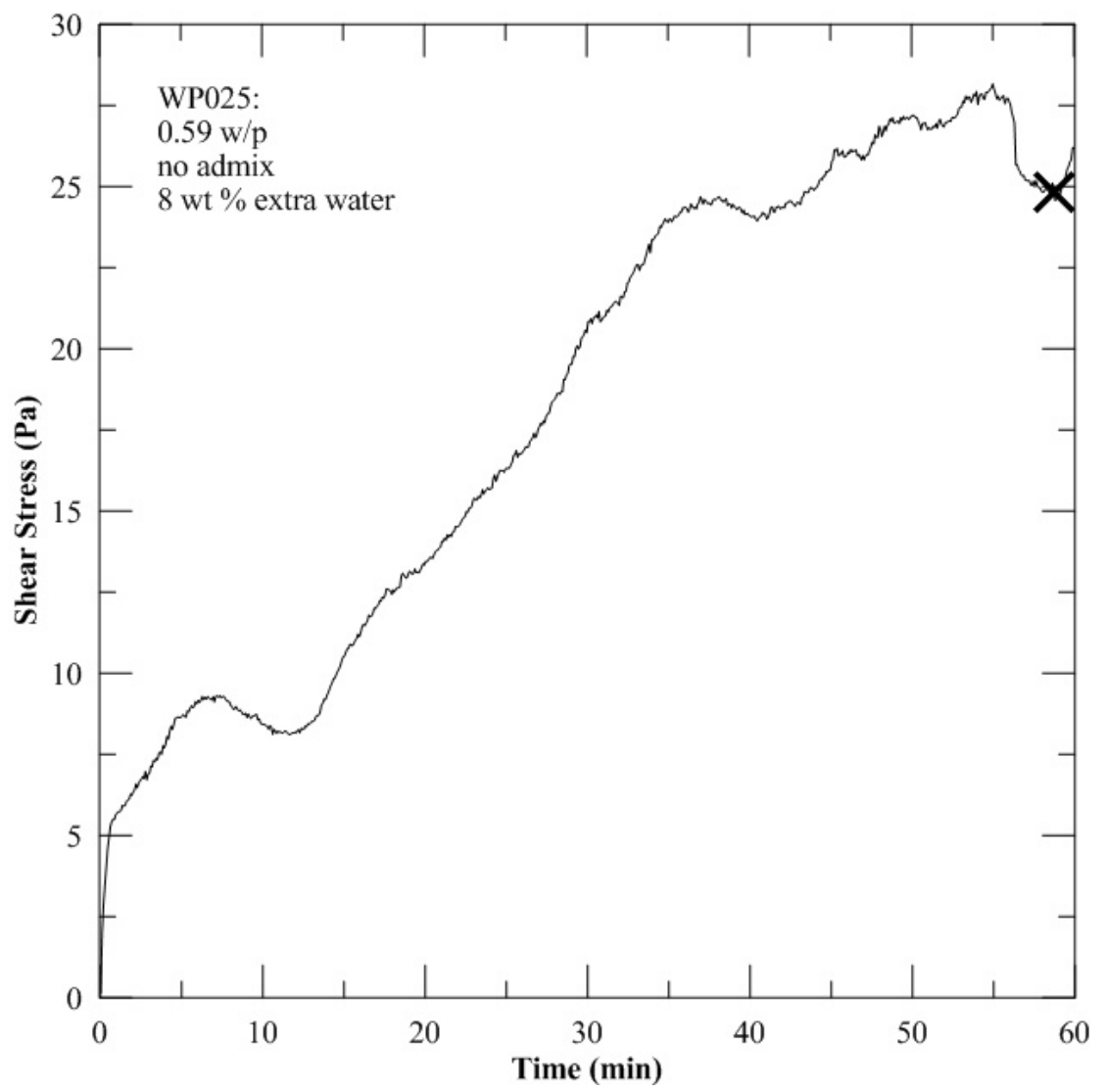


SRNL-STI-2012-00558

Revision 0

Appendix C. Inputs for Calculating Leachability Index 
Table C-1. Leachate pH

\begin{tabular}{|c|c|c|c|c|c|c|c||}
\hline $\begin{array}{c}\text { Saltstone } \\
\text { Bottle ID }\end{array}$ & \multicolumn{7}{|c|}{ Leachate Sample Elapsed Time } \\
\hline & $\mathbf{2 ~ h r}$ & $\mathbf{7} \mathbf{~ h r}$ & $\mathbf{2 4} \mathbf{~ h r}$ & $\mathbf{4 8} \mathbf{~ h r}$ & $\mathbf{7 2 ~ h r}$ & $\mathbf{9 6} \mathbf{~ r}$ & $\mathbf{1 2 0} \mathbf{~ r}$ \\
\hline \hline WP001-A & 9.66 & 9.9 & 10.25 & 10.56 & 10.34 & 10.36 & 10.2 \\
\hline WP001-B & 9.48 & 9.91 & 10.29 & 10.65 & 10.25 & 10.4 & 10.24 \\
\hline WP003-A & 9.49 & 9.8 & 10.33 & 10.63 & 10.26 & 10.34 & 10.17 \\
\hline WP003-B & 9.3 & 9.88 & 10.18 & 10.55 & 10.36 & 10.26 & 10.32 \\
\hline WP005-A & 10.11 & 10.22 & 10.69 & 10.95 & 10.72 & 10.73 & 10.68 \\
\hline WP005-B & 9.46 & 10.3 & 10.71 & 10.93 & 10.72 & 10.69 & 10.65 \\
\hline WP010-A & 9.32 & 9.83 & 10.41 & 10.48 & 10.25 & 10.42 & 10.23 \\
\hline WP010-B & 9.26 & 9.9 & 10.31 & 10.49 & 10.2 & 10.39 & 10.23 \\
\hline WP011-A & 9.98 & 9.86 & 10.56 & 10.66 & 10.64 & 10.54 & 10.47 \\
\hline WP011-B & 9.68 & 10.01 & 10.52 & 10.7 & 10.33 & 10.37 & 10.57 \\
\hline Blank-1 & 7.97 & 8.26 & 8.59 & 8.59 & 8.11 & 7.52 & 8.84 \\
\hline WP014-A & 9.62 & 10.25 & 10.57 & 10.51 & 10.49 & 10.63 & 10.64 \\
\hline WP014-B & 10.31 & 9.58 & 10.51 & 10.48 & 10.41 & 10.22 & 10.52 \\
\hline WP018-A & 10.58 & 10.12 & 10.86 & 10.87 & 10.69 & 10.63 & 10.82 \\
\hline WP018-B & 10.38 & 10.35 & 10.74 & 10.67 & 10.58 & 10.86 & 10.82 \\
\hline WP021-A & 10.4 & 10.37 & 10.6 & 10.52 & 10.5 & 10.52 & 10.59 \\
\hline WP021-B & 10.4 & 10.31 & 10.67 & 10.69 & 10.42 & 10.47 & 10.61 \\
\hline WP023-A & 10.3 & 10.17 & 10.64 & 10.71 & 10.39 & 10.54 & 10.72 \\
\hline WP023-B & 10.17 & 10.29 & 10.6 & 10.52 & 10.44 & 10.6 & 10.52 \\
\hline Blank-2 & 8.49 & 8.81 & 8.98 & 8.98 & 8.85 & 8.62 & 9 \\
\hline \hline
\end{tabular}


Table C-2. Leachate conductivities $[\mu \mathrm{S} / \mathrm{cm}]$

\begin{tabular}{|c|c|c|c|c|c|c|c||}
\hline \multirow{2}{*}{$\begin{array}{c}\text { Saltstone } \\
\text { Bottle ID }\end{array}$} & \multicolumn{7}{|c|}{ Leachate Sample Elapsed Time } \\
\cline { 2 - 9 } & $\mathbf{2} \mathbf{~ r}$ & $\mathbf{7} \mathbf{~ h r}$ & $\mathbf{2 4} \mathbf{~ h r}$ & $\mathbf{4 8} \mathbf{~ h r}$ & $\mathbf{7 2} \mathbf{~ h r}$ & $\mathbf{9 6} \mathbf{~ h r}$ & $\mathbf{1 2 0} \mathbf{~ h r}$ \\
\hline \hline 1-A & 179.6 & 353 & 693 & 763 & 498 & 392 & 385 \\
\hline 1-B & 143 & 337 & 721 & 878 & 458 & 460 & 401 \\
\hline 3-A & 123 & 272.1 & 748 & 865 & 486 & 404 & 374 \\
\hline 3-B & 93.1 & 315 & 557 & 754 & 559 & 356 & 491 \\
\hline 5-A & 542 & 608 & 1316 & 1367 & 907 & 717 & 674 \\
\hline 5-B & 199.1 & 800 & 1430 & 1346 & 942 & 568 & 696 \\
\hline 10-A & 137.5 & 325 & 787 & 580 & 445 & 436 & 334 \\
\hline 10-B & 114.1 & 357 & 641 & 616 & 403 & 390 & 330 \\
\hline 11-A & 574 & 535 & 1393 & 1115 & 963 & 736 & 632 \\
\hline 11-B & 231 & 502 & 1140 & 1118 & 683 & 481 & 580 \\
\hline Blank-1 & 1.04 & 1.1 & 1.14 & 1.26 & 1.21 & 1.21 & 1.12 \\
\hline 14-A & 63.2 & 327 & 693 & 632 & 409 & 393 & 431 \\
\hline 14-B & 350 & 71.1 & 584 & 572 & 438 & 149.1 & 332 \\
\hline 18-A & 773 & 302 & 1337 & 1370 & 919 & 402 & 640 \\
\hline 18-B & 360 & 413 & 910 & 711 & 617 & 602 & 583 \\
\hline 21-A & 568 & 626 & 883 & 736 & 632 & 372 & 457 \\
\hline 21-B & 545 & 534 & 1057 & 984 & 504 & 396 & 492 \\
\hline 23-A & 436 & 424 & 957 & 1014 & 528 & 433 & 639 \\
\hline 23-B & 329 & 488 & 949 & 758 & 647 & 519 & 461 \\
\hline Blank-2 & 1.1 & 1.09 & 1.22 & 1.22 & 1.22 & 1.13 & 0.99 \\
\hline
\end{tabular}


Table C-3. Leachate sodium concentrations [mg/L]

\begin{tabular}{|c|c|c|c|c|c|c|c|}
\hline \multirow{2}{*}{$\begin{array}{l}\text { Saltstone } \\
\text { Bottle ID }\end{array}$} & \multicolumn{7}{|c|}{ Leachate Sample Elapsed Time } \\
\hline & $2 \mathrm{hr}$ & $7 \mathrm{hr}$ & $24 \mathrm{hr}$ & $48 \mathrm{hr}$ & $72 \mathrm{hr}$ & $96 \mathrm{hr}$ & $120 \mathrm{hr}$ \\
\hline $1-\mathrm{A}$ & 48.3 & 38.3 & 85.5 & 90.5 & 65.8 & 49.6 & 53.7 \\
\hline $1-\mathrm{B}$ & 40.1 & 31.1 & 76.3 & 81.8 & 60.7 & 48.3 & 40.2 \\
\hline 3-A & 30.1 & 31.4 & 93.6 & 94.7 & 55.5 & 56.0 & 49.4 \\
\hline 3-B & 33.6 & 31.5 & 69.6 & 73.3 & 47.8 & 43.8 & 41.0 \\
\hline 5-A & 67.6 & 85.4 & 198 & 140 & 103 & 87.6 & 64.7 \\
\hline $5-\mathrm{B}$ & 76.6 & 87.1 & 178 & 151 & 130 & 83.3 & 75.7 \\
\hline $10-A$ & 34.2 & 40.0 & 85.7 & 85.8 & 58.7 & 55.9 & 39.3 \\
\hline $10-B$ & 42.8 & 35.6 & 68.5 & 72.6 & 56.2 & 50.9 & 47.7 \\
\hline $11-\mathrm{A}$ & 60.6 & 70.6 & 161 & 146 & 115 & 75.6 & 73.6 \\
\hline $11-B$ & 62.2 & 65.6 & 144 & 134 & 102 & 77.6 & 41.5 \\
\hline Blank-1 & $<1.00$ & $<1.00$ & $<1.00$ & $<1.00$ & $<1.00$ & $<1.00$ & $<1.00$ \\
\hline $14-\mathrm{A}$ & 44.0 & 34.0 & 81.7 & 72.4 & 62.3 & 52.0 & 46.0 \\
\hline $14-B$ & 26.1 & 34.9 & 61.4 & 60.0 & 45.5 & 48.9 & 33.5 \\
\hline 18-A & 73.0 & 123 & 193 & 182 & 132.0 & 118 & 79.0 \\
\hline 18-B & 30.2 & 42.0 & 96.9 & 111 & 66.7 & 60.1 & 54.8 \\
\hline $21-A$ & 52.0 & 58.1 & 124 & 105 & 196 & 83.4 & 58.4 \\
\hline 21-B & 83.9 & 60.0 & 155 & 132 & 120 & 107 & 84.1 \\
\hline 23-A & 51.2 & 61.5 & 141 & 156 & 110 & 104 & 67.9 \\
\hline 23-B & 40.5 & 38.9 & 121 & 95.8 & 71.7 & 73.6 & 59.5 \\
\hline Blank-2 & $<1.00$ & $<1.00$ & 1.25 & $<1.00$ & $<1.00$ & $<1.00$ & $<1.00$ \\
\hline
\end{tabular}


Table C-4. Leachate $\mathrm{NO}_{2}^{-}$Concentrations [mg/L]

\begin{tabular}{|c|c|c|c|c|c|c|c|}
\hline \multirow{2}{*}{$\begin{array}{l}\text { Saltstone } \\
\text { Bottle ID }\end{array}$} & \multicolumn{7}{|c|}{ Leachate Sample Elapsed Time } \\
\hline & 2 hr & $7 \mathrm{hr}$ & $24 \mathrm{hr}$ & $48 \mathrm{hr}$ & $72 \mathrm{hr}$ & $96 \mathrm{hr}$ & $120 \mathrm{hr}$ \\
\hline 1-A & 43.5 & 51.8 & 27.9 & 11.1 & 21.0 & 16.2 & 16.4 \\
\hline $1-\mathrm{B}$ & 40.6 & 57.4 & 26.0 & 25.9 & 19.3 & 16.1 & 13.0 \\
\hline 3-A & 24.9 & 22.8 & 10.4 & 22.4 & 17.3 & 17.9 & 16.2 \\
\hline $3-B$ & 31.4 & 30.0 & 10.2 & $<10.00$ & 15.3 & 14.5 & 12.7 \\
\hline $5-A$ & 27.4 & 25.8 & $<10.00$ & 12.7 & 27.8 & 24.3 & 17.9 \\
\hline $5-B$ & 29.4 & 27.9 & 12.4 & 15.3 & 36.2 & 23.2 & 19.1 \\
\hline $10-\mathrm{A}$ & 47.6 & 22.5 & $<10.00$ & 27.8 & 17.2 & 17.0 & 11.6 \\
\hline $10-\mathrm{B}$ & 53.3 & 24.4 & $<10.00$ & 23.6 & 16.8 & 15.7 & 13.8 \\
\hline 11-A & 21.9 & 11.8 & 20.8 & 48.3 & 3.38 & 23.5 & 23.6 \\
\hline $11-\mathrm{B}$ & 27.1 & 13.6 & 21.0 & 43.4 & 3.07 & 24.2 & 22.9 \\
\hline Blank-1 & $<10.00$ & $<10.00$ & $<10.00$ & $<10.00$ & $<10.00$ & $<10.00$ & $<10.00$ \\
\hline 14-A & 13.2 & 10.7 & 27.6 & 25.0 & 19.8 & 16.7 & 14.1 \\
\hline $14-B$ & $<10.00$ & 11.0 & 22.0 & 19.5 & 14.5 & 15.7 & 10.4 \\
\hline 18-A & 24.5 & 40.6 & 60.5 & 56.7 & 39.1 & 36.8 & 24.0 \\
\hline 18-B & $<10.00$ & 13.2 & 29.6 & 33.2 & 21.4 & 17.9 & 16.0 \\
\hline $21-A$ & 17.5 & 19.0 & 43.2 & 39.1 & 28.8 & 25.8 & 18.6 \\
\hline 21-B & 27.0 & 20.4 & 50.3 & 42.9 & 39.3 & 34.3 & 26.9 \\
\hline $23-A$ & 16.6 & 21.9 & 48.7 & 51.2 & 35.3 & 34.0 & 20.6 \\
\hline 23-B & 13.2 & 13.0 & 43.3 & 34.0 & 24.7 & 23.0 & 20.2 \\
\hline Blank-2 & $<10.00$ & $<10.00$ & $<10.00$ & $<10.00$ & $<10.00$ & $<10.00$ & $<10.00$ \\
\hline
\end{tabular}


SRNL-STI-2012-00558

Revision 0

Table C-5. Leachate $\mathrm{NO}_{3}{ }^{-}$concentrations $[\mathrm{mg} / \mathrm{L}]$

\begin{tabular}{|c|c|c|c|c|c|c|c||}
\hline \multirow{2}{*}{$\begin{array}{c}\text { Saltstone } \\
\text { Bottle ID }\end{array}$} & \multicolumn{7}{|c|}{ Leachate Sample Elapsed Time } \\
\cline { 2 - 8 } & $\mathbf{2 ~ h r}$ & $\mathbf{7 ~ h r}$ & $\mathbf{2 4} \mathbf{~ h r}$ & $\mathbf{4 8} \mathbf{~ h r}$ & $\mathbf{7 2} \mathbf{~ h r}$ & $\mathbf{9 6} \mathbf{~ r r}$ & $\mathbf{1 2 0} \mathbf{~ h r}$ \\
\hline \hline 1-A & 297 & 344 & 182 & 65.5 & 129 & 99.9 & 96.5 \\
\hline 1-B & 273 & 384 & 174 & 165 & 118 & 97.8 & 75.8 \\
\hline 3-A & 149 & 136 & 62.7 & 144 & 109 & 113 & 102 \\
\hline 3-B & 190 & 178 & 62.4 & 63.4 & 95.0 & 86.6 & 75.7 \\
\hline 5-A & 162 & 152 & 57.1 & 54.8 & 192 & 168 & 125 \\
\hline 5-B & 176 & 167 & 72.2 & 74.8 & 248 & 160 & 132 \\
\hline 10-A & 287 & 127 & $<10.00$ & 173 & 110 & 110 & 71.4 \\
\hline 10-B & 323 & 141 & 11.4 & 145 & 108 & 99.5 & 84.9 \\
\hline 11-A & 134 & 68.8 & 127 & 301 & 219 & 153 & 157 \\
\hline 11-B & 165 & 81.1 & 123 & 270 & 197 & 156 & 150 \\
\hline Blank-1 & $<10.00$ & $<10.00$ & $<10.00$ & $<10.00$ & $<10.00$ & $<10.00$ & $<10.00$ \\
\hline 14-A & 78.2 & 64.0 & 158 & 143 & 114 & 99.1 & 85.6 \\
\hline 14-B & 43.4 & 62.1 & 130 & 112 & 84.0 & 94.9 & 60.2 \\
\hline 18-A & 145 & 258 & 384 & 362 & 250 & 237 & 153 \\
\hline 18-B & 58.5 & 81.3 & 189 & 214 & 138 & 116 & 103 \\
\hline 21-A & 111 & 113 & 265 & 241 & 175 & 163 & 113 \\
\hline 21-B & 163 & 119 & 308 & 265 & 250 & 217 & 169 \\
\hline 23-A & 98.0 & 132 & 293 & 315 & 219 & 209 & 126 \\
\hline 23-B & 76.0 & 75.7 & 252 & 205 & 145 & 141 & 122 \\
\hline Blank-2 & $<10.00$ & 10.2 & $<10.00$ & $<10.00$ & $<10.00$ & $<10.00$ & $<10.00$ \\
\hline
\end{tabular}

To calculate the amount of species in the Saltstone sample initially $\left(\mathrm{A}_{0}\right)$, the composition of the various components going into the Saltstone sample had to be identified. The salt solution was mixed with the pre-mix, an admixture, and some additional water for each Saltstone sample as shown in Table C-6. The wt\% of the species $\mathrm{Cr}, \mathrm{Na}, \mathrm{NO}_{3}{ }^{-}$, and $\mathrm{NO}_{2}{ }^{-}$in the salt solution are shown in Table C-7. For the pre-mix components (Cement, Slag, Fly Ash,) the weight percent of the $\mathrm{Cr}, \mathrm{Na}, \mathrm{NO}_{3}{ }^{-}$, and $\mathrm{NO}_{2}{ }^{-}$species are shown in Table C-8. For the Saltstone samples in this study the pre-mix components were mixed as $10 \mathrm{wt} \%$ cement, $45 \mathrm{wt} \%$ Slag, and $45 \mathrm{wt} \%$ fly ash. Using the mass and component concentration data for the salt solution, pre-mix, admixture, and additional water, the wt\% of the species $\mathrm{Cr}, \mathrm{Na}, \mathrm{NO}_{3}{ }^{-}$, and $\mathrm{NO}_{2}{ }^{-}$in the final Saltstone mix were calculated as shown in Table C-9. The calculations showed that the amount of $\mathrm{Cr}(\mathrm{III})$ from the $\mathrm{Cr}_{2} \mathrm{O}_{3}$ in the pre-mix was about equal to the amount of $\mathrm{Cr}(\mathrm{VI})$ from $\mathrm{Na}_{2} \mathrm{CrO}_{4}$ as the $\mathrm{Cr}$ * column in Table C-9 illustrates. Normally the amount of $\mathrm{Cr}(\mathrm{III})$ from the $\mathrm{Cr}_{2} \mathrm{O}_{3}$ in pre-mix is treated as insoluble or not leachable once in the Saltstone final form. To be conservative, the total amount of $\mathrm{Cr}$ in the initial Saltstone sample $\left(\mathrm{A}_{0}\right)$ is calculated using the concentration of $\mathrm{Cr}$ with and without the pre-mix contribution. Note that the $\mathrm{NO}_{3}{ }^{-}$and $\mathrm{NO}_{2}{ }^{-}$concentrations for the pre-mix components are zero and the $\mathrm{Cr}$, $\mathrm{Na}, \mathrm{NO}_{3}^{-}$, and $\mathrm{NO}_{2}{ }^{-}$concentrations in the admix are considered zero. 
Table C-6. Saltstone Component Masses [g]

\begin{tabular}{|c|c|c|c|c|}
\hline $\begin{array}{c}\text { Saltstone } \\
\text { Sample ID }\end{array}$ & $\begin{array}{c}\text { Salt } \\
\text { Solution }\end{array}$ & $\begin{array}{c}\text { Pre- } \\
\text { mix }\end{array}$ & Admixture & $\begin{array}{c}\text { Additional } \\
\text { Water }\end{array}$ \\
\hline WP001 & 2490 & 3009.5 & 0 & 0 \\
\hline WP003 & 305.6 & 325 & 0.1 & 0 \\
\hline WP005 & 255.4 & 325 & 0.1 & 45.5 \\
\hline WP010 & 2281 & 2815 & 2.25 & 402.6 \\
\hline WP011 & 1540.4 & 1924.4 & 0.58 & 134.7 \\
\hline WP014 & 2394.5 & 3100 & 0.93 & 0 \\
\hline WP018 & 2783.4 & 2715 & 0.811 & 0 \\
\hline WP021 & 1476 & 1983.8 & 1.59 & 138.6 \\
\hline WP023 & 1502 & 2096.1 & 0.63 & 0 \\
\hline
\end{tabular}

Table C-7. Salt Solution Component Concentrations [wt\%]

\begin{tabular}{|c|c|c|c|}
\hline $\mathbf{C r}$ & $\mathbf{N a}$ & $\mathbf{N O}_{3}{ }^{-}$ & $\mathbf{N O}_{2}{ }^{-}$ \\
\hline 0.024 & 9.93 & 11.75 & 2.03 \\
\hline
\end{tabular}

Table C-8. Pre-mix Component Concentrations [wt\%]

\begin{tabular}{|c|c|c|c|c|}
\hline $\begin{array}{c}\text { Pre-mix } \\
\text { Component }\end{array}$ & $\mathbf{C r}$ & $\mathbf{N a}$ & $\mathbf{N O}_{\mathbf{3}}^{-}$ & $\mathbf{N O}_{\mathbf{2}}^{-}$ \\
\hline Cement & 0.019 & 0.183 & 0 & 0 \\
\hline Slag & 0.016 & 0.176 & 0 & 0 \\
\hline Fly Ash & 0.027 & 0.349 & 0 & 0 \\
\hline
\end{tabular}

Table C-9. Saltstone Mix Component Concentrations [wt\%]

\begin{tabular}{||c|c|c|c|c|c||}
\hline $\begin{array}{c}\text { Saltstone } \\
\text { Sample ID }\end{array}$ & $\mathbf{C r}$ & $\mathbf{C r} \boldsymbol{*}^{*}$ & $\mathbf{N a}$ & $\mathbf{N O}_{3}{ }^{-}$ & $\mathbf{N O}_{2}{ }^{-}$ \\
\hline WP001 & 0.0109 & 0.0227 & 4.6363 & 5.3190 & 0.9198 \\
\hline WP003 & 0.0117 & 0.0228 & 4.9438 & 5.6922 & 0.9843 \\
\hline WP005 & 0.0098 & 0.0211 & 4.1844 & 4.7929 & 0.8288 \\
\hline WP010 & 0.0100 & 0.0210 & 4.2488 & 4.8713 & 0.8424 \\
\hline WP011 & 0.0103 & 0.0219 & 4.3859 & 5.0266 & 0.8692 \\
\hline WP014 & 0.0105 & 0.0227 & 4.4713 & 5.1188 & 0.8852 \\
\hline WP018 & 0.0122 & 0.0228 & 5.1529 & 5.9460 & 1.0282 \\
\hline WP021 & 0.0099 & 0.0218 & 4.2125 & 4.8165 & 0.8329 \\
\hline WP023 & 0.0101 & 0.0226 & 4.2937 & 4.9031 & 0.8479 \\
\hline
\end{tabular}

*Includes $\mathrm{Cr}(\mathrm{III})$ or $\mathrm{Cr}_{2} \mathrm{O}_{3}$ in pre-mix along with salt solution $\mathrm{Cr}(\mathrm{VI})$ or $\mathrm{Na}_{2} \mathrm{CrO}_{4}$

Now that the Saltstone mix concentrations in Table C-9 are defined, the masses of the initial cut Saltstone Samples are needed as shown in Table C-10. Note that there were multiple vials of each Saltstone mix that were cured and only the masses of the vials leached are shown in Table C-10.

Using the concentrations of Table C-9 and the masses in Table C-10, the initial amount of the various species in the Saltstone Samples $\left(\mathrm{A}_{0}\right)$ can be calculated. Excluding the $\mathrm{Cr}$ in the pre-mix, the initial 
amounts of $\mathrm{Cr}$ in the Saltstone Samples are shown in Table C-11. Including the $\mathrm{Cr}$ in the pre-mix, the initial amounts of $\mathrm{Cr}$ in the Saltstone Samples are shown in Table C-12. The initial amounts of $\mathrm{Na}, \mathrm{NO}_{3}{ }^{-}$, and $\mathrm{NO}_{2}{ }^{-}$in the cut Saltstone Samples are shown in Table C-13, Table C-14 and Table C-15, respectively.

Table C-10. Initial masses of cut saltstone samples

\begin{tabular}{|c|c|c|c|c|}
\hline Saltstone Sample ID & Vial 1 & Vial 2 & Vial 3 & Vial 4 \\
\hline WP001 & & 86.8277 & 87.318 & \\
\hline WP003 & 84.5618 & & & 84.1677 \\
\hline WP005 & 81.5039 & & & 79.4580 \\
\hline WP010 & 82.8712 & & 82.4526 & \\
\hline WP011 & & & 82.8827 & 84.2573 \\
\hline WP014 & 86.2742 & & & 87.4940 \\
\hline WP018 & & & 82.4400 & 84.5803 \\
\hline WP021 & 86.9141 & & 86.8276 & \\
\hline WP023 & & 87.3019 & 88.3543 & \\
\hline
\end{tabular}

Table C-11. Cut Saltstone Sample Initial Cr Masses [g]

\begin{tabular}{|c|c|c|c|c|}
\hline & & & & \\
Saltstone Sample ID & Vial 1 & Vial 2 & Vial 3 & Vial 4 \\
\hline WP001 & & 0.009 & 0.010 & \\
\hline WP003 & 0.010 & & & 0.010 \\
\hline WP005 & 0.008 & & & 0.008 \\
\hline WP010 & 0.008 & & 0.008 & \\
\hline WP011 & & & 0.009 & 0.009 \\
\hline WP014 & 0.009 & & & 0.009 \\
\hline WP018 & & & 0.010 & 0.010 \\
\hline WP021 & 0.009 & & 0.009 & \\
\hline WP023 & & 0.009 & 0.009 & \\
\hline
\end{tabular}

Table C-12. Cut Saltstone Sample Initial Cr* Masses [g]

\begin{tabular}{|c|c|c|c|c|}
\hline & & & & \\
Saltstone Sample ID & Vial 1 & Vial 2 & Vial 3 & Vial 4 \\
\hline WP001 & & 0.020 & 0.020 & \\
\hline WP003 & 0.019 & & & 0.019 \\
\hline WP005 & 0.017 & & & 0.017 \\
\hline WP010 & 0.017 & & 0.017 & \\
\hline WP011 & & & 0.018 & 0.018 \\
\hline WP014 & 0.020 & & & 0.020 \\
\hline WP018 & & & 0.019 & 0.019 \\
\hline WP021 & 0.019 & & 0.019 & \\
\hline WP023 & & 0.020 & 0.020 & \\
\hline
\end{tabular}

*Includes $\mathrm{Cr}(\mathrm{III})$ or $\mathrm{Cr}_{2} \mathrm{O}_{3}$ in pre-mix along with salt solution $\mathrm{Cr}(\mathrm{VI})$ or $\mathrm{Na}_{2} \mathrm{CrO}_{4}$ 
Table C-13. Cut Saltstone Sample Initial Na Masses [g]

\begin{tabular}{|c|c|c|c|c|}
\hline Saltstone Sample ID & Vial 1 & Vial 2 & Vial 3 & Vial 4 \\
\hline WP001 & & 4.026 & 4.048 & \\
\hline WP003 & 4.181 & & & 4.161 \\
\hline WP005 & 3.410 & & & 3.325 \\
\hline WP010 & 3.521 & & 3.503 & \\
\hline WP011 & & & 3.635 & 3.695 \\
\hline WP014 & 3.858 & & & 3.912 \\
\hline WP018 & & & 4.248 & 4.358 \\
\hline WP021 & 3.661 & & 3.658 & \\
\hline WP023 & & 3.748 & 3.794 & \\
\hline
\end{tabular}

Table C-14. Cut Saltstone Sample Initial $\mathrm{NO}_{3}{ }^{-}$Masses [g]

\begin{tabular}{|c|c|c|c|c|}
\hline Saltstone Sample ID & Vial 1 & Vial 2 & Vial 3 & Vial 4 \\
\hline WP001 & & 4.618 & 4.644 & \\
\hline WP003 & 4.813 & & & 4.791 \\
\hline WP005 & 3.906 & & & 3.808 \\
\hline WP010 & 4.037 & & 4.017 & \\
\hline WP011 & & & 4.166 & 4.235 \\
\hline WP014 & 4.416 & & & 4.479 \\
\hline WP018 & & & 4.902 & 5.029 \\
\hline WP021 & 4.186 & & 4.182 & \\
\hline WP023 & & 4.281 & 4.332 & \\
\hline
\end{tabular}

Table C-15. Cut Saltstone Sample Initial $\mathrm{NO}_{2}{ }^{-}$Masses [g]

\begin{tabular}{|c|c|c|c|c|}
\hline Saltstone Sample ID & Vial 1 & Vial 2 & Vial 3 & Vial 4 \\
\hline WP001 & & 0.799 & 0.803 & \\
\hline WP003 & 0.832 & & & 0.828 \\
\hline WP005 & 0.676 & & & 0.659 \\
\hline WP010 & 0.698 & & 0.695 & \\
\hline WP011 & & & 0.720 & 0.732 \\
\hline WP014 & 0.764 & & & 0.774 \\
\hline WP018 & & & 0.848 & 0.870 \\
\hline WP021 & 0.724 & & 0.723 & \\
\hline WP023 & & 0.740 & 0.749 & \\
\hline
\end{tabular}

The volume to surface area ratios for the cut Saltstone samples are shown in Table C-16. Note that since the volumes are in $\mathrm{cm}^{3}$ and the surface areas are in $\mathrm{cm}^{2}$ then the ratios are in $\mathrm{cm}$. 
Table C-16. Cut Saltstone Sample Volume to Surface Area Ratios (V/S) [cm]

\begin{tabular}{|c|c|c|c|c|}
\hline Saltstone Sample ID & Vial 1 & Vial 2 & Vial 3 & Vial 4 \\
\hline WP001 & & 1.292 & 1.289 & \\
\hline WP003 & 1.295 & & & 1.289 \\
\hline WP005 & 1.320 & & & 1.287 \\
\hline WP010 & 1.292 & & 1.286 & \\
\hline WP011 & & & 1.285 & 1.286 \\
\hline WP014 & 1.283 & & & 1.284 \\
\hline WP018 & & & 1.286 & 1.280 \\
\hline WP021 & 1.297 & & 1.292 & \\
\hline WP023 & & 1.278 & 1.293 & \\
\hline
\end{tabular}

Since the mass or volume of leachant used and the concentration of each species in the leachate are known for each Saltstone sample at each time interval, the mass of each species in the leachant at each time interval can be calculated. The time intervals in the ANSI/ANS 16.1 standard are shown in Table C-17. Table C-18 shows the leachate masses for $\mathrm{Cr}$ if the $\mathrm{Cr}$ in the pre-mix is excluded for each time interval and Table $\mathrm{C}-19$ shows the leachate masses for $\mathrm{Cr}$ if the $\mathrm{Cr}$ in the pre-mix is included.

Table C-20, Table C-21, and Table C-22show the leachate masses for $\mathrm{Na}, \mathrm{NO}_{3}{ }^{-}$, and $\mathrm{NO}_{2}{ }^{-}$for each time interval, respectively.

Table C-17. Leaching Time Parameters [s]

\begin{tabular}{|c|c|c|c|}
\hline Time Interval n & $\mathbf{t}_{\mathbf{n}}$ & $\mathbf{( \Delta \mathbf { t } ) _ { \mathbf { n } }}$ & $\mathbf{T}$ \\
\hline 1 & 7,200 & 7,200 & 1,800 \\
\hline 2 & 18,000 & 25,200 & 14,835 \\
\hline 3 & 86,400 & 61,200 & 51,231 \\
\hline 4 & 172,800 & 86,400 & 125,894 \\
\hline 5 & 259,200 & 86,400 & 213,818 \\
\hline 6 & 345,600 & 86,400 & 300,849 \\
\hline 7 & 432,000 & 86,400 & 387,596 \\
\hline
\end{tabular}


Table C-18. Leachate Masses $\left(a_{n}\right)$ for $\mathrm{Cr}$ [g]

\begin{tabular}{|c|c|c|c|c|c|}
\hline Time Interval n & Saltstone Sample ID & Vial 1 & Vial 2 & Vial 3 & Vial 4 \\
\hline \multirow{9}{*}{1} & WP001 & & $<7.87 \mathrm{E}-06$ & $<7.88 \mathrm{E}-06$ & \\
\hline & WP003 & $<7.90 \mathrm{E}-06$ & & & $<7.81 \mathrm{E}-06$ \\
\hline & WP005 & $<8.17 \mathrm{E}-06$ & & & $<7.78 \mathrm{E}-06$ \\
\hline & WP010 & $<7.84 \mathrm{E}-06$ & & $<7.76 \mathrm{E}-06$ & \\
\hline & WP011 & & & $<7.75 \mathrm{E}-06$ & $<7.77 \mathrm{E}-06$ \\
\hline & WP014 & $<7.76 \mathrm{E}-06$ & & & $<7.76 \mathrm{E}-06$ \\
\hline & WP018 & & & $<7.78 \mathrm{E}-06$ & $<7.68 \mathrm{E}-06$ \\
\hline & WP021 & $<7.94 \mathrm{E}-06$ & & $<7.90 \mathrm{E}-06$ & \\
\hline & WP023 & & $<7.66 \mathrm{E}-06$ & $<7.81 \mathrm{E}-06$ & \\
\hline \multirow{9}{*}{2} & WP001 & & $<7.87 \mathrm{E}-06$ & $<7.88 \mathrm{E}-06$ & \\
\hline & WP003 & $<7.90 \mathrm{E}-06$ & & & $<7.81 \mathrm{E}-06$ \\
\hline & WP005 & $<8.17 \mathrm{E}-06$ & & & $<7.78 \mathrm{E}-06$ \\
\hline & WP010 & $<7.84 \mathrm{E}-06$ & & $<7.76 \mathrm{E}-06$ & \\
\hline & WP011 & & & $<7.75 \mathrm{E}-06$ & $<7.77 \mathrm{E}-06$ \\
\hline & WP014 & $<7.76 \mathrm{E}-06$ & & & $<7.76 \mathrm{E}-06$ \\
\hline & WP018 & & & $<7.78 \mathrm{E}-06$ & $<7.68 \mathrm{E}-06$ \\
\hline & WP021 & $<7.94 \mathrm{E}-06$ & & $<7.90 \mathrm{E}-06$ & \\
\hline & WP023 & & $<7.66 \mathrm{E}-06$ & $<7.81 \mathrm{E}-06$ & \\
\hline \multirow{9}{*}{3} & WP001 & & $<7.87 \mathrm{E}-06$ & $<7.88 \mathrm{E}-06$ & \\
\hline & WP003 & $<7.90 \mathrm{E}-06$ & & & $<7.81 \mathrm{E}-06$ \\
\hline & WP005 & $<8.17 \mathrm{E}-06$ & & & $<7.78 \mathrm{E}-06$ \\
\hline & WP010 & $<7.84 \mathrm{E}-06$ & & $<7.76 \mathrm{E}-06$ & \\
\hline & WP011 & & & $<7.75 \mathrm{E}-06$ & $<7.77 \mathrm{E}-06$ \\
\hline & WP014 & $<7.76 \mathrm{E}-06$ & & & $<7.76 \mathrm{E}-06$ \\
\hline & WP018 & & & $<7.78 \mathrm{E}-06$ & $<7.68 \mathrm{E}-06$ \\
\hline & WP021 & $<7.94 \mathrm{E}-06$ & & $<7.90 \mathrm{E}-06$ & \\
\hline & WP023 & & $<7.66 \mathrm{E}-06$ & $<7.81 \mathrm{E}-06$ & \\
\hline \multirow{9}{*}{4} & WP001 & & $<7.87 \mathrm{E}-06$ & $<7.88 \mathrm{E}-06$ & \\
\hline & WP003 & $<7.90 \mathrm{E}-06$ & & & $<7.81 \mathrm{E}-06$ \\
\hline & WP005 & $<8.17 \mathrm{E}-06$ & & & $<7.78 \mathrm{E}-06$ \\
\hline & WP010 & $<7.84 \mathrm{E}-06$ & & $<7.76 \mathrm{E}-06$ & \\
\hline & WP011 & & & $<7.75 \mathrm{E}-06$ & $<7.77 \mathrm{E}-06$ \\
\hline & WP014 & $<7.76 \mathrm{E}-06$ & & & $<7.76 \mathrm{E}-06$ \\
\hline & WP018 & & & $<7.78 \mathrm{E}-06$ & $<7.68 \mathrm{E}-06$ \\
\hline & WP021 & $<7.94 \mathrm{E}-06$ & & $<7.90 \mathrm{E}-06$ & \\
\hline & WP023 & & $<7.66 \mathrm{E}-06$ & $<7.81 \mathrm{E}-06$ & \\
\hline \multirow{9}{*}{5} & WP001 & & $<7.87 \mathrm{E}-06$ & $<7.88 \mathrm{E}-06$ & \\
\hline & WP003 & $<7.90 \mathrm{E}-06$ & & & $<7.81 \mathrm{E}-06$ \\
\hline & WP005 & $<8.17 \mathrm{E}-06$ & & & $<7.78 \mathrm{E}-06$ \\
\hline & WP010 & $<7.84 \mathrm{E}-06$ & & $<7.76 \mathrm{E}-06$ & \\
\hline & WP011 & & & $<7.75 \mathrm{E}-06$ & $<7.77 \mathrm{E}-06$ \\
\hline & WP014 & $<7.76 \mathrm{E}-06$ & & & $<7.76 \mathrm{E}-06$ \\
\hline & WP018 & & & $<7.78 \mathrm{E}-06$ & $<7.68 \mathrm{E}-06$ \\
\hline & WP021 & $<7.94 \mathrm{E}-06$ & & $<7.90 \mathrm{E}-06$ & \\
\hline & WP023 & & $<7.66 \mathrm{E}-06$ & $<7.81 \mathrm{E}-06$ & \\
\hline
\end{tabular}


Table C-18. Leachate Masses $\left(a_{n}\right)$ for $\mathrm{Cr}$ [g]

\begin{tabular}{|c|c|c|c|c|c|}
\hline Time Interval n & Saltstone Sample ID & Vial 1 & Vial 2 & Vial 3 & Vial 4 \\
\hline \multirow{9}{*}{6} & WP001 & & $<7.87 \mathrm{E}-06$ & $<7.88 \mathrm{E}-06$ & \\
\hline & WP003 & $<7.90 \mathrm{E}-06$ & & & $<7.81 \mathrm{E}-06$ \\
\hline & WP005 & $<8.17 \mathrm{E}-06$ & & & $<7.78 \mathrm{E}-06$ \\
\hline & WP010 & $<7.84 \mathrm{E}-06$ & & $<7.76 \mathrm{E}-06$ & \\
\hline & WP011 & & & $<7.75 \mathrm{E}-06$ & $<7.77 \mathrm{E}-06$ \\
\hline & WP014 & $<7.76 \mathrm{E}-06$ & & & $<7.76 \mathrm{E}-06$ \\
\hline & WP018 & & & $<7.78 \mathrm{E}-06$ & $<7.68 \mathrm{E}-06$ \\
\hline & WP021 & $<7.94 \mathrm{E}-06$ & & $<7.90 \mathrm{E}-06$ & \\
\hline & WP023 & & $<7.66 \mathrm{E}-06$ & $<7.81 \mathrm{E}-06$ & \\
\hline \multirow{9}{*}{7} & WP001 & & $<7.87 \mathrm{E}-06$ & $<7.88 \mathrm{E}-06$ & \\
\hline & WP003 & $<7.90 \mathrm{E}-06$ & & & $<7.81 \mathrm{E}-06$ \\
\hline & WP005 & $<8.17 \mathrm{E}-06$ & & & $<7.78 \mathrm{E}-06$ \\
\hline & WP010 & $<7.84 \mathrm{E}-06$ & & $<7.76 \mathrm{E}-06$ & \\
\hline & WP011 & & & $<7.75 \mathrm{E}-06$ & $<7.77 \mathrm{E}-06$ \\
\hline & WP014 & $<7.76 \mathrm{E}-06$ & & & $<7.76 \mathrm{E}-06$ \\
\hline & WP018 & & & $<7.78 \mathrm{E}-06$ & $<7.68 \mathrm{E}-06$ \\
\hline & WP021 & $<7.94 \mathrm{E}-06$ & & $<7.90 \mathrm{E}-06$ & \\
\hline & WP023 & & $<7.66 \mathrm{E}-06$ & $<7.81 \mathrm{E}-06$ & \\
\hline
\end{tabular}


Table C-19. Leachate Masses $\left(a_{n}\right)$ for $\mathrm{Cr}^{*}$ [g]

\begin{tabular}{|c|c|c|c|c|c|}
\hline Time Interval n & Saltstone Sample ID & Vial 1 & Vial 2 & Vial 3 & Vial 4 \\
\hline \multirow{9}{*}{1} & WP001 & & $<7.87 \mathrm{E}-06$ & $<7.88 \mathrm{E}-06$ & \\
\hline & WP003 & $<7.90 \mathrm{E}-06$ & & & $<7.81 \mathrm{E}-06$ \\
\hline & WP005 & $<8.17 \mathrm{E}-06$ & & & $<7.78 \mathrm{E}-06$ \\
\hline & WP010 & $<7.84 \mathrm{E}-06$ & & $<7.76 \mathrm{E}-06$ & \\
\hline & WP011 & & & $<7.75 \mathrm{E}-06$ & $<7.77 \mathrm{E}-06$ \\
\hline & WP014 & $<7.76 \mathrm{E}-06$ & & & $<7.76 \mathrm{E}-06$ \\
\hline & WP018 & & & $<7.78 \mathrm{E}-06$ & $<7.68 \mathrm{E}-06$ \\
\hline & WP021 & $<7.94 \mathrm{E}-06$ & & $<7.90 \mathrm{E}-06$ & \\
\hline & WP023 & & $<7.66 \mathrm{E}-06$ & $<7.81 \mathrm{E}-06$ & \\
\hline \multirow{9}{*}{2} & WP001 & & $<7.87 \mathrm{E}-06$ & $<7.88 \mathrm{E}-06$ & \\
\hline & WP003 & $<7.90 \mathrm{E}-06$ & & & $<7.81 \mathrm{E}-06$ \\
\hline & WP005 & $<8.17 \mathrm{E}-06$ & & & $<7.78 \mathrm{E}-06$ \\
\hline & WP010 & $<7.84 \mathrm{E}-06$ & & $<7.76 \mathrm{E}-06$ & \\
\hline & WP011 & & & $<7.75 \mathrm{E}-06$ & $<7.77 \mathrm{E}-06$ \\
\hline & WP014 & $<7.76 \mathrm{E}-06$ & & & $<7.76 \mathrm{E}-06$ \\
\hline & WP018 & & & $<7.78 \mathrm{E}-06$ & $<7.68 \mathrm{E}-06$ \\
\hline & WP021 & $<7.94 \mathrm{E}-06$ & & $<7.90 \mathrm{E}-06$ & \\
\hline & WP023 & & $<7.66 \mathrm{E}-06$ & $<7.81 \mathrm{E}-06$ & \\
\hline \multirow{9}{*}{3} & WP001 & & $<7.87 \mathrm{E}-06$ & $<7.88 \mathrm{E}-06$ & \\
\hline & WP003 & $<7.90 \mathrm{E}-06$ & & & $<7.81 \mathrm{E}-06$ \\
\hline & WP005 & $<8.17 \mathrm{E}-06$ & & & $<7.78 \mathrm{E}-06$ \\
\hline & WP010 & $<7.84 \mathrm{E}-06$ & & $<7.76 \mathrm{E}-06$ & \\
\hline & WP011 & & & $<7.75 \mathrm{E}-06$ & $<7.77 \mathrm{E}-06$ \\
\hline & WP014 & $<7.76 \mathrm{E}-06$ & & & $<7.76 \mathrm{E}-06$ \\
\hline & WP018 & & & $<7.78 \mathrm{E}-06$ & $<7.68 \mathrm{E}-06$ \\
\hline & WP021 & $<7.94 \mathrm{E}-06$ & & $<7.90$ E-06 & \\
\hline & WP023 & & $<7.66 \mathrm{E}-06$ & $<7.81 \mathrm{E}-06$ & \\
\hline \multirow{9}{*}{4} & WP001 & & $<$ <.87E-06 & $<7.88 \mathrm{E}-06$ & \\
\hline & WP003 & $<7.90 \mathrm{E}-06$ & & & $<7.81 \mathrm{E}-06$ \\
\hline & WP005 & $<8.17 \mathrm{E}-06$ & & & $<7.78 \mathrm{E}-06$ \\
\hline & WP010 & $<7.84 \mathrm{E}-06$ & & $<7.76 \mathrm{E}-06$ & \\
\hline & WP011 & & & $<7.75 \mathrm{E}-06$ & $<7.77 \mathrm{E}-06$ \\
\hline & WP014 & $<7.76 \mathrm{E}-06$ & & & $<7.76 \mathrm{E}-06$ \\
\hline & WP018 & & & $<7.78 \mathrm{E}-06$ & $<7.68 \mathrm{E}-06$ \\
\hline & WP021 & $<7.94 \mathrm{E}-06$ & & $<7.90 \mathrm{E}-06$ & \\
\hline & WP023 & & $<7.66 \mathrm{E}-06$ & $<7.81 \mathrm{E}-06$ & \\
\hline \multirow{9}{*}{5} & WP001 & & $<$ > 7.87E-06 & $<7.88 \mathrm{E}-06$ & \\
\hline & WP003 & $<7.90 \mathrm{E}-06$ & & & $<7.81 \mathrm{E}-06$ \\
\hline & WP005 & $<8.17 \mathrm{E}-06$ & & & $<7.78 \mathrm{E}-06$ \\
\hline & WP010 & $<7.84 \mathrm{E}-06$ & & $<7.76 \mathrm{E}-06$ & \\
\hline & WP011 & & & $<7.75 \mathrm{E}-06$ & $<7.77 \mathrm{E}-06$ \\
\hline & WP014 & $<7.76 \mathrm{E}-06$ & & & $<7.76 \mathrm{E}-06$ \\
\hline & WP018 & & & $<7.78 \mathrm{E}-06$ & $<7.68 \mathrm{E}-06$ \\
\hline & WP021 & $<7.94 \mathrm{E}-06$ & & $<7.90 \mathrm{E}-06$ & \\
\hline & WP023 & & $<7.66 \mathrm{E}-06$ & $<7.81 \mathrm{E}-06$ & \\
\hline
\end{tabular}


Table C-19. Leachate Masses $\left(\mathrm{a}_{\mathrm{n}}\right)$ for $\mathrm{Cr}$ [g]

\begin{tabular}{|c|c|c|c|c|c|}
\hline Time Interval n & Saltstone Sample ID & Vial 1 & Vial 2 & Vial 3 & Vial 4 \\
\hline \multirow{9}{*}{6} & WP001 & & $<7.87 \mathrm{E}-06$ & $<7.88 \mathrm{E}-06$ & \\
\hline & WP003 & $<7.90 \mathrm{E}-06$ & & & $<7.81 \mathrm{E}-06$ \\
\hline & WP005 & $<8.17 \mathrm{E}-06$ & & & $<7.78 \mathrm{E}-06$ \\
\hline & WP010 & $<7.84 \mathrm{E}-06$ & & $<7.76 \mathrm{E}-06$ & \\
\hline & WP011 & & & $<7.75 \mathrm{E}-06$ & $<7.77 \mathrm{E}-06$ \\
\hline & WP014 & $<7.76 \mathrm{E}-06$ & & & $<7.76 \mathrm{E}-06$ \\
\hline & WP018 & & & $<7.78 \mathrm{E}-06$ & $<7.68 \mathrm{E}-06$ \\
\hline & WP021 & $<7.94 \mathrm{E}-06$ & & $<7.90 \mathrm{E}-06$ & \\
\hline & WP023 & & $<7.66 \mathrm{E}-06$ & $<7.81 \mathrm{E}-06$ & \\
\hline \multirow{9}{*}{7} & WP001 & & $<7.87 \mathrm{E}-06$ & $<7.88 \mathrm{E}-06$ & \\
\hline & WP003 & $<7.90 \mathrm{E}-06$ & & & $<7.81 \mathrm{E}-06$ \\
\hline & WP005 & $<8.17 \mathrm{E}-06$ & & & $<7.78 \mathrm{E}-06$ \\
\hline & WP010 & $<7.84 \mathrm{E}-06$ & & $<7.76 \mathrm{E}-06$ & \\
\hline & WP011 & & & $<7.75 \mathrm{E}-06$ & $<7.77 \mathrm{E}-06$ \\
\hline & WP014 & $<7.76 \mathrm{E}-06$ & & & $<7.76 \mathrm{E}-06$ \\
\hline & WP018 & & & $<7.78 \mathrm{E}-06$ & $<7.68 \mathrm{E}-06$ \\
\hline & WP021 & $<7.94 \mathrm{E}-06$ & & $<7.90 \mathrm{E}-06$ & \\
\hline & WP023 & & $<7.66 \mathrm{E}-06$ & $<7.81 \mathrm{E}-06$ & \\
\hline
\end{tabular}

*Includes $\mathrm{Cr}(\mathrm{III})$ or $\mathrm{Cr}_{2} \mathrm{O}_{3}$ in pre-mix along with salt solution $\mathrm{Cr}(\mathrm{VI})$ or $\mathrm{Na}_{2} \mathrm{CrO}_{4}$ 
Table C-20. Leachate Masses ( $\left.a_{n}\right)$ for Na [g]

\begin{tabular}{|c|c|c|c|c|c|}
\hline Time Interval n & Saltstone Sample ID & Vial 1 & Vial 2 & Vial 3 & Vial 4 \\
\hline \multirow{9}{*}{1} & WP001 & & 0.0380 & 0.0316 & \\
\hline & WP003 & 0.0238 & & & 0.0262 \\
\hline & WP005 & 0.0552 & & & 0.0596 \\
\hline & WP010 & 0.0268 & & 0.0332 & \\
\hline & WP011 & & & 0.0470 & 0.0483 \\
\hline & WP014 & 0.0341 & & & 0.0203 \\
\hline & WP018 & & & 0.0568 & 0.0232 \\
\hline & WP021 & 0.0413 & & 0.0663 & \\
\hline & WP023 & & 0.0392 & 0.0316 & \\
\hline \multirow{9}{*}{2} & WP001 & & 0.0302 & 0.0245 & \\
\hline & WP003 & 0.0248 & & & 0.0246 \\
\hline & WP005 & 0.0698 & & & 0.0678 \\
\hline & WP010 & 0.0314 & & 0.0276 & \\
\hline & WP011 & & & 0.0547 & 0.0510 \\
\hline & WP014 & 0.0264 & & & 0.0271 \\
\hline & WP018 & & & 0.0957 & 0.0323 \\
\hline & WP021 & 0.0461 & & 0.0474 & \\
\hline & WP023 & & 0.0471 & 0.0304 & \\
\hline \multirow{9}{*}{3} & WP001 & & 0.0673 & 0.0601 & \\
\hline & WP003 & 0.0739 & & & 0.0543 \\
\hline & WP005 & 0.1618 & & & 0.1385 \\
\hline & WP010 & 0.0672 & & 0.0532 & \\
\hline & WP011 & & & 0.1248 & 0.1119 \\
\hline & WP014 & 0.0634 & & & 0.0476 \\
\hline & WP018 & & & 0.1499 & 0.0744 \\
\hline & WP021 & 0.0987 & & 0.1227 & \\
\hline & WP023 & & 0.1078 & 0.0942 & \\
\hline \multirow{9}{*}{4} & WP001 & & 0.0713 & 0.0644 & \\
\hline & WP003 & 0.0748 & & & 0.0572 \\
\hline & WP005 & 0.1144 & & & 0.1175 \\
\hline & WP010 & 0.0673 & & 0.0564 & \\
\hline & WP011 & & & 0.1132 & 0.1041 \\
\hline & WP014 & 0.0562 & & & 0.0466 \\
\hline & WP018 & & & 0.1416 & 0.0852 \\
\hline & WP021 & 0.0834 & & 0.1043 & \\
\hline & WP023 & & 0.1195 & 0.0749 & \\
\hline \multirow{8}{*}{5} & WP001 & & 0.0518 & 0.0478 & \\
\hline & WP003 & 0.0438 & & & 0.0373 \\
\hline & WP005 & 0.0842 & & & 0.1012 \\
\hline & WP010 & 0.0460 & & 0.0436 & \\
\hline & WP011 & & & 0.0892 & 0.0793 \\
\hline & WP014 & 0.0483 & & & 0.0353 \\
\hline & WP018 & & & 0.1027 & 0.0512 \\
\hline & WP021 & 0.1557 & & 0.0948 & \\
\hline
\end{tabular}


Table C-20. Leachate Masses ( $\left.a_{n}\right)$ for Na [g]

\begin{tabular}{|c|c|c|c|c|c|}
\hline \multirow{3}{*}{ Time Interval n } & Saltstone Sample ID & Vial 1 & Vial 2 & Vial 3 & Vial 4 \\
\hline & & & & & \\
\hline \multirow{5}{*}{6} & WP023 & & 0.0843 & 0.0560 & \\
\cline { 2 - 6 } & WP001 & & 0.0391 & 0.0380 & \\
\cline { 2 - 6 } & WP003 & 0.0442 & & & 0.0342 \\
\cline { 2 - 6 } & WP005 & 0.0716 & & & 0.0648 \\
\cline { 2 - 6 } & WP010 & 0.0438 & & 0.0395 & \\
\cline { 2 - 6 } & WP011 & & & 0.0586 & 0.0603 \\
\cline { 2 - 6 } & WP014 & 0.0403 & & & 0.0379 \\
\cline { 2 - 6 } & WP021 & & & 0.0918 & 0.0461 \\
\hline \multirow{5}{*}{7} & WP023 & & 0.0794 & 0.0575 & \\
\cline { 2 - 6 } & WP01 & & 0.0423 & 0.0317 & \\
\cline { 2 - 6 } & WP03 & 0.0390 & & & 0.0320 \\
\cline { 2 - 6 } & WP005 & 0.0529 & & & 0.0589 \\
\cline { 2 - 6 } & WP010 & 0.0308 & & 0.0370 & \\
\cline { 2 - 6 } & WP011 & & & 0.0571 & 0.0322 \\
\cline { 2 - 6 } & WP014 & 0.0357 & & & 0.0260 \\
\cline { 2 - 6 } & WP018 & & & 0.0615 & 0.0421 \\
\cline { 2 - 6 } & WP021 & 0.0464 & & 0.0664 & \\
\hline WP023 & & 0.0520 & 0.0465 & \\
\hline
\end{tabular}


Table C-21. Leachate Masses $\left(a_{n}\right)$ for $\mathrm{NO}_{3}{ }^{-}[g]$

\begin{tabular}{|c|c|c|c|c|c|}
\hline Time Interval n & Saltstone Sample ID & Vial 1 & Vial 2 & Vial 3 & Vial 4 \\
\hline \multirow{9}{*}{1} & WP001 & & 0.2339 & 0.2150 & \\
\hline & WP003 & 0.1176 & & & 0.1484 \\
\hline & WP005 & 0.1324 & & & 0.1370 \\
\hline & WP010 & 0.2251 & & 0.2507 & \\
\hline & WP011 & & & 0.1039 & 0.1282 \\
\hline & WP014 & 0.0607 & & & 0.0337 \\
\hline & WP018 & & & 0.1128 & 0.0449 \\
\hline & WP021 & 0.0882 & & 0.1287 & \\
\hline & WP023 & & 0.0751 & 0.0594 & \\
\hline \multirow{9}{*}{2} & WP001 & & 0.2709 & 0.3025 & \\
\hline & WP003 & 0.1074 & & & 0.1390 \\
\hline & WP005 & 0.1242 & & & 0.1300 \\
\hline & WP010 & 0.0996 & & 0.1095 & \\
\hline & WP011 & & & 0.0533 & 0.0630 \\
\hline & WP014 & 0.0496 & & & 0.0482 \\
\hline & WP018 & & & 0.2007 & 0.0624 \\
\hline & WP021 & 0.0897 & & 0.0940 & \\
\hline & WP023 & & 0.1010 & 0.0592 & \\
\hline \multirow{9}{*}{3} & WP001 & & 0.1433 & 0.1371 & \\
\hline & WP003 & 0.0495 & & & 0.0487 \\
\hline & WP005 & 0.0467 & & & 0.0562 \\
\hline & WP010 & $<0.0078$ & & 0.0088 & \\
\hline & WP011 & & & 0.0985 & 0.0956 \\
\hline & WP014 & 0.1225 & & & 0.1007 \\
\hline & WP018 & & & 0.2986 & 0.1450 \\
\hline & WP021 & 0.2101 & & 0.2432 & \\
\hline & WP023 & & 0.2246 & 0.1968 & \\
\hline \multirow{9}{*}{4} & WP001 & & 0.0516 & 0.1300 & \\
\hline & WP003 & 0.1137 & & & 0.0495 \\
\hline & WP005 & 0.0448 & & & 0.0582 \\
\hline & WP010 & 0.1357 & & 0.1126 & \\
\hline & WP011 & & & 0.2334 & 0.2098 \\
\hline & WP014 & 0.1109 & & & 0.0867 \\
\hline & WP018 & & & 0.2819 & 0.1642 \\
\hline & WP021 & 0.1915 & & 0.2094 & \\
\hline & WP023 & & 0.2414 & 0.1602 & \\
\hline \multirow{9}{*}{5} & WP001 & & 0.1016 & 0.0929 & \\
\hline & WP003 & 0.0861 & & & 0.0742 \\
\hline & WP005 & 0.1569 & & & 0.1930 \\
\hline & WP010 & 0.0863 & & 0.0838 & \\
\hline & WP011 & & & 0.1698 & 0.1531 \\
\hline & WP014 & 0.0885 & & & 0.0652 \\
\hline & WP018 & & & 0.1942 & 0.1059 \\
\hline & WP021 & 0.1389 & & 0.1971 & \\
\hline & WP023 & & 0.1677 & 0.1130 & \\
\hline
\end{tabular}


Table C-21. Leachate Masses $\left(a_{n}\right)$ for $\mathrm{NO}_{3}{ }^{-}$[g]

\begin{tabular}{|c|c|c|c|c|c|}
\hline \multirow{4}{*}{ Time Interval n } & Saltstone Sample ID & Vial 1 & Vial 2 & Vial 3 & Vial 4 \\
\hline \multirow{5}{*}{6} & WP001 & & 0.0787 & 0.0770 & \\
\cline { 2 - 6 } & WP003 & 0.0892 & & & 0.0676 \\
\cline { 2 - 6 } & WP005 & 0.1373 & & & 0.1245 \\
\cline { 2 - 6 } & WP010 & 0.0863 & & 0.0772 & \\
\cline { 2 - 6 } & WP011 & & & 0.1186 & 0.1212 \\
\cline { 2 - 6 } & WP014 & 0.0769 & & & 0.0736 \\
\cline { 2 - 6 } & WP018 & & & 0.1847 & 0.0892 \\
\cline { 2 - 6 } & WP021 & 0.1296 & & 0.1716 & \\
\hline \multirow{5}{*}{7} & WP023 & & 0.1601 & 0.1102 & \\
\cline { 2 - 6 } & WP001 & & 0.0760 & 0.0597 & \\
\cline { 2 - 6 } & WP03 & 0.0805 & & & 0.0591 \\
\cline { 2 - 6 } & WP05 & 0.1022 & & & 0.1027 \\
\cline { 2 - 6 } & WP010 & 0.0560 & & 0.0659 & \\
\cline { 2 - 6 } & WP011 & & & 0.1217 & 0.1165 \\
\cline { 2 - 6 } & WP014 & 0.0664 & & & 0.0467 \\
\cline { 2 - 6 } & WP018 & & & 0.1190 & 0.0791 \\
\cline { 2 - 6 } & WP021 & 0.0897 & & 0.1335 & \\
\cline { 2 - 6 } & WP023 & & 0.0965 & 0.0953 & \\
\hline
\end{tabular}


Table C-22. Leachate Masses $\left(a_{n}\right)$ for $\mathrm{NO}_{2}^{-}[g]$

\begin{tabular}{|c|c|c|c|c|c|}
\hline Time Interval n & Saltstone Sample ID & Vial 1 & Vial 2 & Vial 3 & Vial 4 \\
\hline \multirow{9}{*}{1} & WP001 & & 0.0343 & 0.0320 & \\
\hline & WP003 & 0.0197 & & & 0.0245 \\
\hline & WP005 & 0.0224 & & & 0.0229 \\
\hline & WP010 & 0.0373 & & 0.0414 & \\
\hline & WP011 & & & 0.0170 & 0.0211 \\
\hline & WP014 & 0.0102 & & & $<0.0078$ \\
\hline & WP018 & & & 0.0191 & $<0.0077$ \\
\hline & WP021 & 0.0139 & & 0.0213 & \\
\hline & WP023 & & 0.0127 & 0.0103 & \\
\hline \multirow{9}{*}{2} & WP001 & & 0.0408 & 0.0452 & \\
\hline & WP003 & 0.0180 & & & 0.0234 \\
\hline & WP005 & 0.0211 & & & 0.0217 \\
\hline & WP010 & 0.0176 & & 0.0189 & \\
\hline & WP011 & & & 0.0091 & 0.0106 \\
\hline & WP014 & 0.0083 & & & 0.0085 \\
\hline & WP018 & & & 0.0316 & 0.0101 \\
\hline & WP021 & 0.0151 & & 0.0161 & \\
\hline & WP023 & & 0.0168 & 0.0102 & \\
\hline \multirow{9}{*}{3} & WP001 & & 0.0220 & 0.0205 & \\
\hline & WP003 & 0.0082 & & & 0.0080 \\
\hline & WP005 & $<0.0082$ & & & 0.0097 \\
\hline & WP010 & $<0.0078$ & & $<0.0078$ & \\
\hline & WP011 & & & 0.0161 & 0.0163 \\
\hline & WP014 & 0.0214 & & & 0.0170 \\
\hline & WP018 & & & 0.0471 & 0.0227 \\
\hline & WP021 & 0.0343 & & 0.0397 & \\
\hline & WP023 & & 0.0373 & 0.0338 & \\
\hline \multirow{9}{*}{4} & WP001 & & 0.0087 & 0.0204 & \\
\hline & WP003 & 0.0177 & & & $<0.0078$ \\
\hline & WP005 & 0.0104 & & & 0.0119 \\
\hline & WP010 & 0.0218 & & 0.0183 & \\
\hline & WP011 & & & 0.0374 & 0.0337 \\
\hline & WP014 & 0.0194 & & & 0.0151 \\
\hline & WP018 & & & 0.0441 & 0.0255 \\
\hline & WP021 & 0.0311 & & 0.0339 & \\
\hline & WP023 & & 0.0392 & 0.0265 & \\
\hline \multirow{9}{*}{5} & WP001 & & 0.0165 & 0.0152 & \\
\hline & WP003 & 0.0137 & & & 0.0119 \\
\hline & WP005 & 0.0227 & & & 0.0282 \\
\hline & WP010 & 0.0135 & & 0.0130 & \\
\hline & WP011 & & & 0.0026 & 0.0024 \\
\hline & WP014 & 0.0154 & & & 0.0113 \\
\hline & WP018 & & & 0.0304 & 0.0164 \\
\hline & WP021 & 0.0229 & & 0.0310 & \\
\hline & WP023 & & 0.0270 & 0.0193 & \\
\hline
\end{tabular}


Table C-22. Leachate Masses $\left(a_{n}\right)$ for $\mathrm{NO}_{2}^{-}[g]$

\begin{tabular}{|c|c|c|c|c|c|}
\hline Time Interval n & Saltstone Sample ID & Vial 1 & Vial 2 & Vial 3 & Vial 4 \\
\hline \multirow{9}{*}{6} & WP001 & & 0.0128 & 0.0127 & \\
\hline & WP003 & 0.0141 & & & 0.0113 \\
\hline & WP005 & 0.0199 & & & 0.0181 \\
\hline & WP010 & 0.0133 & & 0.0122 & \\
\hline & WP011 & & & 0.0182 & 0.0188 \\
\hline & WP014 & 0.0130 & & & 0.0122 \\
\hline & WP018 & & & 0.0287 & 0.0137 \\
\hline & WP021 & 0.0205 & & 0.0271 & \\
\hline & WP023 & & 0.0260 & 0.0180 & \\
\hline \multirow{9}{*}{7} & WP001 & & 0.0129 & 0.0102 & \\
\hline & WP003 & 0.0128 & & & 0.0099 \\
\hline & WP005 & 0.0146 & & & 0.0149 \\
\hline & WP010 & 0.0091 & & 0.0107 & \\
\hline & WP011 & & & 0.0183 & 0.0178 \\
\hline & WP014 & 0.0109 & & & 0.0081 \\
\hline & WP018 & & & 0.0187 & 0.0123 \\
\hline & WP021 & 0.0148 & & 0.0212 & \\
\hline & WP023 & & 0.0158 & 0.0158 & \\
\hline
\end{tabular}

Inserting the leachate masses at the various time intervals $\left(a_{n}\right)$ from Table C-18 through Table C-22, the initial species masses $\left(A_{0}\right)$ from Table $C-11$ through Table $C-15$, the time intervals $(\Delta t)_{n}$ and mean leaching times $(\mathrm{T})$ from Table C-17, and the volume to surface area ratios (V/S) from Table C-16 into Equation (3-1), the effective diffusivity of the leaching species for each time interval $\mathrm{n}$ can be calculated. Table C-23 shows the effective diffusivity for $\mathrm{Cr}$ if the $\mathrm{Cr}$ in the pre-mix is excluded for each time interval and Table $\mathrm{C}$-24 shows the effective diffusivity for $\mathrm{Cr}$ if the $\mathrm{Cr}$ in the pre-mix is included. Table C-25, Table C-26, and Table C-27 show the effective diffusivity for $\mathrm{Na}, \mathrm{NO}_{3}^{-}$, and $\mathrm{NO}_{2}^{-}$, respectively. 
Table C-23. Effective Diffusivity $\left(D_{e, n}^{N a}\right)$ for $\mathrm{Cr}\left[\mathrm{cm}^{2} / \mathrm{s}\right]$

\begin{tabular}{|c|c|c|c|c|c|}
\hline Time Interval n & Saltstone Sample ID & Vial 1 & Vial 2 & Vial 3 & Vial 4 \\
\hline \multirow{9}{*}{1} & WP001 & & $<1.26 \mathrm{E}-10$ & $<1.24 \mathrm{E}-10$ & \\
\hline & WP003 & $<1.17 \mathrm{E}-10$ & & & $<1.14 \mathrm{E}-10$ \\
\hline & WP005 & $<1.97 \mathrm{E}-10$ & & & $<1.79 \mathrm{E}-10$ \\
\hline & WP010 & $<1.64 \mathrm{E}-10$ & & $<1.60 \mathrm{E}-10$ & \\
\hline & WP011 & & & $<1.48 \mathrm{E}-10$ & $<1.44 \mathrm{E}-10$ \\
\hline & WP014 & $<1.32 \mathrm{E}-10$ & & & $<1.29 \mathrm{E}-10$ \\
\hline & WP018 & & & $<1.08 \mathrm{E}-10$ & $<9.92 \mathrm{E}-11$ \\
\hline & WP021 & $<1.57 \mathrm{E}-10$ & & $<1.55 \mathrm{E}-10$ & \\
\hline & WP023 & & $<1.36 \mathrm{E}-10$ & $<1.41 \mathrm{E}-10$ & \\
\hline \multirow{9}{*}{2} & WP001 & & $<1.66 \mathrm{E}-10$ & $<1.63 \mathrm{E}-10$ & \\
\hline & WP003 & $<1.54 \mathrm{E}-10$ & & & $<1.50 \mathrm{E}-10$ \\
\hline & WP005 & $<2.60 \mathrm{E}-10$ & & & $<2.36 \mathrm{E}-10$ \\
\hline & WP010 & $<2.16 \mathrm{E}-10$ & & $<2.12 \mathrm{E}-10$ & \\
\hline & WP011 & & & $<1.95 \mathrm{E}-10$ & $<1.90 \mathrm{E}-10$ \\
\hline & WP014 & $<1.74 \mathrm{E}-10$ & & & $<1.70 \mathrm{E}-10$ \\
\hline & WP018 & & & $<1.43 \mathrm{E}-10$ & $<1.31 \mathrm{E}-10$ \\
\hline & WP021 & $<2.07 \mathrm{E}-10$ & & $<2.04 \mathrm{E}-10$ & \\
\hline & WP023 & & $<1.79 \mathrm{E}-10$ & $<1.86 \mathrm{E}-10$ & \\
\hline \multirow{9}{*}{3} & WP001 & & $<4.94 \mathrm{E}-11$ & $<4.87 \mathrm{E}-11$ & \\
\hline & WP003 & $<4.59 \mathrm{E}-11$ & & & $<4.49 \mathrm{E}-11$ \\
\hline & WP005 & $<7.77 \mathrm{E}-11$ & & & $<7.04 \mathrm{E}-11$ \\
\hline & WP010 & $<6.45 \mathrm{E}-11$ & & $<6.32 \mathrm{E}-11$ & \\
\hline & WP011 & & & $<5.82 \mathrm{E}-11$ & $<5.66 \mathrm{E}-11$ \\
\hline & WP014 & $<5.19 \mathrm{E}-11$ & & & $<5.06 \mathrm{E}-11$ \\
\hline & WP018 & & & $<4.26 \mathrm{E}-11$ & $<3.91 \mathrm{E}-11$ \\
\hline & WP021 & $<6.19 \mathrm{E}-11$ & & $<6.09 \mathrm{E}-11$ & \\
\hline & WP023 & & $<5.35 \mathrm{E}-11$ & $<5.56 \mathrm{E}-11$ & \\
\hline \multirow{9}{*}{4} & WP001 & & $<6.10 \mathrm{E}-11$ & $<6.00 \mathrm{E}-11$ & \\
\hline & WP003 & $<5.66 \mathrm{E}-11$ & & & $<5.54 \mathrm{E}-11$ \\
\hline & WP005 & $<9.58 \mathrm{E}-11$ & & & $<8.68 \mathrm{E}-11$ \\
\hline & WP010 & $<7.95 \mathrm{E}-11$ & & $<7.79 \mathrm{E}-11$ & \\
\hline & WP011 & & & $<7.18 \mathrm{E}-11$ & $<6.98 \mathrm{E}-11$ \\
\hline & WP014 & $<6.40 \mathrm{E}-11$ & & & $<6.24 \mathrm{E}-11$ \\
\hline & WP018 & & & $<5.25 \mathrm{E}-11$ & $<4.82 \mathrm{E}-11$ \\
\hline & WP021 & $<7.63 \mathrm{E}-11$ & & $<7.51 \mathrm{E}-11$ & \\
\hline & WP023 & & $<6.60 \mathrm{E}-11$ & $<6.85 \mathrm{E}-11$ & \\
\hline \multirow{9}{*}{5} & WP001 & & $<1.04 \mathrm{E}-10$ & $<1.02 \mathrm{E}-10$ & \\
\hline & WP003 & $<9.62 \mathrm{E}-11$ & & & $<9.40 \mathrm{E}-11$ \\
\hline & WP005 & $<1.63 \mathrm{E}-10$ & & & $<1.47 \mathrm{E}-10$ \\
\hline & WP010 & $<1.35 \mathrm{E}-10$ & & $<1.32 \mathrm{E}-10$ & \\
\hline & WP011 & & & $<1.22 \mathrm{E}-10$ & $<1.19 \mathrm{E}-10$ \\
\hline & WP014 & $<1.09 \mathrm{E}-10$ & & & $<1.06 \mathrm{E}-10$ \\
\hline & WP018 & & & $<8.91 \mathrm{E}-11$ & $<8.18 \mathrm{E}-11$ \\
\hline & WP021 & $<1.30 \mathrm{E}-10$ & & $<1.27 \mathrm{E}-10$ & \\
\hline & WP023 & & $<1.12 \mathrm{E}-10$ & $<1.16 \mathrm{E}-10$ & \\
\hline
\end{tabular}


Table C-23. Effective Diffusivity $\left(D_{e, n}^{N a}\right)$ for $\mathrm{Cr}\left[\mathrm{cm}^{2} / \mathrm{s}\right]$

\begin{tabular}{|c|c|c|c|c|c|}
\hline Time Interval n & Saltstone Sample ID & Vial 1 & Vial 2 & Vial 3 & Vial 4 \\
\hline \multirow{9}{*}{6} & WP001 & & $<1.46 \mathrm{E}-10$ & $<1.43 \mathrm{E}-10$ & \\
\hline & WP003 & $<1.35 \mathrm{E}-10$ & & & $<1.32 \mathrm{E}-10$ \\
\hline & WP005 & $<2.29 \mathrm{E}-10$ & & & $<2.07 \mathrm{E}-10$ \\
\hline & WP010 & $<1.90 \mathrm{E}-10$ & & $<1.86 \mathrm{E}-10$ & \\
\hline & WP011 & & & $<1.72 \mathrm{E}-10$ & $<1.67 \mathrm{E}-10$ \\
\hline & WP014 & $<1.53 \mathrm{E}-10$ & & & $<1.49 \mathrm{E}-10$ \\
\hline & WP018 & & & $<1.25 \mathrm{E}-10$ & $<1.15 \mathrm{E}-10$ \\
\hline & WP021 & $<1.82 \mathrm{E}-10$ & & $<1.79 \mathrm{E}-10$ & \\
\hline & WP023 & & $<1.58 \mathrm{E}-10$ & $<1.64 \mathrm{E}-10$ & \\
\hline \multirow{9}{*}{7} & WP001 & & $<1.88 \mathrm{E}-10$ & $<1.85 \mathrm{E}-10$ & \\
\hline & WP003 & $<1.74 \mathrm{E}-10$ & & & $<1.70 \mathrm{E}-10$ \\
\hline & WP005 & $<2.95 \mathrm{E}-10$ & & & $<2.67 \mathrm{E}-10$ \\
\hline & WP010 & $<2.45 \mathrm{E}-10$ & & $<2.40 \mathrm{E}-10$ & \\
\hline & WP011 & & & $<2.21 \mathrm{E}-10$ & $<2.15 \mathrm{E}-10$ \\
\hline & WP014 & $<1.97 \mathrm{E}-10$ & & & $<1.92 \mathrm{E}-10$ \\
\hline & WP018 & & & $<1.62 \mathrm{E}-10$ & $<1.48 \mathrm{E}-10$ \\
\hline & WP021 & $<2.35 \mathrm{E}-10$ & & $<2.31 \mathrm{E}-10$ & \\
\hline & WP023 & & $<2.03 \mathrm{E}-10$ & $<2.11 \mathrm{E}-10$ & \\
\hline
\end{tabular}

*Includes $\mathrm{Cr}(\mathrm{III})$ or $\mathrm{Cr}_{2} \mathrm{O}_{3}$ in pre-mix along with salt solution $\mathrm{Cr}(\mathrm{VI})$ or $\mathrm{Na}_{2} \mathrm{CrO}_{4}$ 
Table C-24. Effective Diffusivity $\left(D_{e, n}^{N a}\right)$ for $\mathrm{Cr}^{*}\left[\mathrm{~cm}^{2} / \mathrm{s}\right]$

\begin{tabular}{|c|c|c|c|c|c|}
\hline Time Interval n & Saltstone Sample ID & Vial 1 & Vial 2 & Vial 3 & Vial 4 \\
\hline \multirow{9}{*}{1} & WP001 & & $<2.90 \mathrm{E}-11$ & $<2.85 \mathrm{E}-11$ & \\
\hline & WP003 & $<3.06 \mathrm{E}-11$ & & & $<2.99 \mathrm{E}-11$ \\
\hline & WP005 & $<4.31 \mathrm{E}-11$ & & & $<3.91 \mathrm{E}-11$ \\
\hline & WP010 & $<3.69 \mathrm{E}-11$ & & $<3.62 \mathrm{E}-11$ & \\
\hline & WP011 & & & $<3.30 \mathrm{E}-11$ & $<3.21 \mathrm{E}-11$ \\
\hline & WP014 & $<2.82 \mathrm{E}-11$ & & & $<2.75 \mathrm{E}-11$ \\
\hline & WP018 & & & $<3.08 \mathrm{E}-11$ & $<2.82 \mathrm{E}-11$ \\
\hline & WP021 & $<3.23 \mathrm{E}-11$ & & $<3.18 \mathrm{E}-11$ & \\
\hline & WP023 & & $<2.68 \mathrm{E}-11$ & $<2.79 \mathrm{E}-11$ & \\
\hline \multirow{9}{*}{2} & WP001 & & $<3.82 \mathrm{E}-11$ & $<3.76 \mathrm{E}-11$ & \\
\hline & WP003 & $<4.04 \mathrm{E}-11$ & & & $<3.95 \mathrm{E}-11$ \\
\hline & WP005 & $<5.69 \mathrm{E}-11$ & & & $<5.15 \mathrm{E}-11$ \\
\hline & WP010 & $<4.86 \mathrm{E}-11$ & & $<4.77 \mathrm{E}-11$ & \\
\hline & WP011 & & & $<4.35 \mathrm{E}-11$ & $<4.23 \mathrm{E}-11$ \\
\hline & WP014 & $<3.72 \mathrm{E}-11$ & & & $<3.63 \mathrm{E}-11$ \\
\hline & WP018 & & & $<4.06 \mathrm{E}-11$ & $<3.72 \mathrm{E}-11$ \\
\hline & WP021 & $<4.26 \mathrm{E}-11$ & & $<4.19 \mathrm{E}-11$ & \\
\hline & WP023 & & $<3.54 \mathrm{E}-11$ & $<3.67 \mathrm{E}-11$ & \\
\hline \multirow{9}{*}{3} & WP001 & & $<1.14 \mathrm{E}-11$ & $<1.12 \mathrm{E}-11$ & \\
\hline & WP003 & $<1.21 \mathrm{E}-11$ & & & $<1.18 \mathrm{E}-11$ \\
\hline & WP005 & $<1.70 \mathrm{E}-11$ & & & $<1.54 \mathrm{E}-11$ \\
\hline & WP010 & $<1.45 \mathrm{E}-11$ & & $<1.42 \mathrm{E}-11$ & \\
\hline & WP011 & & & $<1.30 \mathrm{E}-11$ & $<1.26 \mathrm{E}-11$ \\
\hline & WP014 & $<1.11 \mathrm{E}-11$ & & & $<1.09 \mathrm{E}-11$ \\
\hline & WP018 & & & $<1.21 \mathrm{E}-11$ & $<1.11 \mathrm{E}-11$ \\
\hline & WP021 & $<1.27 \mathrm{E}-11$ & & $<1.25 \mathrm{E}-11$ & \\
\hline & WP023 & & $<1.06 \mathrm{E}-11$ & $<1.10 \mathrm{E}-11$ & \\
\hline \multirow{9}{*}{4} & WP001 & & $<1.41 \mathrm{E}-11$ & $<1.39 \mathrm{E}-11$ & \\
\hline & WP003 & $<1.49 \mathrm{E}-11$ & & & $<1.45 \mathrm{E}-11$ \\
\hline & WP005 & $<2.09 \mathrm{E}-11$ & & & $<1.90 \mathrm{E}-11$ \\
\hline & WP010 & $<1.79 \mathrm{E}-11$ & & $<1.76 \mathrm{E}-11$ & \\
\hline & WP011 & & & $<1.60 \mathrm{E}-11$ & $<1.56 \mathrm{E}-11$ \\
\hline & WP014 & $<1.37 \mathrm{E}-11$ & & & $<1.34 \mathrm{E}-11$ \\
\hline & WP018 & & & $<1.49 \mathrm{E}-11$ & $<1.37 \mathrm{E}-11$ \\
\hline & WP021 & $<1.57 \mathrm{E}-11$ & & $<1.54 \mathrm{E}-11$ & \\
\hline & WP023 & & $<1.30 \mathrm{E}-11$ & $<1.35 \mathrm{E}-11$ & \\
\hline \multirow{8}{*}{5} & WP001 & & $<2.39 \mathrm{E}-11$ & $<2.35 \mathrm{E}-11$ & \\
\hline & WP003 & $<2.53 \mathrm{E}-11$ & & & $<2.47 \mathrm{E}-11$ \\
\hline & WP005 & $<3.56 \mathrm{E}-11$ & & & $<3.22 \mathrm{E}-11$ \\
\hline & WP010 & $<3.03 \mathrm{E}-11$ & & $<2.98 \mathrm{E}-11$ & \\
\hline & WP011 & & & $<2.72 \mathrm{E}-11$ & $<2.65 \mathrm{E}-11$ \\
\hline & WP014 & $<2.33 \mathrm{E}-11$ & & & $<2.27 \mathrm{E}-11$ \\
\hline & WP018 & & & $<2.54 \mathrm{E}-11$ & $<2.33 \mathrm{E}-11$ \\
\hline & WP021 & $<2.67 \mathrm{E}-11$ & & $<2.62 \mathrm{E}-11$ & \\
\hline
\end{tabular}


Table C-24. Effective Diffusivity $\left(D_{e, n}^{N a}\right)$ for $\mathrm{Cr}^{*}\left[\mathrm{~cm}^{2} / \mathrm{s}\right]$

\begin{tabular}{|c|c|c|c|c|c|}
\hline Time Interval n & Saltstone Sample ID & Vial 1 & Vial 2 & Vial 3 & Vial 4 \\
\hline & WP023 & & $<2.21 \mathrm{E}-11$ & $<2.30 \mathrm{E}-11$ & \\
\hline \multirow{9}{*}{6} & WP001 & & $<3.36 \mathrm{E}-11$ & $<3.31 \mathrm{E}-11$ & \\
\hline & WP003 & $<3.56 \mathrm{E}-11$ & & & $<3.48 \mathrm{E}-11$ \\
\hline & WP005 & $<5.01 \mathrm{E}-11$ & & & $<4.54 \mathrm{E}-11$ \\
\hline & WP010 & $<4.28 \mathrm{E}-11$ & & $<4.20 \mathrm{E}-11$ & \\
\hline & WP011 & & & $<3.83 \mathrm{E}-11$ & $<3.72 \mathrm{E}-11$ \\
\hline & WP014 & $<3.28 \mathrm{E}-11$ & & & $<3.20 \mathrm{E}-11$ \\
\hline & WP018 & & & $<3.57 \mathrm{E}-11$ & $<3.28 \mathrm{E}-11$ \\
\hline & WP021 & $<3.75 \mathrm{E}-11$ & & $<3.69 \mathrm{E}-11$ & \\
\hline & WP023 & & $<3.11 \mathrm{E}-11$ & $<3.23 \mathrm{E}-11$ & \\
\hline \multirow{9}{*}{7} & WP001 & & $<4.33 \mathrm{E}-11$ & $<4.27 \mathrm{E}-11$ & \\
\hline & WP003 & $<4.58 \mathrm{E}-11$ & & & $<4.48 \mathrm{E}-11$ \\
\hline & WP005 & $<6.45 \mathrm{E}-11$ & & & $<5.84 \mathrm{E}-11$ \\
\hline & WP010 & $<5.52 \mathrm{E}-11$ & & $<5.41 \mathrm{E}-11$ & \\
\hline & WP011 & & & $<4.93 \mathrm{E}-11$ & $<4.79 \mathrm{E}-11$ \\
\hline & WP014 & $<4.22 \mathrm{E}-11$ & & & $<4.12 \mathrm{E}-11$ \\
\hline & WP018 & & & $<4.60 \mathrm{E}-11$ & $<4.22 \mathrm{E}-11$ \\
\hline & WP021 & $<4.84 \mathrm{E}-11$ & & $<4.75 \mathrm{E}-11$ & \\
\hline & WP023 & & $<4.01 \mathrm{E}-11$ & $<4.17 \mathrm{E}-11$ & \\
\hline
\end{tabular}


Table C-25. Effective Diffusivity $\left(D_{e, n}^{N a}\right)$ for Na $\left[\mathrm{cm}^{2} / \mathrm{s}\right]$

\begin{tabular}{|c|c|c|c|c|c|}
\hline Time Interval n & Saltstone Sample ID & Vial 1 & Vial 2 & Vial 3 & Vial 4 \\
\hline \multirow{9}{*}{1} & WP001 & & 1.63E-08 & $1.10 \mathrm{E}-08$ & \\
\hline & WP003 & 5.91E-09 & & & 7.20E-09 \\
\hline & WP005 & 4.99E-08 & & & 5.81E-08 \\
\hline & WP010 & $1.06 \mathrm{E}-08$ & & $1.62 \mathrm{E}-08$ & \\
\hline & WP011 & & & 3.01E-08 & 3.08E-08 \\
\hline & WP014 & $1.41 \mathrm{E}-08$ & & & 4.82E-09 \\
\hline & WP018 & & & $3.22 \mathrm{E}-08$ & $5.06 \mathrm{E}-09$ \\
\hline & WP021 & 2.34E-08 & & 5.98E-08 & \\
\hline & WP023 & & 1.95E-08 & $1.27 \mathrm{E}-08$ & \\
\hline \multirow{9}{*}{2} & WP001 & & 1.35E-08 & 8.76E-09 & \\
\hline & WP003 & 8.48E-09 & & & 8.35E-09 \\
\hline & WP005 & $1.05 \mathrm{E}-07$ & & & 9.90E-08 \\
\hline & WP010 & $1.91 \mathrm{E}-08$ & & $1.48 \mathrm{E}-08$ & \\
\hline & WP011 & & & 5.39E-08 & 4.52E-08 \\
\hline & WP014 & $1.11 \mathrm{E}-08$ & & & $1.14 \mathrm{E}-08$ \\
\hline & WP018 & & & $1.21 \mathrm{E}-07$ & $1.29 \mathrm{E}-08$ \\
\hline & WP021 & 3.84E-08 & & 4.03E-08 & \\
\hline & WP023 & & 3.71E-08 & $1.54 \mathrm{E}-08$ & \\
\hline \multirow{9}{*}{3} & WP001 & & 2.01E-08 & $1.57 \mathrm{E}-08$ & \\
\hline & WP003 & 2.25E-08 & & & $1.22 \mathrm{E}-08$ \\
\hline & WP005 & 1.69E-07 & & & 1.23E-07 \\
\hline & WP010 & 2.62E-08 & & $1.64 \mathrm{E}-08$ & \\
\hline & WP011 & & & 8.37E-08 & 6.51E-08 \\
\hline & WP014 & 1.91E-08 & & & $1.05 \mathrm{E}-08$ \\
\hline & WP018 & & & 8.85E-08 & 2.05E-08 \\
\hline & WP021 & $5.26 \mathrm{E}-08$ & & 8.08E-08 & \\
\hline & WP023 & & 5.81E-08 & 4.43E-08 & \\
\hline \multirow{9}{*}{4} & WP001 & & 2.77E-08 & 2.23E-08 & \\
\hline & WP003 & $2.84 \mathrm{E}-08$ & & & $1.66 \mathrm{E}-08$ \\
\hline & WP005 & $1.04 \mathrm{E}-07$ & & & $1.10 \mathrm{E}-07$ \\
\hline & WP010 & 3.23E-08 & & 2.27E-08 & \\
\hline & WP011 & & & 8.48E-08 & $6.95 \mathrm{E}-08$ \\
\hline & WP014 & $1.85 \mathrm{E}-08$ & & & $1.24 \mathrm{E}-08$ \\
\hline & WP018 & & & 9.73E-08 & 3.32E-08 \\
\hline & WP021 & 4.62E-08 & & 7.19E-08 & \\
\hline & WP023 & & 8.80E-08 & $3.45 \mathrm{E}-08$ & \\
\hline \multirow{9}{*}{5} & WP001 & & 2.49E-08 & 2.09E-08 & \\
\hline & WP003 & $1.66 \mathrm{E}-08$ & & & $1.20 \mathrm{E}-08$ \\
\hline & WP005 & 9.55E-08 & & & $1.38 \mathrm{E}-07$ \\
\hline & WP010 & 2.57E-08 & & 2.31E-08 & \\
\hline & WP011 & & & 8.94E-08 & $6.84 \mathrm{E}-08$ \\
\hline & WP014 & 2.32E-08 & & & $1.21 \mathrm{E}-08$ \\
\hline & WP018 & & & 8.69E-08 & $2.04 \mathrm{E}-08$ \\
\hline & WP021 & $2.74 \mathrm{E}-07$ & & $1.01 \mathrm{E}-07$ & \\
\hline & WP023 & & 7.43E-08 & 3.28E-08 & \\
\hline
\end{tabular}


Table C-25. Effective Diffusivity $\left(D_{e, n}^{N a}\right)$ for Na $\left[\mathrm{cm}^{2} / \mathrm{s}\right]$

\begin{tabular}{|c|c|c|c|c|c|}
\hline Time Interval n & Saltstone Sample ID & Vial 1 & Vial 2 & Vial 3 & Vial 4 \\
\hline \multirow{9}{*}{6} & WP001 & & 1.99E-08 & $1.86 \mathrm{E}-08$ & \\
\hline & WP003 & 2.38E-08 & & & $1.42 \mathrm{E}-08$ \\
\hline & WP005 & 9.72E-08 & & & 7.97E-08 \\
\hline & WP010 & $3.28 \mathrm{E}-08$ & & 2.67E-08 & \\
\hline & WP011 & & & $5.44 \mathrm{E}-08$ & 5.57E-08 \\
\hline & WP014 & $2.28 \mathrm{E}-08$ & & & 1.96E-08 \\
\hline & WP018 & & & 9.77E-08 & 2.33E-08 \\
\hline & WP021 & 6.97E-08 & & $1.13 \mathrm{E}-07$ & \\
\hline & WP023 & & 9.29E-08 & $4.86 \mathrm{E}-08$ & \\
\hline \multirow{9}{*}{7} & WP001 & & $3.01 \mathrm{E}-08$ & $1.66 \mathrm{E}-08$ & \\
\hline & WP003 & 2.38E-08 & & & $1.60 \mathrm{E}-08$ \\
\hline & WP005 & $6.83 \mathrm{E}-08$ & & & $8.48 \mathrm{E}-08$ \\
\hline & WP010 & 2.09E-08 & & 3.02E-08 & \\
\hline & WP011 & & & 6.64E-08 & 2.05E-08 \\
\hline & WP014 & 2.30E-08 & & & 1.19E-08 \\
\hline & WP018 & & & 5.64E-08 & $2.49 \mathrm{E}-08$ \\
\hline & WP021 & 4.40E-08 & & 8.98E-08 & \\
\hline & WP023 & & 5.13E-08 & 4.09E-08 & \\
\hline
\end{tabular}


Table C-26. Effective Diffusivity $\left(D_{e, n}^{N a}\right)$ for $\mathrm{NO}_{3}{ }^{-}\left[\mathrm{cm}^{2} / \mathrm{s}\right]$

\begin{tabular}{|c|c|c|c|c|c|}
\hline Time Interval n & Saltstone Sample ID & Vial 1 & Vial 2 & Vial 3 & Vial 4 \\
\hline \multirow{9}{*}{1} & WP001 & & 4.67E-07 & 3.89E-07 & \\
\hline & WP003 & 1.09E-07 & & & $1.74 \mathrm{E}-07$ \\
\hline & WP005 & $2.18 \mathrm{E}-07$ & & & $2.34 \mathrm{E}-07$ \\
\hline & WP010 & 5.67E-07 & & 7.04E-07 & \\
\hline & WP011 & & & $1.12 \mathrm{E}-07$ & 1.65E-07 \\
\hline & WP014 & 3.39E-08 & & & $1.02 \mathrm{E}-08$ \\
\hline & WP018 & & & 9.55E-08 & 1.43E-08 \\
\hline & WP021 & $8.14 \mathrm{E}-08$ & & $1.73 \mathrm{E}-07$ & \\
\hline & WP023 & & $5.48 \mathrm{E}-08$ & 3.43E-08 & \\
\hline \multirow{9}{*}{2} & WP001 & & $8.27 \mathrm{E}-07$ & $1.01 \mathrm{E}-06$ & \\
\hline & WP003 & $1.20 \mathrm{E}-07$ & & & $2.01 \mathrm{E}-07$ \\
\hline & WP005 & $2.54 \mathrm{E}-07$ & & & $2.77 \mathrm{E}-07$ \\
\hline & WP010 & $1.46 \mathrm{E}-07$ & & $1.77 \mathrm{E}-07$ & \\
\hline & WP011 & & & 3.89E-08 & $5.26 \mathrm{E}-08$ \\
\hline & WP014 & 2.99E-08 & & & $2.75 \mathrm{E}-08$ \\
\hline & WP018 & & & 3.99E-07 & $3.63 \mathrm{E}-08$ \\
\hline & WP021 & $1.11 \mathrm{E}-07$ & & $1.21 \mathrm{E}-07$ & \\
\hline & WP023 & & $1.31 \mathrm{E}-07$ & 4.48E-08 & \\
\hline \multirow{9}{*}{3} & WP001 & & $6.91 \mathrm{E}-08$ & $6.22 \mathrm{E}-08$ & \\
\hline & WP003 & 7.62E-09 & & & 7.38E-09 \\
\hline & WP005 & $1.07 \mathrm{E}-08$ & & & $1.55 \mathrm{E}-08$ \\
\hline & WP010 & $<2.71 \mathrm{E}-10$ & & $3.45 \mathrm{E}-10$ & \\
\hline & WP011 & & & $3.96 \mathrm{E}-08$ & $3.62 \mathrm{E}-08$ \\
\hline & WP014 & $5.44 \mathrm{E}-08$ & & & 3.59E-08 \\
\hline & WP018 & & & 2.64E-07 & $5.85 \mathrm{E}-08$ \\
\hline & WP021 & $1.82 \mathrm{E}-07$ & & 2.43E-07 & \\
\hline & WP023 & & 1.93E-07 & $1.48 \mathrm{E}-07$ & \\
\hline \multirow{9}{*}{4} & WP001 & & $1.10 \mathrm{E}-08$ & $6.90 \mathrm{E}-08$ & \\
\hline & WP003 & 4.96E-08 & & & 9.39E-09 \\
\hline & WP005 & $1.21 \mathrm{E}-08$ & & & 2.05E-08 \\
\hline & WP010 & $1.00 \mathrm{E}-07$ & & 6.89E-08 & \\
\hline & WP011 & & & $2.75 \mathrm{E}-07$ & 2.15E-07 \\
\hline & WP014 & $5.50 \mathrm{E}-08$ & & & 3.27E-08 \\
\hline & WP018 & & & $2.90 \mathrm{E}-07$ & $9.26 \mathrm{E}-08$ \\
\hline & WP021 & $1.87 \mathrm{E}-07$ & & $2.22 \mathrm{E}-07$ & \\
\hline & WP023 & & $2.75 \mathrm{E}-07$ & $1.21 \mathrm{E}-07$ & \\
\hline \multirow{9}{*}{5} & WP001 & & $7.27 \mathrm{E}-08$ & 5.99E-08 & \\
\hline & WP003 & $4.82 \mathrm{E}-08$ & & & $3.58 \mathrm{E}-08$ \\
\hline & WP005 & $2.53 \mathrm{E}-07$ & & & 3.83E-07 \\
\hline & WP010 & 6.87E-08 & & $6.49 \mathrm{E}-08$ & \\
\hline & WP011 & & & $2.47 \mathrm{E}-07$ & $1.94 \mathrm{E}-07$ \\
\hline & WP014 & 5.95E-08 & & & $3.14 \mathrm{E}-08$ \\
\hline & WP018 & & & 2.33E-07 & 6.54E-08 \\
\hline & WP021 & $1.67 \mathrm{E}-07$ & & 3.34E-07 & \\
\hline & WP023 & & $2.26 \mathrm{E}-07$ & $1.02 \mathrm{E}-07$ & \\
\hline
\end{tabular}


Table C-26. Effective Diffusivity $\left(D_{e, n}^{N a}\right)$ for $\mathrm{NO}_{3}{ }^{-}\left[\mathrm{cm}^{2} / \mathrm{s}\right]$

\begin{tabular}{|c|c|c|c|c|c|}
\hline \multirow{4}{*}{ Time Interval n } & Saltstone Sample ID & Vial 1 & Vial 2 & Vial 3 & \multirow{2}{*}{ Vial 4 } \\
\hline \multirow{4}{*}{6} & WP001 & & $6.14 \mathrm{E}-08$ & $5.79 \mathrm{E}-08$ & \\
\cline { 2 - 6 } & WP003 & $7.30 \mathrm{E}-08$ & & & $4.19 \mathrm{E}-08$ \\
\cline { 2 - 6 } & WP005 & $2.73 \mathrm{E}-07$ & & & $2.24 \mathrm{E}-07$ \\
\cline { 2 - 6 } & WP010 & $9.66 \mathrm{E}-08$ & & $7.75 \mathrm{E}-08$ & \\
\cline { 2 - 6 } & WP011 & & & $1.69 \mathrm{E}-07$ & $1.71 \mathrm{E}-07$ \\
\cline { 2 - 6 } & WP014 & $6.31 \mathrm{E}-08$ & & & $5.64 \mathrm{E}-08$ \\
\cline { 2 - 6 } & WP018 & & & $2.97 \mathrm{E}-07$ & $6.53 \mathrm{E}-08$ \\
\hline & WP021 & $2.04 \mathrm{E}-07$ & & $3.56 \mathrm{E}-07$ & \\
\cline { 2 - 6 } & WP023 & & $2.89 \mathrm{E}-07$ & $1.37 \mathrm{E}-07$ & \\
\cline { 2 - 6 } & WP001 & & $7.38 \mathrm{E}-08$ & $4.48 \mathrm{E}-08$ & \\
\cline { 2 - 6 } & WP003 & $7.66 \mathrm{E}-08$ & & & $4.12 \mathrm{E}-08$ \\
\cline { 2 - 6 } & WP005 & $1.94 \mathrm{E}-07$ & & & $1.96 \mathrm{E}-07$ \\
\cline { 2 - 6 } & WP010 & $5.24 \mathrm{E}-08$ & & $7.27 \mathrm{E}-08$ & \\
\cline { 2 - 6 } & WP011 & & & $2.30 \mathrm{E}-07$ & $2.04 \mathrm{E}-07$ \\
\cline { 2 - 6 } & WP014 & $6.07 \mathrm{E}-08$ & & & $2.93 \mathrm{E}-08$ \\
\cline { 2 - 6 } & WP018 & & & $1.59 \mathrm{E}-07$ & $6.61 \mathrm{E}-08$ \\
\cline { 2 - 6 } & WP021 & $1.26 \mathrm{E}-07$ & & $2.77 \mathrm{E}-07$ & \\
\cline { 2 - 6 } & WP023 & & $1.36 \mathrm{E}-07$ & $1.32 \mathrm{E}-07$ & \\
\hline
\end{tabular}


Table C-27. Effective Diffusivity $\left(D_{e, n}^{N a}\right)$ for $\mathrm{NO}_{2}{ }^{-}\left[\mathrm{cm}^{2} / \mathrm{s}\right]$

\begin{tabular}{|c|c|c|c|c|c|}
\hline Time Interval n & Saltstone Sample ID & Vial 1 & Vial 2 & Vial 3 & Vial 4 \\
\hline \multirow{9}{*}{1} & WP001 & & $3.35 \mathrm{E}-07$ & $2.88 \mathrm{E}-07$ & \\
\hline & WP003 & $1.02 \mathrm{E}-07$ & & & 1.59E-07 \\
\hline & WP005 & 2.09E-07 & & & 2.18E-07 \\
\hline & WP010 & 5.21E-07 & & $6.41 \mathrm{E}-07$ & \\
\hline & WP011 & & & $1.00 \mathrm{E}-07$ & $1.49 \mathrm{E}-07$ \\
\hline & WP014 & 3.23E-08 & & & $<1.81 \mathrm{E}-08$ \\
\hline & WP018 & & & 9.12E-08 & $<1.39 \mathrm{E}-08$ \\
\hline & WP021 & 6.77E-08 & & $1.58 \mathrm{E}-07$ & \\
\hline & WP023 & & $5.26 \mathrm{E}-08$ & $3.46 \mathrm{E}-08$ & \\
\hline \multirow{9}{*}{2} & WP001 & & $6.27 \mathrm{E}-07$ & $7.58 \mathrm{E}-07$ & \\
\hline & WP003 & 1.13E-07 & & & $1.91 \mathrm{E}-07$ \\
\hline & WP005 & $2.44 \mathrm{E}-07$ & & & 2.59E-07 \\
\hline & WP010 & $1.54 \mathrm{E}-07$ & & $1.77 \mathrm{E}-07$ & \\
\hline & WP011 & & & 3.83E-08 & 4.95E-08 \\
\hline & WP014 & 2.79E-08 & & & 2.87E-08 \\
\hline & WP018 & & & 3.30E-07 & 3.20E-08 \\
\hline & WP021 & $1.05 \mathrm{E}-07$ & & 1.19E-07 & \\
\hline & WP023 & & $1.21 \mathrm{E}-07$ & $4.45 \mathrm{E}-08$ & \\
\hline \multirow{9}{*}{3} & WP001 & & $5.43 \mathrm{E}-08$ & $4.64 \mathrm{E}-08$ & \\
\hline & WP003 & 7.01E-09 & & & 6.59E-09 \\
\hline & WP005 & $<1.10 \mathrm{E}-08$ & & & 1.53E-08 \\
\hline & WP010 & $<9.06 \mathrm{E}-09$ & & $<$ 8.88E-09 & \\
\hline & WP011 & & & 3.56E-08 & 3.52E-08 \\
\hline & WP014 & $5.56 \mathrm{E}-08$ & & & 3.43E-08 \\
\hline & WP018 & & & 2.19E-07 & 4.81E-08 \\
\hline & WP021 & 1.63E-07 & & $2.16 \mathrm{E}-07$ & \\
\hline & WP023 & & $1.78 \mathrm{E}-07$ & $1.46 \mathrm{E}-07$ & \\
\hline \multirow{9}{*}{4} & WP001 & & $1.06 \mathrm{E}-08$ & $5.68 \mathrm{E}-08$ & \\
\hline & WP003 & 4.01E-08 & & & $<7.81 \mathrm{E}-09$ \\
\hline & WP005 & $2.18 \mathrm{E}-08$ & & & 2.87E-08 \\
\hline & WP010 & 8.63E-08 & & 6.10E-08 & \\
\hline & WP011 & & & $2.36 \mathrm{E}-07$ & $1.86 \mathrm{E}-07$ \\
\hline & WP014 & 5.61E-08 & & & 3.32E-08 \\
\hline & WP018 & & & 2.37E-07 & 7.47E-08 \\
\hline & WP021 & $1.64 \mathrm{E}-07$ & & $1.94 \mathrm{E}-07$ & \\
\hline & WP023 & & 2.43E-07 & $1.11 \mathrm{E}-07$ & \\
\hline \multirow{9}{*}{5} & WP001 & & $6.45 \mathrm{E}-08$ & 5.36E-08 & \\
\hline & WP003 & 4.06E-08 & & & $3.11 \mathrm{E}-08$ \\
\hline & WP005 & 1.77E-07 & & & 2.73E-07 \\
\hline & WP010 & 5.61E-08 & & 5.25E-08 & \\
\hline & WP011 & & & 1.97E-09 & $1.58 \mathrm{E}-09$ \\
\hline & WP014 & 5.99E-08 & & & $3.14 \mathrm{E}-08$ \\
\hline & WP018 & & & $1.91 \mathrm{E}-07$ & $5.26 \mathrm{E}-08$ \\
\hline & WP021 & $1.51 \mathrm{E}-07$ & & 2.77E-07 & \\
\hline & WP023 & & $1.96 \mathrm{E}-07$ & 9.99E-08 & \\
\hline
\end{tabular}


Table C-27. Effective Diffusivity $\left(D_{e, n}^{N a}\right)$ for $\mathrm{NO}_{2}^{-}\left[\mathrm{cm}^{2} / \mathrm{s}\right]$

\begin{tabular}{|c|c|c|c|c|c|}
\hline Time Interval n & Saltstone Sample ID & Vial 1 & Vial 2 & Vial 3 & Vial 4 \\
\hline \multirow{9}{*}{6} & WP001 & & 5.40E-08 & $5.25 \mathrm{E}-08$ & \\
\hline & WP003 & 6.12E-08 & & & 3.93E-08 \\
\hline & WP005 & $1.91 \mathrm{E}-07$ & & & $1.58 \mathrm{E}-07$ \\
\hline & WP010 & $7.72 \mathrm{E}-08$ & & $6.45 \mathrm{E}-08$ & \\
\hline & WP011 & & & $1.34 \mathrm{E}-07$ & $1.38 \mathrm{E}-07$ \\
\hline & WP014 & 6.01E-08 & & & $5.20 \mathrm{E}-08$ \\
\hline & WP018 & & & 2.39E-07 & 5.19E-08 \\
\hline & WP021 & $1.71 \mathrm{E}-07$ & & $2.97 \mathrm{E}-07$ & \\
\hline & WP023 & & $2.56 \mathrm{E}-07$ & $1.22 \mathrm{E}-07$ & \\
\hline \multirow{9}{*}{7} & WP001 & & $7.13 \mathrm{E}-08$ & $4.41 \mathrm{E}-08$ & \\
\hline & WP003 & $6.46 \mathrm{E}-08$ & & & 3.88E-08 \\
\hline & WP005 & 1.33E-07 & & & $1.38 \mathrm{E}-07$ \\
\hline & WP010 & 4.63E-08 & & $6.42 \mathrm{E}-08$ & \\
\hline & WP011 & & & $1.74 \mathrm{E}-07$ & $1.59 \mathrm{E}-07$ \\
\hline & WP014 & 5.51E-08 & & & 2.92E-08 \\
\hline & WP018 & & & $1.31 \mathrm{E}-07$ & 5.34E-08 \\
\hline & WP021 & $1.14 \mathrm{E}-07$ & & $2.35 \mathrm{E}-07$ & \\
\hline & WP023 & & $1.21 \mathrm{E}-07$ & $1.21 \mathrm{E}-07$ & \\
\hline
\end{tabular}

Now that the effective diffusivities for the $\mathrm{Cr}, \mathrm{Na}, \mathrm{NO}_{3}{ }^{-}$, and $\mathrm{NO}_{2}{ }^{-}$species for the various leaching time intervals $\left(D_{e, n}^{i}\right)$ for the Saltstone samples have been defined, the Leachability Index of each species $\left(\mathrm{L}_{\mathrm{i}}\right)$ can be calculated using Equation (3-2). 


\section{Distribution:}

\begin{tabular}{|l|l|}
\hline S. L. Marra & $773-A$ \\
\hline S. D. Fink & $773-$ A \\
\hline K. M. Fox & $999-\mathrm{W}$ \\
\hline B. J. Giddings & $786-5 \mathrm{~A}$ \\
\hline C. C. Herman & $999-\mathrm{W}$ \\
\hline F. M. Pennebaker & $773-42 \mathrm{~A}$ \\
\hline P. M. Almond & $773-43 \mathrm{~A}$ \\
\hline A. D. Cozzi & $999-\mathrm{W}$ \\
\hline R. E. Eibling & $999-\mathrm{W}$ \\
\hline E. K. Hansen & $999-\mathrm{W}$ \\
\hline C. A. Langton & $773-43 \mathrm{~A}$ \\
\hline D. H. Miller & $999-\mathrm{W}$ \\
\hline B. R. Pickenheim & $999-\mathrm{W}$ \\
\hline M. M. Reigel & $999-\mathrm{W}$ \\
\hline M. G. Serrato & $773-42 \mathrm{~A}$ \\
\hline D. B. Stefanko & $773-43 \mathrm{~A}$ \\
\hline P. R. Jackson & $703-46 \mathrm{~A}$ \\
\hline K. H. Subramanian & $249-8 \mathrm{H}$ \\
\hline J. M. Bricker & $704-27 \mathrm{~S}$ \\
\hline K. D. Dixon & $704-14 \mathrm{Z}$ \\
\hline J. N. Leita & $704-\mathrm{Z}$ \\
\hline K. R. Liner & $704-\mathrm{S}$ \\
\hline P. D. Mason & $704-14 \mathrm{Z}$ \\
\hline P. W. Norris & $704-29 \mathrm{~S}$ \\
\hline J.E. Occhipinti & $704-\mathrm{S}$ \\
\hline J. W. Ray & $704-\mathrm{S}$ \\
\hline S. C. Shah & $704-14 \mathrm{Z}$ \\
\hline D. C. Sherburne & $704-\mathrm{S}$ \\
\hline A. V. Staub & $704-27 \mathrm{~S}$ \\
\hline J. R. Tihey & $704-\mathrm{Z}$ \\
\hline H. H. Burns & $773-41 \mathrm{~A}$ \\
\hline T. W. Coffield & $705-1 \mathrm{C}$ \\
\hline D. A. Crowley & $773-43 \mathrm{~A}$ \\
\hline R. D. Freeman & $705-1 \mathrm{C}$ \\
\hline F. M. Smith & $705-1 \mathrm{C}$ \\
\hline K. H. Rosenberger & $705-1 \mathrm{C}$ \\
\hline & \\
& \\
\hline
\end{tabular}

